NBER WORKING PAPER SERIES

\title{
THE DYNAMICS OF RELIEF SPENDING AND THE PRIVATE URBAN LABOR MARKET DURING THE NEW DEAL
}

\author{
Todd C. Neumann \\ Price V. Fishback \\ Shawn Kantor \\ Working Paper 13692 \\ http://www.nber.org/papers/w13692
}

\author{
NATIONAL BUREAU OF ECONOMIC RESEARCH \\ 1050 Massachusetts Avenue \\ Cambridge, MA 02138 \\ December 2007
}

Our research has benefited from insightful comments from Daniel Ackerberg, Manuela Angelucci, Stephen Bond, Alfonso Flores-Lagunes, Claudia Goldin, Kei Hirano, Robert Margo, James Malcomson, Joseph Mason, Kris Mitchener, Ronald Oaxaca, Hugh Rockoff, John Wallis, Marc Weidenmeier, participants in sessions at the American Social Science Association meetings in San Diego in January 2004 and the NBER DAE Program Meeting in March 2004, and two anonymous referees. Funding for the work has been provided by National Science Foundation Grants SES-0617972, SES-0214483, SES-0080324, and SBR-9708098. Any opinions expressed in this paper should not be construed as the opinions of the National Science Foundation. Special thanks to Inessa Love for the use of her Panel VAR Stata program.

(C) 2007 by Todd C. Neumann, Price V. Fishback, and Shawn Kantor. All rights reserved. Short sections of text, not to exceed two paragraphs, may be quoted without explicit permission provided that full credit, including $(\mathrm{C}$ notice, is given to the source. 
The Dynamics of Relief Spending and the Private Urban Labor Market During the New Deal

Todd C. Neumann, Price V. Fishback, and Shawn Kantor

NBER Working Paper No. 13692

December 2007, Revised September 2009

JEL No. N0

\begin{abstract}
$\underline{\text { ABSTRACT }}$
During the New Deal the Roosevelt Administration dramatically expanded relief spending to combat extraordinarily high rates of unemployment. We examine the dynamic relationships between relief spending and local private labor markets using a new panel data set of monthly relief, private employment and private earnings for major U.S. cities in the 1930s. Impulse response functions derived from a panel VAR model that controls for time and city fixed effects show that a work relief shock in period t-1 led to a decline in private employment and a rise in private monthly earnings. The finding offers evidence consistent with contemporary employers' complaints that work relief made it more difficult to hire, even though work relief officials followed their stated policies to avoid affecting private labor markets directly. Meanwhile, negative shocks to private employment led to increases in work relief, consistent with Roosevelt's stated goal of using relief to promote relief and recovery.
\end{abstract}

Todd C. Neumann

University of California, Merced

P.O. Box 2039

Merced, CA 95344

and NBER

tneumann@ucmerced.edu

Price V. Fishback

Department of Economics

University of Arizona

Tucson, AZ 85721

and NBER

pfishback@eller.arizona.edu
Shawn Kantor

School of Social Sciences, Humanities and Arts

University of California, Merced

5200 N. Lake Road

Merced, CA 95343

and NBER

skantor@ucmerced.edu 


\section{Introduction}

The Great Depression of the 1930s remains the most serious economic disruption in U.S. history, with unemployment rates ranging from 10 to 25 percent throughout the decade (Darby 1976). After Roosevelt's resounding electoral victory in 1932, the federal government for the first time took major responsibility for providing relief assistance and offered billions of dollars in relief grants. The income assistance took two primary forms - work relief in which recipients were required to provide labor on public works projects, and direct relief which required no work obligation. The Roosevelt administration's stated goals were to provide income relief to the poor and the unemployed and to promote the recovery of the economy through investment in civil infrastructure and stimulus of consumer spending. Since work relief projects focused on building public works that had traditionally been the role of government, the hope was that private industry would be minimally affected. Moreover, the payments to work relief recipients per hour worked were typically well below the wages of those working in private jobs. Relief officials also encouraged workers to accept private employment when available. Despite these practices, private employers complained that WPA work relief made it more difficult for them to hire workers. ${ }^{1}$

The research to date on New Deal relief programs and their relationship with labor markets during the 1930s has come in three forms: narratives that describe how the programs worked, a large literature on the extent to which the geographic distribution of New Deal spending was used to offset prior unemployment and downturns, and attempts to assess the extent to which relief jobs crowded out private jobs. The narratives include Donald Howard's (1943) encyclopedic description of the workings of the Works Progress Administration (WPA), Jonathan Kesselman's (1978) detailed description of work relief programs in the context of a macroeconomic model, and Robert Margo's (1988) depictions of work relief using the 1940 Census with other scattered cross-sectional samples. ${ }^{2}$ Cross-sectional studies by Wright (1974), Fleck (1999a, 1999b), and Fishback, Kantor and Wallis (2003) show that more New Deal relief funds were distributed to areas with higher unemployment and deeper downturns in earlier periods. The published crowding-out studies include cross-sectional analyses by Robert Fleck

\footnotetext{
${ }^{1}$ See Howard (1940, 486-496), Coyle (1939), Brimhall (1937), Petree (8 November 1934, 15 April 1935, 12 November 1935,27 April 1936, 17 August 1936, 15 September 1936, 9 October 1936, 12 July 1937; and 13 September 1937), Larned (January 1935, 18 April 1935, 17 June 1935, 29 July 1935, 12 August 1935, 19 August 1935), Wood (12 April, 1937), and Works Progress Administration (1937).

${ }^{2}$ For other studies, see Bakke (1969 [1940]), Blumberg (1979), Brown (1940), McKean and Taylor (1955), Millett (1978), Schwartz (1984), Smith (2006), Walker (1979), Williams (1939).
} 
(1999a) of 1937 and 1940 unemployment statistics and Wallis and Benjamin's (1981) analysis of employment at the city level in 1934/1935. Both studies find no effect of relief assistance on private employment. Bernanke's (1986) time series study of employment in eight industries during the Depression finds that the presence of federal relief had no impact on labor markets. On the other hand, Wallis and Benjamin's (1989) unpublished study of employment in an annual panel of states suggests that an additional relief job contributed to a reduction of about half of a private job.

Most of the research to date has relied on cross-sectional data and thus can not capture the dynamic interactions between relief and private labor markets. We develop a new monthly panel dataset containing private employment, private earnings, and measures of direct and work relief spending in 44 cities during the 1930s. The data are then used to show the dynamic responses of the private labor market to changes in relief spending, while also revealing the dynamic responses of relief spending to increases in monthly earnings and/or greater levels of private employment. Private employment rather than measures of unemployment are the focus of the analysis for two important reasons. First, defining unemployment for the 1930s is complicated by the issue of whether people in work relief projects should be treated as employed or not (Darby 1976 and Fleck 1999a). Second, unemployment surveys were conducted only in 1930, 1937, and 1940, while the panel data set uses consistent monthly series for private employment from 1933 through 1939.

The analysis employs a panel vector autoregressive (VAR) model for several reasons. It fits the high frequency of the data; takes into account the persistence of employment, earnings, and relief spending across months; and shows the extent to which changes in relief spending might have led and or lagged changes in private labor markets. Finally, because we have Panel data we can control for unobserved time-invariant features of cities and national month-specific shocks. The coefficient estimates from the empirical model are used to graph impulse response functions (IRF) that illustrate how a one-month shock in WPA spending, for example, affected private employment and monthly earnings. Granger causality tests are also employed to identify the statistical significance of these relationships.

The impulse response functions show quite different relationships between relief spending and private labor markets during the First New Deal (through June 1935) and the Second New Deal (after December 1935). During the earlier period, which began as the 
economy approached its nadir, increases in total general relief spending (combined work and direct relief) were followed by increases in private employment and earnings, consistent with a view that relief spending served to stimulate the economy. During the Second New Deal, which came after two years of recovery, increases in direct relief were followed by increased private earnings and no significant effect on employment. On the other hand, increases in WPA work relief were followed by strong declines in private employment and increases in monthly earnings. This result helps explain confusion in discussions about the WPA during the Depression. In response to employers' complaints that WPA spending was making it more difficult to hire workers, WPA investigators provided evidence that the WPA encouraged its recipients to accept private employment. The results here suggest that the employer's complaints were real but could not be easily resolved by the actions of WPA administrators for the WPA spending created opportunities for workers that made it difficult for private employers to hire.

Finally, we show the extent to which relief spending responded to changes in labor markets and whether it was timed to increase as federal elections neared. Worsening conditions in local labor markets, it turns out, were followed by increases in relief spending. And the evidence suggests that increases in relief spending were roughly timed to rise during election years, and specifically during the late summer and early fall close to the election date in early November.

\section{Unemployment and New Deal Relief Institutions}

The 1930s recorded the highest level of unemployment in United States history. The official unemployment rate increased from 3.2 percent in 1929 to 15.9 percent in 1931 and then peaked at nearly one quarter of the work force in 1933. It remained above 20 percent through 1935 and above 14 percent through 1939 (Darby 1976). In response to this massive unemployment as well as other economic and financial panics, Roosevelt's New Deal in 1933 introduced the first targeted federal relief programs for the poor and unemployed.

Several different agencies contributed to the relief effort during the Depression. Between summer 1933 and June 1935 the Federal Emergency Relief Administration (FERA) provided grants to the states, which, in turn, distributed funds to local governments to make need-based payments to the unemployed either through direct or work relief programs. The payments that individual households received reflected the "budget deficit principle," which based the relief 
payment on the difference between the household's actual income and a standard household budget. Work relief required a recipient to perform work on a government project, while direct relief imposed no such requirements. Local relief agencies had the discretion to set their own FERA wages, which sometimes meant that limited relief budgets were spread relatively thinly so that more unemployed workers could be hired on relief projects. Worried about high unemployment and an anticipated harsh winter, the administration created the Civil Works Administration (CWA) in mid-November 1933. The agency employed up to four million people per week before it was terminated and many of the workers were then transferred to FERA projects in March 1934. Eligibility for the CWA was also based on the household budget deficit principle, although the CWA paid hourly wages similar to the wages paid by private contractors who were hired by the government to build public works. As a result, hourly CWA wages were substantially higher than the hourly relief wages on the FERA projects.

As part of a compromise associated with the enactment of the Social Security Act in 1935, there were several major shifts in the provision of relief. Full responsibility for direct relief was returned to state and local governments in the summer of 1935. Federal matching grants were offered to the states to help them run direct relief programs for old-age assistance, aid to the blind, and aid to dependent children. The federal government provided work relief directly through the Works Progress Administration for those considered "employable". Eligibility for WPA jobs was determined by local governments using the budget-deficit principle. WPA workers received hourly earnings that were roughly half those paid by private contractors working on government construction projects. ${ }^{3}$ If they lacked jobs, the employable were also eligible to receive direct relief (Kesselman 1978; Howard 1943; 200-207; Wallis, Fishback, and Kantor 2006), as were some WPA workers.

\section{The Interactions between Relief and Private Labor Markets}

Given the goals the Roosevelt administration had, its relief programs could interact with private labor markets in complex ways. Roosevelt's stated goals for his relief programs were to promote relief by providing basic aid to the unemployed and the poor and, in turn, to stimulate recovery as relief recipients spent the funds they received. The Roosevelt administration

\footnotetext{
${ }^{3}$ Wallis, Fishback, and Kantor 2006; Fleck 1999; Wallis 1989; Fishback, Haines, \& Kantor 2007. The Civilian Conservation Corps (CCC) and National Youth Administration (NYA) also provided work relief during the 1930s, but operated on a smaller scale than the WPA and had a much different focus. The Social Security Act also established Unemployment Insurance programs, but their impact was delayed in most states until the last two years of the decade in order to allow insurance funds to accumulate before payments were made.
} 
anticipated that the work relief jobs would boost consumer spending and thus increase demand for labor, which would then raise private employment and earnings. Fishback, Horrace, and Kantor (2005) find evidence that New Deal public works and relief spending did stimulate consumer spending. Their point estimate implies that spending an additional per capita dollar on New Deal relief and public works grants in a county during the period from 1933 through 1939 raised per capita incomes in 1939 by roughly 80 to 85 cents.

Even though relief and public works spending stimulated consumption, there remains the issue of whether they stimulated private labor markets or even crowded out private employment. The crowding-out argument suggests that the presence of work relief gave workers an extra outside option that allowed them to search less and to seek higher pay either in the form of larger wages or more hours in the private sector before accepting private employment. Higher pay would have induced private employers to reduce their demand for workers. The Roosevelt administration explicitly that they were trying to avoid adversely influencing private employment by focusing on public works projects traditionally built with government funds. ${ }^{4}$ Work relief projects certainly did not provide job opportunities for all of the unemployed. Darby's (1976) estimates of the shares of the labor force on work relief or fully unemployed suggest that roughly 4 to 7 percent of the labor force had work relief jobs, but the unemployment rate after subtracting out relief workers remained above 9 percent each year between 1931 and 1939.

It may seem surprising that work relief jobs would have been considered more attractive than private employment because the WPA paid substantially less per hour than most regular jobs (Sundstrom 1992, 1995). However, a worker facing a depressed economy also worried about job security, so the expected earnings for the year or month certainly turned on a worker's assessment of his unemployment risk (Kesselman 1978, 196-7). The risk of job loss in the private labor market during the Depression was high, while work relief jobs were viewed as relatively secure. A WPA mandate that workers continuously employed on projects for over 18

\footnotetext{
${ }^{4}$ See Federal Works Agency Works Projects Administration 1940, Kesselman 1978,, and Howard 1940, 124-126. In fact, the WPA occasionally was criticized for creating work and performing tasks for which there was no and never would be any demand such as "leaf-raking" in the forest (Congressional Record, June 16, 1939, p. 7294). Even though there was a focus on public projects, the WPA employment would have had effects on the labor markets for construction workers. To distribute aid to a larger relief population more quickly, the Roosevelt administration chose to pay relief workers low hourly earnings on the FERA and WPA public works projects during the 1930s (Clarke 1996, 62-68; Schlesinger 1958, 263-96). Generally, the workers were given a monthly stipend and their hourly earnings were determined by the number of hours they were required to work. This contrasts with the long-term practice, followed by the Public Works Administration (PWA), of hiring construction contractors who then hired their workers in the construction labor market.
} 
months be released from work relief was clearly not enforced because 16 percent of those on work relief in February 1936 remained employed continuously for 36 months through February 1939. In August 1939 the WPA dismissed over 750,000 persons who had exceeded the 18month limit, only to rehire 57 percent of them within the next year (Margo 1991, pp. 337-9; Federal Works Agency Works Projects Administration 1940). After several years of high unemployment, risk-averse workers may well have seen the WPA jobs as viable alternatives, despite the low hourly earnings. One WPA worker remarked, "Why do we want to keep these jobs? Well... we know all the time about persons on direct relief... just managing to scrape along... My advice, buddy, is better not take too much of a chance. Know a good thing when you got it."

In addition to the uncertainties of job loss in the private sector, a number of workers were "sharing" jobs in the sense that firms spread their limited amount of work to more workers who all worked relatively fewer hours. Such practices made the gap between private and work relief employment even smaller. Some contemporaries attributed job sharing to compassion, while others recognized that there were benefits to retaining workers with employer-specific skills in anticipation of a future upturn. ${ }^{6}$ The presence of more work relief jobs with rehire options gave employers an alternative to job sharing. They could off-load the less productive of the jobsharing workers on to the relief rolls, and then rehire them temporarily when business improved (in some cases while the worker still received WPA earnings). Workers moving back and forth between private employment and public relief may have been no worse off than under the prior job sharing arrangement. As a result, expansions in relief availability might have allowed jobsharing employers to reduce the number of people employed.

\section{The Political Economy and Timing of Relief Spending}

The issue of using relief spending for political purposes has generated even more academic controversy than the issue of crowding out. ${ }^{7}$ Contemporary critics claimed that Roosevelt had been trying to "buy" votes by timing increases in relief to coincide with impending elections. In both 1936 and 1938, the national WPA numbers showed all-time highs in WPA employment in October and November, followed by December declines. Critics also

\footnotetext{
${ }^{5}$ Quoted in E. W. Bakke, The Unemployed Worker (New Haven, 1940), pp. 421-22 and cited in Margo 1991 p.340.

${ }^{6}$ For contemporary policy statements on job sharing, see Walker (1933) and Moulton (1936).

${ }^{7}$ For example, see the large literature on the geographic distribution of funds summarized in Fishback, Kantor and Wallis (2003).
} 
sought to make political hay of autumn increases in 1940 (Howard 1943, 586-594). The controversy was particularly heated during the 1938 election. In late summer 1938 WPA director Harry Hopkins was alleged to have told his friends at a New York racetrack that the New Deal followed the following formula for success: "We shall tax and tax, spend and spend, and elect and elect." The statement was widely quoted, as newspapers disparaged the motives of Hopkins and the Roosevelt administration. Although Hopkins claimed that he never made such a statement, Smith $(2007,175-180)$ offers extensive evidence that he did (see also, McJimsey 1987, 124). Either way, the statement crystallized a cynical perception of the New Deal held by many critics and politicos.

Meanwhile the WPA's defense of the timing was that they were striving to offset unemployment caused by seasonality, droughts, and unusual periods of unemployment around the country. WPA officials argued that comparisons of WPA employment across states did not show higher than normal WPA employment in states where elections were tight (Howard 1943, 586-594). Gavin Wright's $(1974,35)$ cross-sectional regressions show that the number of per capita WPA jobs in December 1936 was higher in states that had a relatively higher number of jobs in January 1935, but also higher in states where there were more swing voters. He found similar results for a separate cross-sectional analysis of November 1940 WPA jobs as a function of 1937 unemployment rates.

\section{Data}

To analyze the effects of relief spending, we have compiled a new monthly panel data set of total spending on direct relief and work relief in 44 cities for the period January 1933 through December 1939. Using this data we construct a measure of total monthly relief spending (direct and work relief combined) by city between January 1933 and December 1939. For the period from December 1935 through December 1939 we were also able to develop separate monthly measures for direct and work relief.

To construct the total relief series, we combine monthly spending figures described as "General Relief" in the original source and WPA spending along with estimates of city level CWA spending from November 1933 through March 1934. "General Relief” in the original

\footnotetext{
${ }^{8}$ Total city level CWA spending is interpolated across months using state level monthly variation. See Appendix A for details. Because the CWA interpolations contain measurement error we will estimate several specifications, some of which do not include the CWA.
} 
source includes all FERA spending on direct relief and work relief plus nearly all state and local spending on their own relief programs throughout the period from January 1933 through December 1939. 9 The work relief portion of "General Relief” in the original source was typically about 43 to 50 percent after the end of the CWA in March 1934 until the introduction of the WPA in July 1935. ${ }^{10}$ The CWA and WPA spending in the original sources is all work relief. In the period after December 1935, total relief spending can be divided into separate estimates of work and direct relief because after this time the "General Relief" expenditures were nearly all for direct relief programs. Consequently, WPA spending accounted for all work relief spending during the period with the exception of a very small amount of FERA work relief listed under "General Relief” until March 1937. ${ }^{11}$ Relief expenditures are converted to per capita measures and then deflated by a city level consumer price index. We merge these data with city level private employment and private monthly earnings indices to create an unbalanced panel of monthly observations from 44 cities between 1933 and $1940 .^{12} 13$

There are a number of limitations to the assembled dataset that should be considered when interpreting our results. First the sample is not representative of all labor markets across the nation. The cities are for the most part larger urban areas. The smallest city has a population of approximately 62,000. Consequently one should interpret our results as how larger urban labor markets responded to relief spending. Thirteen states are represented, although California is the only southern or western state in the sample.

\footnotetext{
${ }^{9}$ In the original source "General Relief" is not available at the city level from January 1933-June 1933 or April 1937-November 1937. State monthly variation was used to predict these data. See Appendix A for details and discussion of the accuracy of predictions.

${ }^{10}$ The original source use of the term "General Relief" is unfortunate in that the term "general relief" was often and still is used to describe state and local government spending for relief of the poor who do not qualify for old age assistance, aid to dependent children, aid to the blind or work relief.

Local poor relief was not included during the period from 1933 through 1935, but was included afterward. Nationally, the extent of local poor relief consistently was about 1 to 2 percent of the general measure monthly from 1933 through 1935 . See WPA $(1942,41,384)$. The state and later state/federal "public assistance" programs for old-age assistance, mothers' pensions, and aid-to-the-blind are not included in general relief Examinations of Social Security Bulletin monthly statistics for these programs at the state level show that they tended to follow long run trends relatively closely and did not fluctuate from month to month nearly as much as general relief. Our sense from these statistics is that these public assistance programs were targeted at households with elderly, widowed mothers, and blind people who were not as closely connected to the labor market as the people on general relief. As a share of all types of relief public assistance was less than 8 percent from 1933 through 1936 . The share rose to 14 percent in 1937 as more states adopted the federal/state version of the program. The share rose to 17.6 and 23.7 in 1939 and 1940 as WPA spending declined. The shares above are calculated from annual data for 116 cities used in Fishback, Haines, and Kantor 2007.

${ }^{11}$ The "general relief" data in the original source after December 1935 is nearly all direct relief provided by state and local governments. FERA work relief spending accounted for between 0.5 and 1.5 percent of the "general relief" data after December of 1935 but before FERA was fully phased out in March 1937 (WPA 1942, 46).

${ }^{12}$ San Francisco, Los Angeles, Canton-OH, Cleveland, Cincinnati, Dayton, Columbus, Toledo, Youngstown, Akron, Syracuse, Rochester, Albany, Buffalo, New York City, Utica, Detroit, Baltimore, Lynn-MA, Lowell, Boston, Springfield-MA, Brockton, Cambridge, Fall River, Lawrence, Worchester-MA, Minneapolis, St. Paul, Duluth, Chicago, Springfield-IL, Kansas City-KS, Topeka, Wichita, Milwaukee, Kenosha, Racine, Philadelphia, Pittsburg, St. Louis, Jersey City, Newark, Trenton. The sample is unbalanced because employment data is unavailable for four cities prior to June of 1934 and unavailable after 1938 for 6 cities.

${ }^{13}$ A more detailed description of the data and sources is found in the Appendix A.
} 
Finally, the private labor market data for each city are based on "linked-relative" measures collected from surveys of a changing set of employers. We use this information to construct employment and earnings indices with June 1935 as the base. ${ }^{14}$ These linked-relative indices capture changes from one month to the next in the number of workers and the average monthly earnings of workers for the same set of private employers. Bernanke (1986) used similar data for industries from the National Industrial Conference Board in his analysis of fluctuations in employment and earnings across industries during the 1920s and 1930s. The problem with such data is that firm exit or entry can distort the magnitude of total changes. Under certain circumstances these indices may even misstate the direction of change in employment and earnings.

We have attempted to get a rough measure of the potential measurement error by comparing the annual averages for state level linked indices for manufacturing employment, constructed in the same way as our city estimates, to the annual average employment reported in the manufacturing censuses in the years 1933, 1935, 1937, and 1939. The correlations between the linked-relative state employment values and the annual average employment reported in the manufacturing censuses in the years 1933, 1935, 1937, and 1939 are 0.99 in California, 0.99 in Illinois, 0.40 in Kansas, 0.98 in Maryland, 0.45 in Massachusetts, 0.98 in Michigan, 0.86 in Minnesota, 0.99 in Missouri, 0.99 in New Jersey, .99 in New York, 0.98 in Ohio, 0.99 in Pennsylvania, and 0.923 in Wisconsin. ${ }^{15}$ A modern study by Pivetz, Searson, and Spletzer (2001) for the last quarter of 1999 offers some sense of the change in jobs in continuing firms relative to the change in jobs from entering and exiting firms. They find that changes in employment due to net entry and exit accounted for about 11 percent of the total change in jobs within continuing firms that is measured by the linked-relative index. ${ }^{16}$

Appendix D explores this issue in more detail by outlining under what conditions under-, over-, and mis-measurement can occur. We also present some Figures that illustrate the difference between the true and our measured linked-relative employment indices when the size

\footnotetext{
${ }^{14}$ Wallis (1989) offers tables with annual indices for employment by state from 1929 through 1940 using linked-relative indices for 1930s. For discussion of the modern equivalent to this data, see Krueger and Fortson (2003).

${ }^{15}$ The state establishment survey employment data we use for this comparison is the raw data that Wallis (1989) used to create his annual state level indices for the 1930s that we collected from data given to us by John Wallis and double-checked with the reports in various issues of the monthly publication Employment and Payrolls and the Monthly Labor Review. The data on state employment for the states came from the manufacturing census volumes during the 1930s (U.S. Bureau of Census, 1933, 1937, 1939, 1942). We could not benchmark the city linkedrelative indices because for most cities the employment reported was for all types of employment and the city data ran only from 1932 to 1939 and thus could not be matched to the 1930 and 1940 data for all employment.

${ }^{16}$ Total employment expanded from 108.2 to 109.2 million, a rise of 1 million jobs. During that span expanding establishments created 7.2 million jobs and contracting establishments destroyed 6.3 million jobs for a net gain of 0.9 million jobs. Meanwhile, opening establishments created 1.8 million jobs but closing establishments destroyed 1.7 million for a net gain of 0.1 million jobs.
} 
of unmeasured employment is on average 50 percent of measured, a much higher figure than found for 1999. Finally, we re-estimate one of our specifications assuming on average this size of unmeasured employment change. In general the patterns in the relationships between the private labor market and relief are not affected, but the size of responses can be over or under estimated depending on the type of measurement error. This should be considered when interpreting the results to follow.

\section{Correlations between Private Employment and Relief}

The Depression hit the entire country hard, but the extent of the downturn varied across locations. Similarly, the size of New Deal expenditures was unprecedented but also distributed unequally. Table 1 illustrates the cross-sectional variation of the six variables used in the paper by showing the means across the 44 cities and the standard deviation, minimum, and maximum of those means. For example, between July 1933 and December 1939, Brockton, Massachusetts received the highest average monthly per capita WPA spending of $\$ 2.19$ (All figures here and in Table 1 are real 1935 dollars constructed using city level Consumer Price Index for all items from the United States Bureau of Labor Statistics with June of 1935 as the base month).

Baltimore received the least at $\$ 0.27$. For the entire sample of 44 cities, the average monthly expenditure on WPA programs was $\$ 0.95$ per capita. The standard deviation of these means was $\$ 0.38$.

Table 1

Cross Sectional Summary Statistics

\begin{tabular}{cccccc}
\hline & $\mathrm{N}$ & Mean & Std & Minimum & Maximum \\
\hline Employment Index & 44 & 102 & 8 & 87 & 137 \\
Earnings Index & 44 & 104 & 9 & 51 & 114 \\
Total Relief Spending* & 44 & $\$ 1.85$ & $\$ 0.53$ & $\$ 0.88$ & $\$ 3.20$ \\
General Relief Spending per capita* & 44 & $\$ 0.78$ & $\$ 0.27$ & $\$ 0.33$ & $\$ 1.25$ \\
WPA Spending per capita* & 44 & $\$ 0.95$ & $\$ 0.38$ & $\$ 0.27$ & $\$ 2.19$ \\
CWA Spending per capita* & 44 & $\$ 0.12$ & $\$ 0.07$ & $\$ 0.02$ & $\$ 0.34$ \\
\hline *Real June 1935 Dollars & & & & &
\end{tabular}

In order to make the spending variables comparable with the labor market indices, we transform each city/month observation into that month's percent deviation from the city mean 
over the time period being estimated. ${ }^{17}$ Figure 1 charts on one graph the average deviations of Private Employment, Private Earnings, and the aggregated Relief measure. Labor market variables are indexed on the left hand axis and relief is indexed on the right.

Figure 1

Trends in Deviations from Mean Levels of Relief Spending and Private Labor Market Earnings and Employment (averaged across cities)

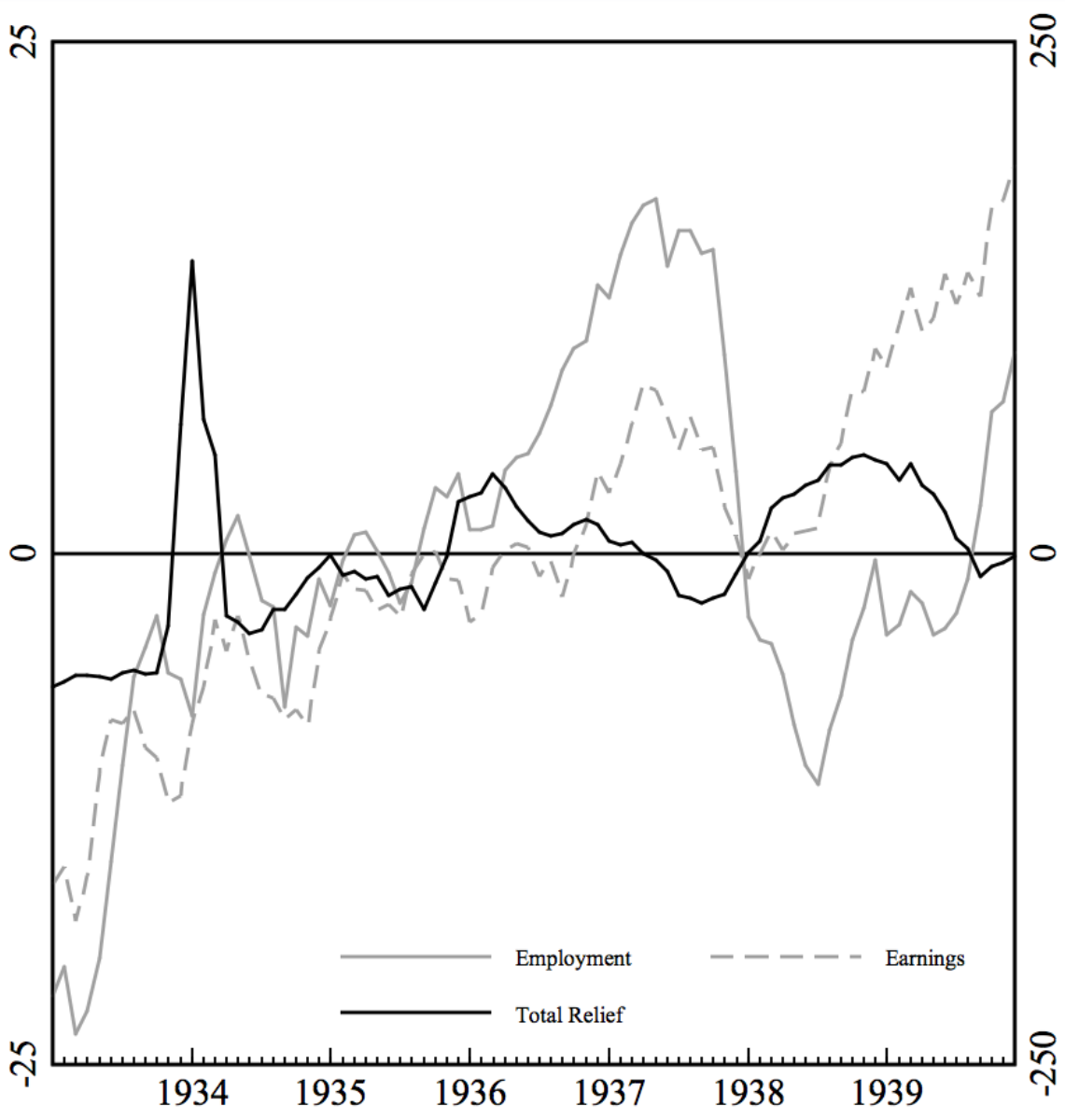

The spike in total relief in early 1934 is associated with the massive CWA work relief program. The CWA lasted only 4 months while employing over 4 million people at its peak and paying prevailing wages for up to thirty hours per week (Schwartz 1984, p. 117). ${ }^{18}$ After the Second New Deal policies were established in mid-1935, there were two peaks driven primarily by WPA spending, in mid-1936 and late 1938. The peaks in later periods fell well short of the

${ }^{17} Y^{d}=\frac{Y_{i t}-\bar{Y}_{i}}{\bar{Y}_{i}}$ Note that this eliminates any differences in the level of relief, employment, or earnings across cities.

${ }^{18}$ This spike is also more pronounced in our sample of cities than what one would see nationally because they received a disproportionately large portion of CWA spending compared with the national average. 
CWA peak in the winter of 1933-34 because the WPA never employed more than 3.2 million people and offered payments per hour worked that were roughly half of the CWA level (National Resources Planning Board 1942, 562-563). The smaller peak in 1935 is driven by the peak in First New Deal General Relief spending. Soon afterward the federal government returned responsibility for direct relief to state and local governments, and work relief was transferred to the WPA.

It is difficult to see any consistent correlation between the relief spending and the labor market earnings and employment. There is one striking rise in per capita relief spending in 1938/1939 that occurred at about the same time as a drop in employment. The relationship between the time paths of the average deviations across cities in private employment and earnings is also not clear. Over some periods it appears that increases in monthly earnings precede increases in employment. Since monthly earnings combine hours worked and wages, the pattern is consistent with employers following a practice of raising monthly hours before adding new employees.

We analyze our data using the VAR methodology. The data set meets the two major requirements for that methodology, comparability and stationarity. The use of per capita expenditures makes relief spending comparable across location, while taking the percent deviation relative to the mean of each variable makes the variation in relief spending comparable with variation in the private labor market variables. Each of these variables was also found to be stationary using a Fisher-type unit root test for panel data. ${ }^{19}$

\section{Empirical Model}

Consider an empirical model of the relationships between employment, monthly earnings, and the three relief programs like equation system (1) below.

$$
\begin{aligned}
& E m p_{i t}=\sum_{j=0}^{L} \alpha_{j}^{E m p} E^{E m p_{i t-j}}+\sum_{j=0}^{L} \alpha_{j}^{\text {Earn }} \operatorname{Earn}_{i t-j}+\sum_{j=0}^{L} \alpha_{j}^{\text {Relief }} \text { Relief }_{i t-j}+\varepsilon_{i t}^{E m p} \\
& \operatorname{Earn}_{i t}=\sum_{j=0}^{L} \beta_{j}^{\text {Emp }} \operatorname{Emp}_{i t-j}+\sum_{j=0}^{L} \beta_{j}^{\text {Earn }} \operatorname{Earn}_{i t-j}+\sum_{j=0}^{L} \beta_{j}^{\text {Relief }} \text { Relief }_{i t-j}+\varepsilon_{i t}^{\text {Earn }} \\
& \text { Relief }_{i t}=\sum_{j=0}^{L} \gamma_{j}^{\text {Emp }} \text { Emp }_{i t-j}+\sum_{j=0}^{L} \gamma_{j}^{\text {Earn }} \text { Earn }_{i t-j}+\sum_{j=0}^{L} \gamma_{j}^{\text {Relief }} \text { Relief }_{i t-j}+\varepsilon_{i t}^{\text {Relief }}
\end{aligned}
$$

\footnotetext{
${ }^{19}$ As developed by Maddala and Wu (1999).
} 
where $i$ indexes cities and $t$ indexes months. The endogenous variables are measures of period $t$ private employment $\left(E_{m p} p_{i t}\right)$, private earnings $\left(\right.$ Earn $\left._{i t}\right)$, and per capita relief spending (Relief $f_{i t}$ ). The model incorporates contemporaneous endogenous variables on the right hand side as well as several lags (up to L) for each variable in each equation. The lagged dependent variables account for the fact that in monthly data there is likely to be persistence of a variable like employment since employers often have a core group of workers that they retain even when laying off workers. Furthermore, the relationship between employment and another variable like relief might have lasted for several periods, as it took time for relief officials to recognize a drop in employment and additional time to take actions to expand relief. These same patterns were true for the other variables as well.

Estimation of the parameters of this empirical structural equation is made difficult because employment, earnings, and relief were likely determined simultaneously and endogenously. In a much simpler system with no lagged effects, estimating the coefficients effectively would require the development of instruments for each of the endogenous variables. Given the paucity of monthly data at the city level during the 1930s, finding such instruments is a daunting task. It is likely that any successful instrument strategy would not allow the estimation of the full lag structure in the system. ${ }^{20}$

An alternative strategy, which we employ; is to use a panel VAR model to explore the dynamic relationships between relief spending and the private labor market. Although we cannot estimate the underlying structural parameters in equation system (1), the VAR methodology has several advantages. It does not require any a priori assumptions on the direction of feedbacks between the variables in the model. Instead, all current period measures of relief and the private labor market are allowed to be a function of the past values of each other. This allows us to estimate, for example, the total reduced-form effect that a past increase in work relief had on each of the other dependent variables and how those changes moved through the local economy over time. The structure of the panel VAR is found in equation system (2).

\footnotetext{
${ }^{20}$ We considered the use of an Arellano-Bond strategy of using lagged levels of the dependent variable as instruments for differenced dependent variables. However, Stephen Bond informed us in correspondence that he considered 44 cross-sectional observations to be too small a sample for effective use of the technique.
} 


$$
\begin{aligned}
& E m p_{i t}=\sum_{j=1}^{L} a_{j}^{E m p} \operatorname{Emp}_{i t-j}+\sum_{j=1}^{L} a_{j}^{\text {Earn }} \operatorname{Earn}_{i t-j}+\sum_{j=1}^{L} a_{j}^{\text {Relief }} \operatorname{Relief}_{i t-j}+e_{i t}^{\text {Emp }} \\
& \operatorname{Earn}_{i t}=\sum_{j=1}^{L} b_{j}^{\text {Emp }} \operatorname{Emp}_{i t-j}+\sum_{j=1}^{L} b_{j}^{\text {Earn }} \operatorname{Earn}_{i t-j}+\sum_{j=1}^{L} b_{j}^{\text {Relief }} \operatorname{Relief}_{i t-j}+e_{i t}^{\text {Earn }} \\
& \text { Relief }_{i t}=\sum_{j=1}^{L} c_{j}^{\text {Emp }} \operatorname{Emp}_{i t-j}+\sum_{j=1}^{L} c_{j}^{\text {Earn }} \text { Earn }_{i t-j}+\sum_{j=1}^{L} c_{j}^{\text {Relief }} \operatorname{Relief}_{i t-j}+e_{i t}^{\text {Relief }}
\end{aligned}
$$

In estimating the coefficients in equation system (2), the panel VAR allows us to treat the past values of the variables as exogenous for several reasons. Since the equations are current values as functions of past values, the simultaneity of the system is eliminated. Potential problems with serial correlation in the errors of each equation are eliminated by incorporating an appropriate number of lags for each variable. Transforming the data into deviations from the city level mean eliminates any time-invariant factors (such as structural features of the city's economy and political environment) that might have been correlated with both relief spending and the private labor market. In addition the panel nature of the data allows us to control for national monthly shocks. ${ }^{21}$ These would include seasonal factors that influenced employment patterns, national economy-wide shocks like the move away from the gold standard or changes in federal tax rates, the timing of elections, and shocks to relief associated with the timing of Congress's approval of new federal budgets for relief, or changes in the federal relief program's rules.

\section{Specifications}

We consider three specifications in the text. Specification 1 uses the combined relief measure (both work and direct relief) and covers the entire period from January 1933 through December 1939. We created specifications 2 and 3 to see whether changes in the organization of the relief programs or the period under consideration make a significant difference in the results. General relief spending changed substantially after June 1935 when the WPA took over work relief and the FERA was being phased out. In Specification 2, which runs from January 1933 through June 1935 we examine the separate effects of the CWA work program, which paid close to private market wages, and the General Relief program, which included both FERA work relief

\footnotetext{
${ }^{21}$ The impulse response results are estimated using STATA code written by Inessa Love of the World Bank. For these estimates the data are demeaned by month, eliminating the time specific national shocks. We test the time demeaned data used for estimating the impulse responses to be sure the demeaning has not reintroduced city level fixed effects.
} 
and direct relief from all levels of government. Specification 3, which runs from January 1936 through December 1939, takes up the effects of direct relief, and the WPA, which was exclusively a work relief program. We leave the period from July through December 1935 out of Specifications 2 and 3 because this was a period of transition. ${ }^{22}$ To probe the robustness of these results, we have also estimated several other specifications that are reported and briefly discussed in Appendix C. ${ }^{23}$ The conclusions reached from these results are very similar to what we report in the text.

\section{Lag Length}

To insure the consistency of the reduced-form VAR coefficient estimates, two criteria are used to determine the appropriate lag structure. The first criterion selects the lag length that minimizes one of two measures of goodness of fit. The measures trade off the complexity of an estimated model against how well the model fits the data. A lag of five months minimizes the value of the Akaike information criterion (AIC) and a lag of 8 minimizes the Bayesian information criterion (BIC). ${ }^{24}$ While the specification criteria would indicate as few as 2 lags might be appropriate, we examine a second criterion, cross-correlations in the estimated residuals in order to assure that the innovations are not autocorrelated with one another over time. After checking different lag lengths we settle on nine. Table B.3 of the Appendix reports the number of statistically significant cross-correlations for lags of up to 19 periods for each specification. In all cases fewer than 7 percent of the cross-correlations were statistically different from zero. ${ }^{25}$

\section{Results}

Each specification entails the estimation of between 81 and 225 coefficients. As is common in VAR analysis, the discussion of the results focuses on Impulse Response Functions (IRFs) that are derived from the coefficients, which are reported in Appendix B. The statistical

\footnotetext{
${ }^{22}$ FERA work relief declined continuously from 44.7 percent of general relief in July 1935 to below 2 percent in January 1936 (WPA 1942, 38). It then stayed below that level until FERA was fully phased out in March 1937. In the results reported in the text, this period is included on the right hand side as lags. For robustness we further restricted the model so that no lags prior to January 1936 were included. This reduced the number of observations but had virtually no affect on the IRFs, Granger Causality tests, or coefficient results. Consequently we stuck with using January 1936 as the starting point of the analysis reported in the text.

${ }^{23}$ The specifications show the results associated with examining the separate effects of General Relief, the CWA, and the WPA in an estimation that covers the entire time period and the robustness of the results when we remove the CWA measure, which contains some measurement error because we interpolate monthly values using state information.

${ }^{24}$ Information Criteria presented in Table B.2 of the Appendix are from Specification 1. For other specifications the suggested appropriate lag length never exceed 7.

${ }^{25}$ Because 9 lags are employed when we say a specification runs from 1933 through the end of 1939 this means the actual first period used as a dependent variable is October 1933 with the previous 9 months of 1933 used as lag dependent variables.
} 
significance of one variable's ability to explain another is examined through a series of Granger Causality tests from each specification. The Granger causality test compares the fit of the model before and after restricting the coefficients on a given variable's lags to zero. If the null is rejected, the excluded variable is said to influence or "Granger-cause" the dependent variable. Table 2 reports the p-values, the statistical confidence levels for Type I error, from the test that the lagged values of a given variable can be excluded from an equation. Across every specification the private monthly earnings and private employment variables can be said to Granger-cause one another at a confidence level of 5-percent or better.

In Specification 1 the aggregated relief measure Granger-causes employment and earnings at significance levels of less than 1-percent and 11-percent, respectively. Meanwhile, the aggregated relief measure is Granger-caused by private employment at better than the 0.1 percent significance level.

Specifications 2 and 3 split the decade into the First and Second New Deal to examine the separate impacts of different kinds of relief. Specification 2 shows that General Relief, which includes both work and direct relief during the First New Deal, does not Granger-cause private employment or earnings at any meaningful level. Meanwhile, private employment Grangercauses general relief at the 0.1 -percent. The CWA Granger-causes private employment and earnings at the 1-percent and 5 percent levels respectively. 
Table 2

Granger Causality Tests

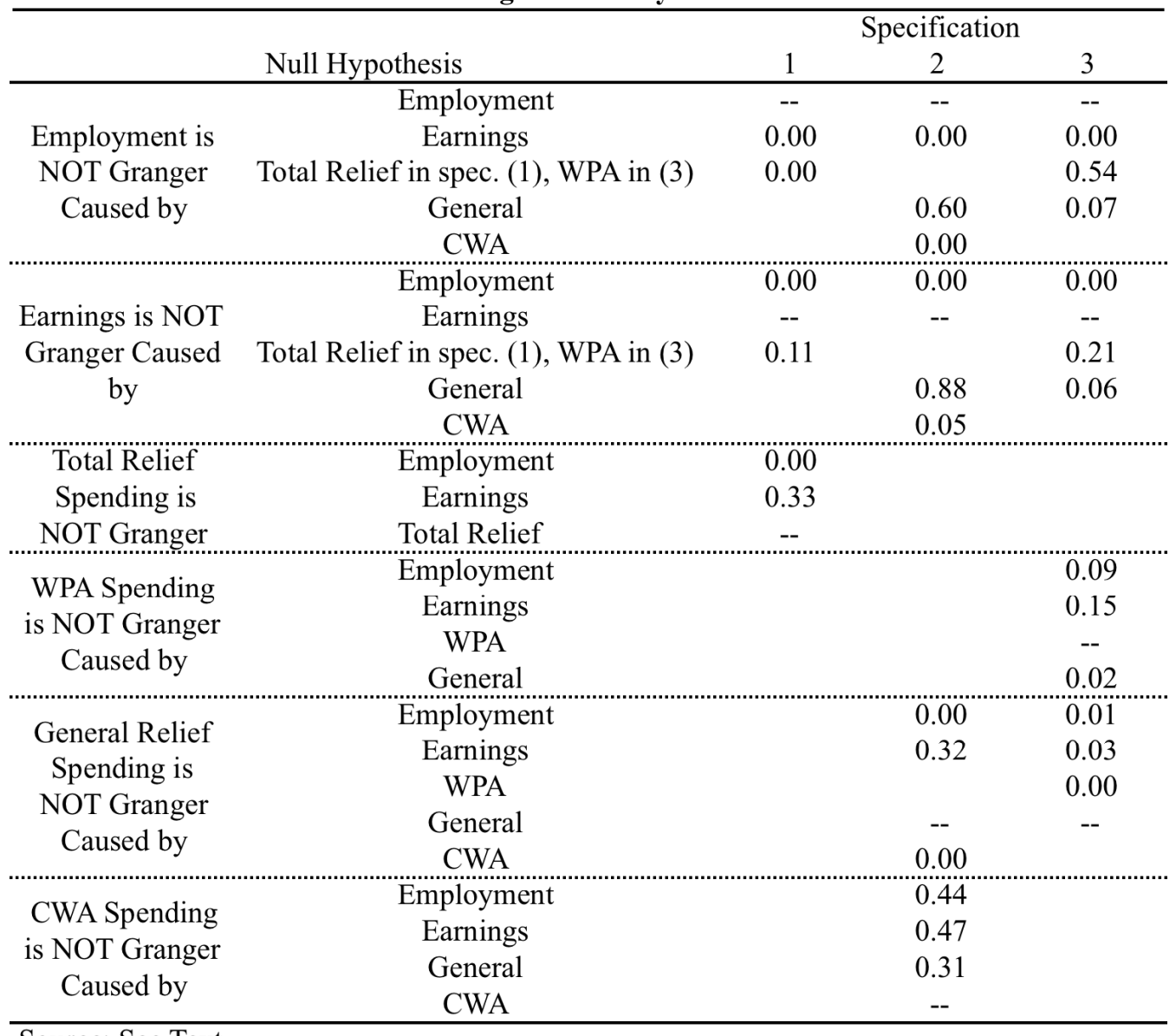

Source: See Text

Note: numbers indicate the p-value of the test of each null hypothesis by specification. For example under Specification 2 we can only reject the null hypothesis that employment is not Granger caused by General relief at a significance level of 60 percen

In Specification 3, where we can examine the differences between work relief and direct relief most clearly, private earnings and employment are estimated to have Granger-caused WPA work relief spending at the 9- and 15-percent levels. However, neither of the private labor market variables is Granger-caused by WPA work relief at any significance level below 21 percent. Meanwhile, there is Granger causation at the 7-percent significance level or better in both directions between direct General relief and each of the private labor market variables. WPA spending and direct relief had Granger-causal relationships at the 2-percent level or better in both directions. 


\section{Impulse Response Functions}

The dynamic relationships estimated in the panel VAR are best illustrated by graphing Impulse Response Functions (IRFs). Figures 2, 3, and 4 chart the responses to a one-month, one-standard-deviation positive shock in period zero (here after referred to simply as a shock) over the following three-year period. The units on the vertical axis show the dependent variable's percent deviation from its mean in each month. The dark line is the point estimate of the IRF, and the dotted lines show the $90 \%$ confidence interval around that estimate, created using bootstrap standard errors with one thousand repetitions. The IRF figures illustrate the patterns of the responses but it is more difficult to use them to get a sense of the magnitude of these responses for two reasons. First, because the deviations are measured as a percent of a variable's mean, dollar for dollar or job for job comparisons are not obvious. Second, the deviation shows how a variable is affected in a given month. One is also likely interested in knowing how much employment, for example, responded in total over the course of 3 years to a certain size increase in say relief over that same 3 year period. In order to make these calculations we will also compare the cumulative deviations, roughly equivalent to the area between the impulse response function line and the zero line.

Figure 2 presents the results from Specification 1 that aggregated all relief spending from the different programs into a single variable. The response of employment to a shock in relief (row 1 and column 3 of Figure 2) was erratic with an initial tiny decline, a tiny rise and then a sharp drop of nearly 0.4 percent by month 4 before returning to approximately zero by month 6 , then dropping again through month 9 before trending back towards zero for the remainder of the time. The one-standard deviation one-month shock to relief spending resulted in a cumulative increase in relief spending of 89 percent of the average and a cumulative decrease in employment of 2.4 percent. For a city like Cleveland with average monthly relief spending of $\$ 2,700,000^{26}$ during this time period, the one month shock would have led to feedbacks and responses that ultimately raised relief spending by $\$ 2,400,000$ over three years. Cleveland had an average employment of around 450,000 workers, so the cumulative decreases would have

\footnotetext{
${ }^{26}$ June 1935 dollars.
} 
reduced employment 10,800 job months over this period. ${ }^{27}$ This translates to approximately $\$ 220$ per job month. ${ }^{28}$

Figure 2

Impulse Responses to a one standard deviation positive shock at time zero--Specification 1
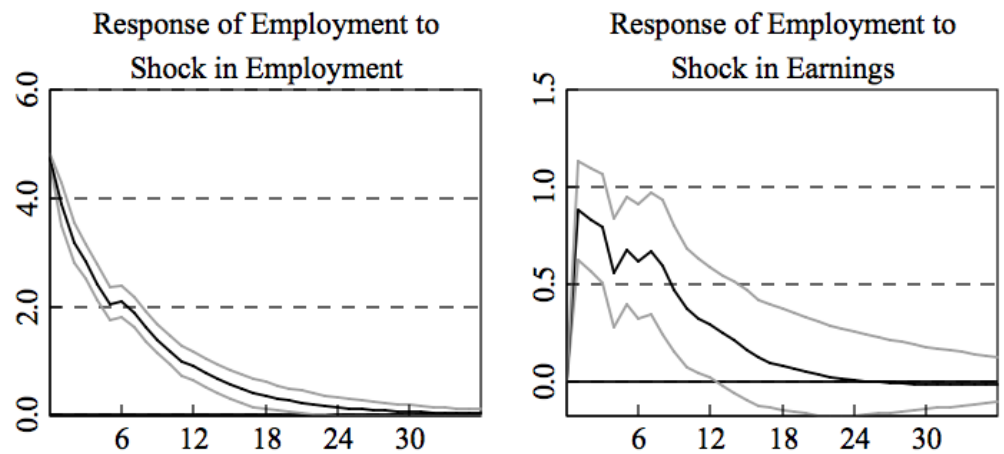

Response of Employment to
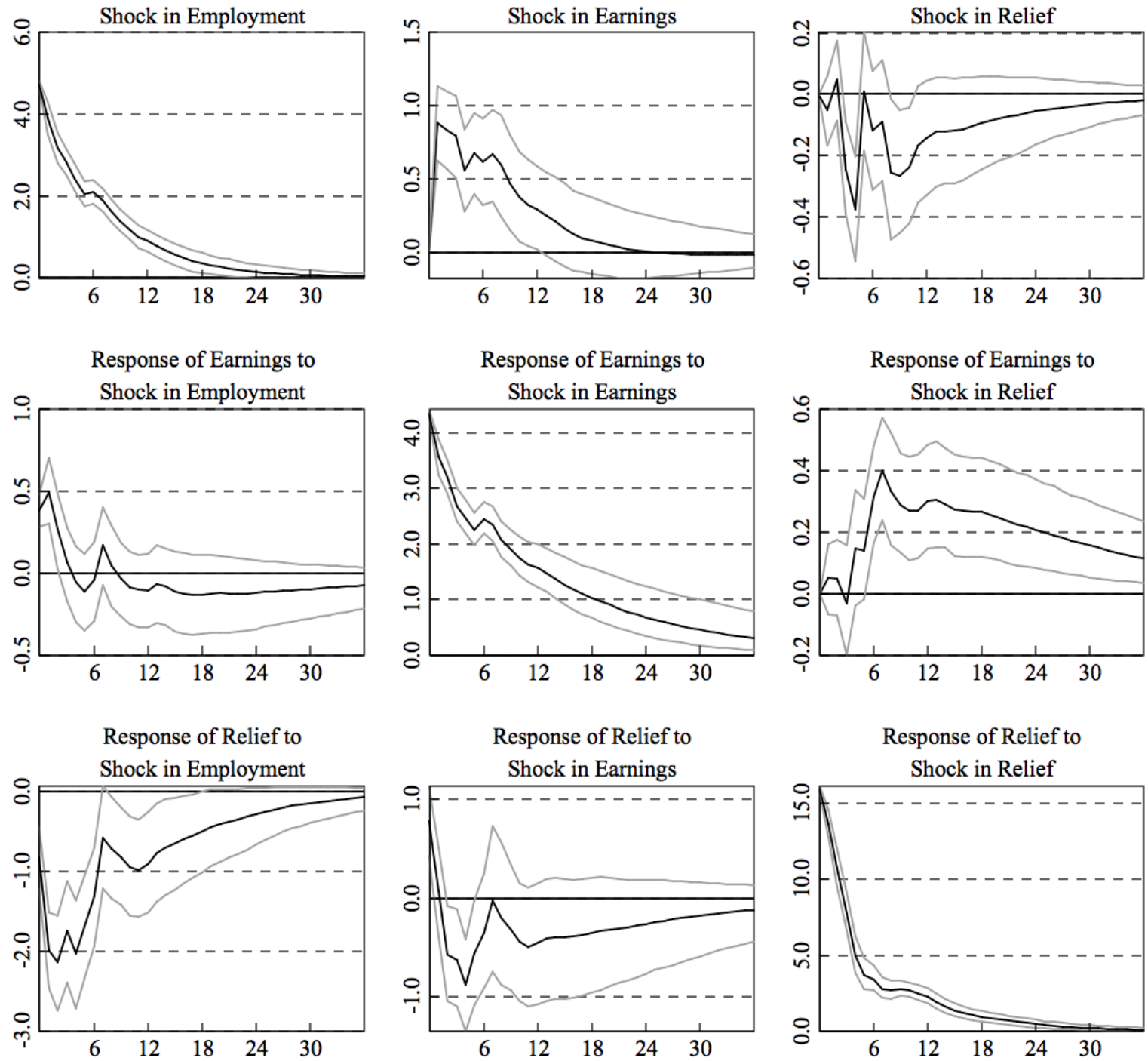

Months after Shock

Source: See Text

The response of private earnings to a shock in relief (row 2 and column 3 of Figure 2) is stronger and more positive than the response of private employment. If we again use Cleveland

\footnotetext{
${ }^{27}$ Cleveland had a population of 1.2 million. Assuming a labor force participation rate of $46.6 \%$ and an average unemployment rate of $20 \%$, the employed population would have been 448,276 .

${ }^{28}$ It is important to note that these magnitudes especially for employment should be considered rough estimates of the true relationship since the labor market variables are derived from linked relative indices.
} 
as an example, approximately six to nine months after the increase in relief expenditures, private earnings reach a level approximately 0.4 percentage points (41 cents in Cleveland if the Ohio average of $\$ 102$ a month is used) from the mean and stay nearly 0.2 percentage points (20 cents in Cleveland) higher for the remainder of the period. The cumulative increase in private earnings would have been 8.4 percent of a month's earnings, or a total gain in earnings of $\$ 8.57$ per worker in Cleveland over the period. Since monthly earnings are the product of average hourly earnings and hours worked per month, monthly earnings may have increased either because hours rose or hourly wage rates increased.

Figure 2 suggests that relief spending and the private labor market interact in a dynamic way, particularly when it comes to the effect of relief spending on private monthly earnings. It is true that the results from specification 1 should be considered with caution since the specification assumes that direct and work relief had the same relationship with the private labor market. Specification 1 also assumes that the dynamics are the same across the entire Depression. In the next two specifications, the estimation is broken into two periods to explore how changes in the relief programs may have influenced things. The First New Deal period through June 1935 in specification 2 offers an opportunity to examine the impact of relief during the deepest trough of the Depression, when unemployment exceeded 20 percent and businesses and labor were operating under the National Recovery Administration agreements designed to raise wages and prices. The Second New Deal period from July 1935 through December 1939 in specification 3 makes it possible to probe the separate effects of work relief (in the form of WPA spending) and direct relief (in the form of state and local direct relief spending). ${ }^{29}$

The IRFs from specifications 2 and 3 show quite different dynamics by program and time period. The relief shocks in specification 2, which combine work and direct relief from the FERA and the state and local governments, were followed by rises in employment and earnings. As before, the magnitude of the private labor market's response to a shock in relief spending is gauged by comparing the cumulative changes.

A shock to General relief spending in specification 2 resulted in a cumulative increase in relief spending of 41 percent of the average and a cumulative increase in employment and earnings of 0.58 percent and 1.6 percent, respectively. For a city like Cleveland with average General relief spending of $\$ 1,467,000$ per month prior to July 1935 , the one-month shock would

\footnotetext{
${ }^{29}$ Note, because 9 lags are used in the specification the first period used as the dependant variable is April 1936. We also estimated specification 3 using January 1936 as the earliest lagged variable and October 1936 as the earliest dependent variable. IRF's were nearly identical.
} 
have led to feedbacks and responses that ultimately raised relief spending by $\$ 600,000$. Given Cleveland's average expenditure per case of $\$ 26.50$ in this time period, the rise in relief spending would have provided aid for roughly an additional 22,600 case-months over three years.

Figure 3

Impulse Responses to a one standard deviation positive shock at time zero--Specification 2
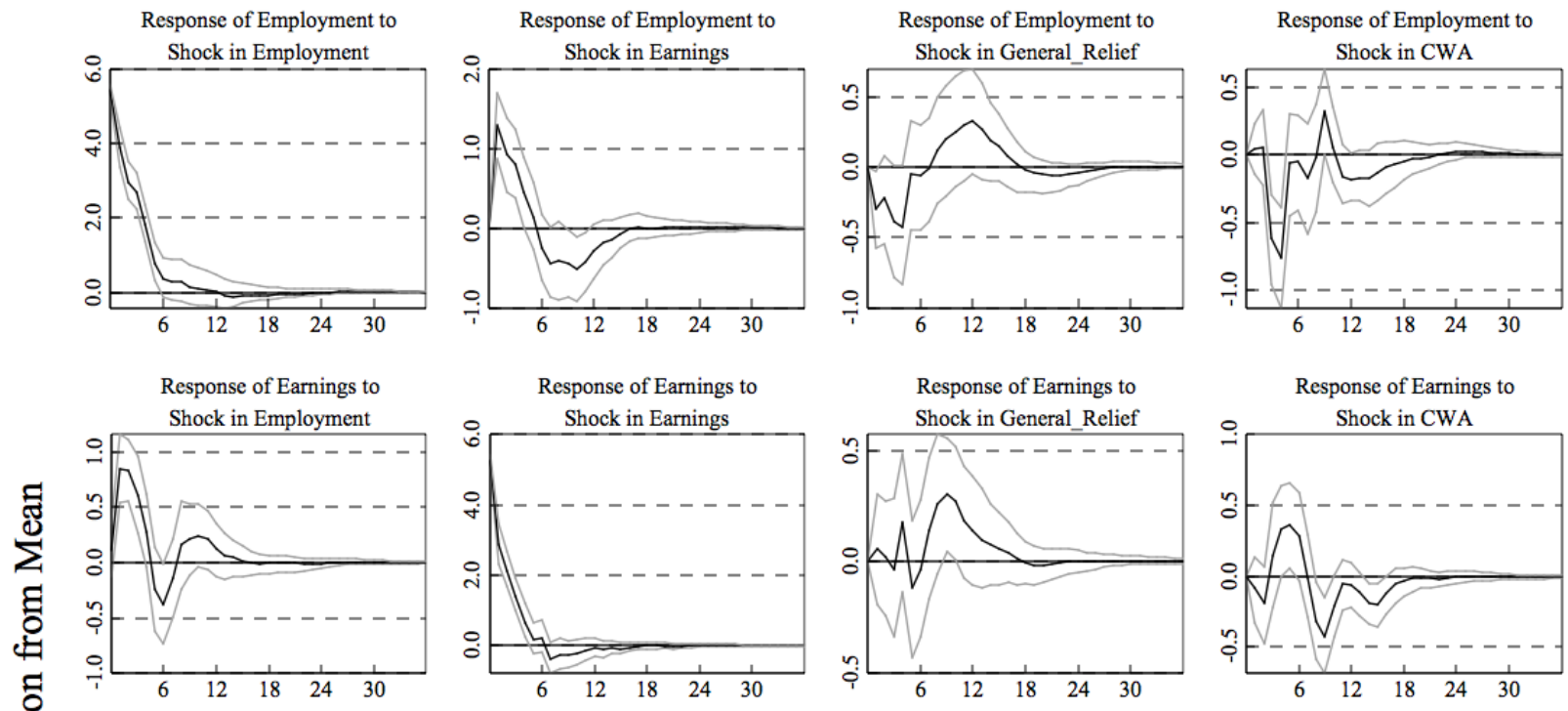

Response of General_Relief to

Shock in Employment
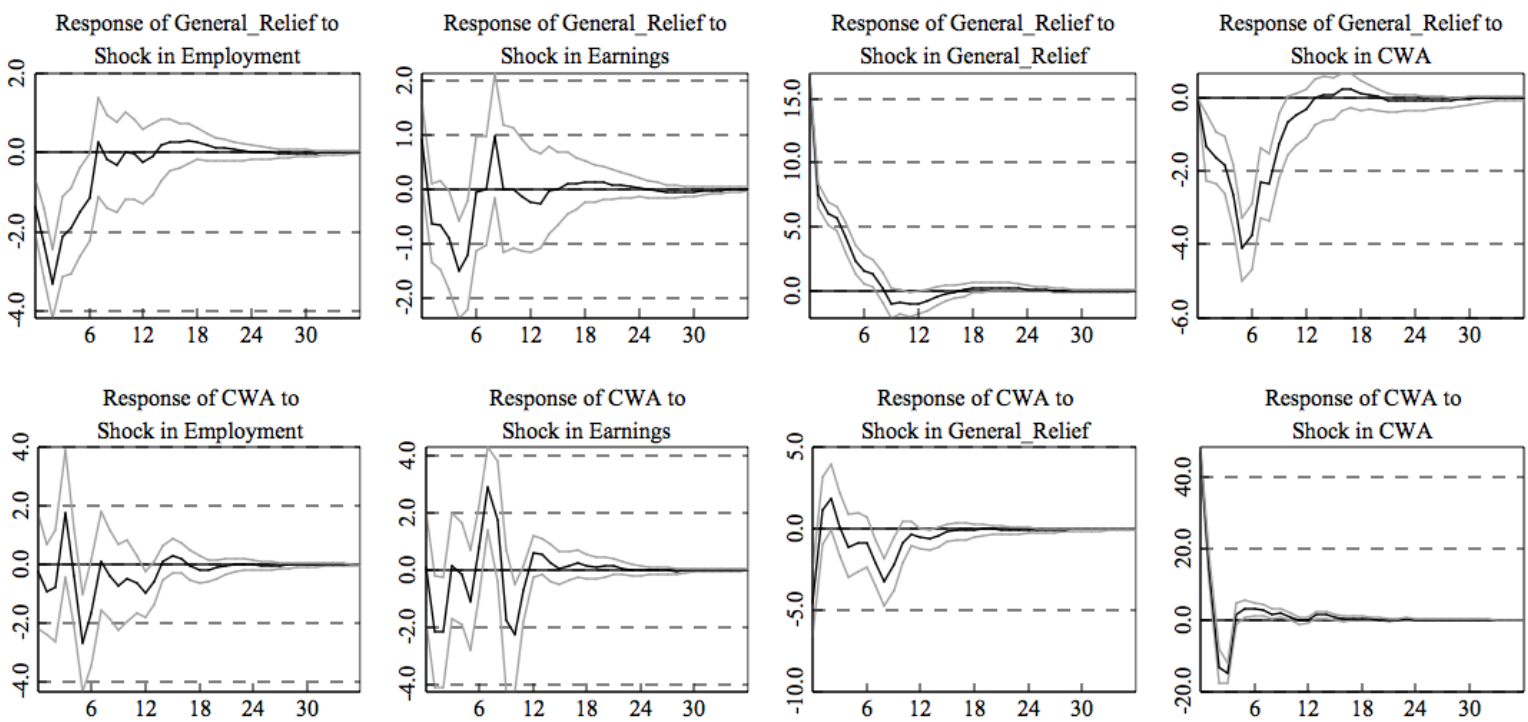

Months after Shock

Source: See Text

Given that Cleveland had an average employment of around 450,000 workers, the cumulative rise in employment of 0.58 percent that would have followed would have added approximately 2,600 job months above the mean over the 36 -month period. This suggests that 1 
additional private job month was added for each additional \$230 in relief spending or each 8.6 additional relief case-months. A similar calculation suggests that an additional job month would require 7.1 and 6.7 case months in Los Angeles and New York respectively.

A general relief shock also was followed by a monthly earnings increase that had little effect for 6 months before rising to 0.3 percent in the latter half of the first year and remaining quite high for several months thereafter (see row 2 and column 3 of Figure 3). Using the Ohio's average monthly wage of 102 dollars for Cleveland, the 0.3 percent increase in monthly earnings in the latter half of the first year would have been an extra 31 cents for that month. The cumulative increase of a 1.6 percent deviation from the mean in private earnings would have amounted to a total of 1.63 additional dollars paid out over 36 months of extra earnings for a typical worker.

Since the CWA lasted for only 5 months, it should not be surprising that a shock to CWA spending led to virtually no sustained increase in CWA spending (row 4 column 4 of Figure 3 ). A one-standard deviation shock to CWA spending per person was followed by decrease in employment that bottomed out in 5 months at about 0.76 percent (row 1 column 4 of Figure 3 ). The response of private earnings fluctuated sharply within the first eight months. An initial small drop was followed by a rise to a nearly 0.4 percent deviation from the mean, which was followed by a drop to a nearly 0.5 percent deviation from the mean before falling back to zero by the $18^{\text {th }}$ month. On net, over the 3 years after a shock to the CWA spending both employment and private earnings would have had cumulative decreases of 2.2 and 1.0 percent respectively. In Cleveland, this would have meant a cumulative decrease in employment of 9,900 job months and cumulative lower earnings payments of 1.02 dollars over three years for a typical worker. ${ }^{30}$

Specification 3 for the Second New Deal from June 1935 through December 1939 offers the only opportunity to separately examine the impact of work relief provided by the WPA and direct relief, which was provided by state and local governments from 1936 to 1939 and by the FERA as it was phasing out through March 1937.

\footnotetext{
${ }^{30}$ We do not discuss the dynamic responses of the CWA to private labor markets for two reasons. First, the program lasted only four months; therefore, there was little opportunity for the CWA to respond to changes in the private labor market. Second, we have city-level information on the four-month total for the CWA. To allow us to avoid omitted variable bias in the estimates for General relief we interpolated the monthly spending for each city using the state level variation in the timing of CWA spending. Consequently conclusions drawn from these IRFs about the response of the CWA program should be viewed with caution. As a check to assure that the inclusion of this variable does not alter the conclusions drawn about the General relief Specification 6 excludes the CWA variable. In essence, we are reducing the impact of measurement error in the CWA on the estimates for FERA, but increasing the potential for omitted variable bias. The results are nearly identical and can be viewed in the appendix.
} 
A one-standard deviation increase in direct relief spending was followed by a cumulative increase in direct relief over the 3-year period of 58 percent (row 3 column 3 of Figure 4). For a city like Cleveland that had average direct relief spending during this period of approximately 720,000 dollars per month the cumulative increase would have been 418,000 dollars over the 3year period. The shock to direct relief is followed by a decrease, then increase in private employment. The cumulative net change, however, sums to only a negative 0.2 percent change. Direct relief had a stronger effect on private earnings. The cumulative increase in earnings following a shock to direct relief was 6.2 percent. Assuming a monthly wage of 102 dollars, this would have meant extra payments summing to $\$ 6.32$ over the period.

WPA spending had a different relationship with the private labor market than the combination of direct and work relief in the First New Deal and the direct relief spending during the Second New Deal. At several points during the New Deal, there were positive shocks to a city's WPA budget when the federal relief administration approved a new works project. ${ }^{31}$ Although New Deal administrators tried to prevent WPA work relief from having a negative impact on private employment, the impulse response function in the chart in row 1 column 4 in Figure 4 shows that an increase in work relief spending at time zero was associated with a statistically significant decrease in private employment that peaked at -0.20 percent before slowly decaying back to zero.

The sum of all the deviations in WPA spending over the entire 36-month period associated with the initial shock in WPA spending is 90 percent. If we assume that all of this increase went to an increase in the number of work relief job months rather than higher work relief pay, it would have meant a 90 percent increase in WPA jobs relative to the mean number in the city. In Cleveland, which averaged about 39,100 WPA jobs per month in this period, the initial one-standard deviation shock would have led to an additional 35,200 relief job months over the 36-month period. ${ }^{32}$

Meanwhile, the cumulative effect of the WPA shock was to reduce the number of job months of private employment over the following 36 months by 4.9 percent. In Cleveland, where mean employment was around 480,000 workers in this period, this translates into a

\footnotetext{
${ }^{31}$ Howard (1941, notes on pp. 106-7) describes the WPA as having a hand-to-mouth existence because the funding was enacted piece-meal over time. In 1939, for example, the Emergency Relief Appropriation Act was not passed until 11:30 on June 30, a half-hour before the start of the new fiscal year. The WPA had already laid off workers in June because of the uncertainty. Some new WPA appropriations were enacted as supplementary measures in other parts of the year. Even though the bills were designed to fund the entire WPA, the timing of their impact might have varied from city to city based on the timing of project approvals related to the total WPA budget.

${ }^{32}$ Assumes 172 110, 106, and 97 hours a month per job for Cleveland, New York and Los Angeles which is their respective state's average..
} 
cumulative decrease in private job months of approximately 23,500 over the 36-month period. ${ }^{33}$ The comparison suggests that for every relief job month added over the period, private sector employment declined by approximately 0.66 job months. Using the same procedure and assumptions an additional work relief job month would have decreased private employment by 1.33 and 0.92 job months in Los Angeles and New York respectively. We should note, however, that even though the IRF in row 1 column 4 of Figure 4 shows some periods of statistically significant effects, the Granger-causality tests did not find that the WPA statistically significantly Granger-caused employment.

At the same time, the one standard deviation shock to WPA spending was also associated with a rise in private monthly earnings (see column 4 row 2 of Figure 9). At its peak the WPA shock raised private earnings over 0.2 percent from its mean. After adding up the deviations from the mean over the 36-month period, the cumulative effect is 5.7 percent. Assuming a monthly wage of 102 dollars this would mean a typical worker would have received a total of $\$ 5.84$ in extra pay spread over the period. Here again, there tests for Granger-causality did not find that the WPA statistically significantly Granger-caused monthly earnings.

The point estimates suggestion that a work relief shock would be followed by lower private employment and a slight increase in monthly earnings. That is consistent with a model of crowding out. It is important to note, however, that the impulse response functions are not providing a pure estimate of crowding out in the sense that a work relief job in time $t$ led to the elimination of a private job in time $t$. Instead of a pure crowding out effect, the IRFs show that the complex feedbacks between relief and the private labor market led to a negative relationship between work relief and private employment and a positive relationship between work relief and private earnings over an extended period of time.

\footnotetext{
${ }^{33}$ Cleveland had a population of 1.2 million. Assuming a labor force participation rate of $46.6 \%$ and an average unemployment rate of $15 \%$, the employed population would have been 480,000 .
} 
Figure 4

Impulse Responses to a one standard deviation positive shock at time zero--Specification 3
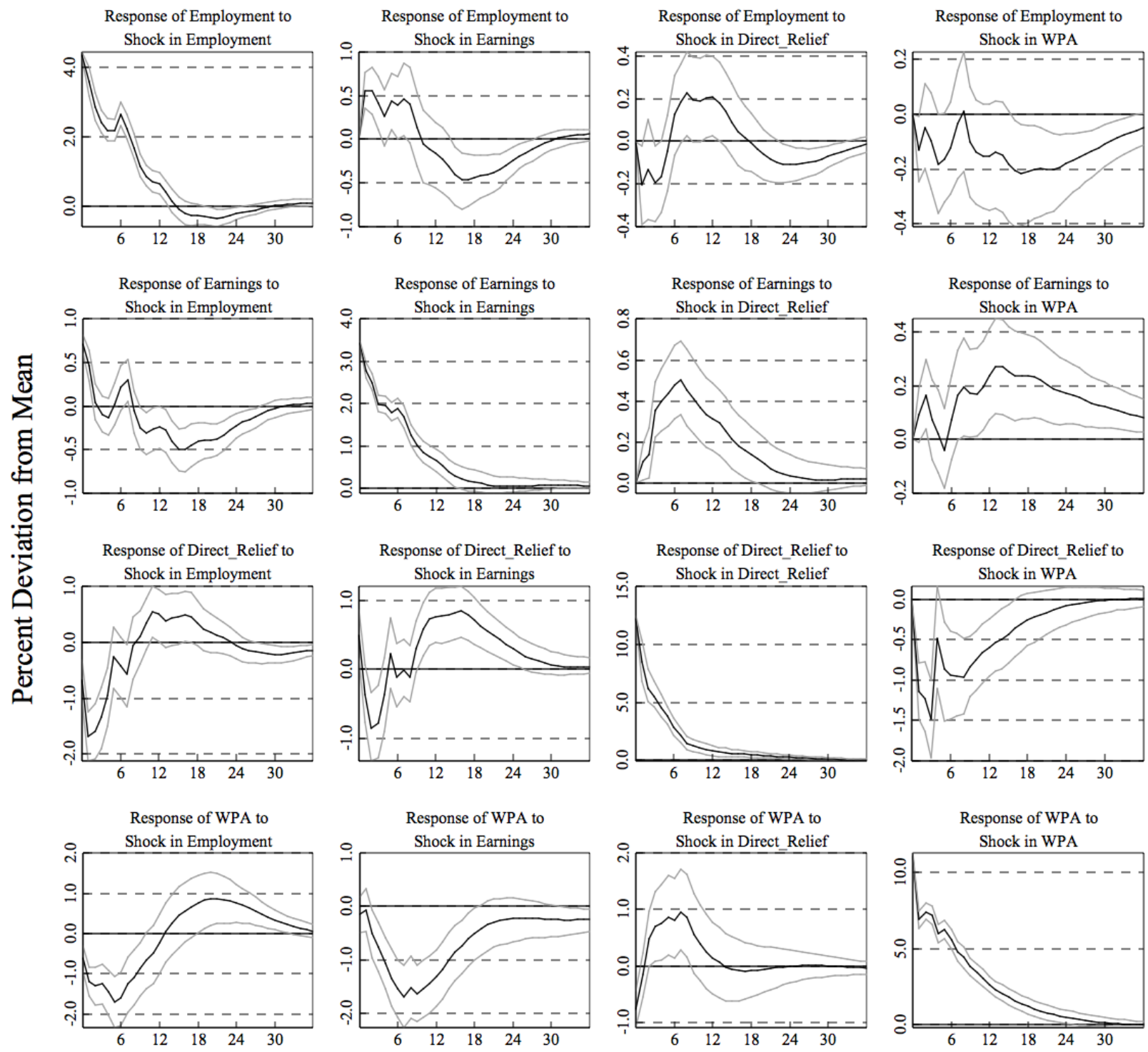

Months after Shock

Source: See Text

These relationships can help explain a common occurrence during the New Deal. Private employers complained that the WPA earnings were too high and that they were having trouble hiring workers at wages they had been paying before. Among the numerous reports, a June 1937 survey of State Administrators of the New Deal by the Office of Government Reports found that private industry expressed interest in hiring WPA workers in 35 states but a number of workers were reluctant to accept private work and some actually refused in 19 of the states (Petree, 15 
June 1937). The type of work refused ranged from domestic labor to farm labor to factory work to skilled labor (Howard 1943, 487-88). ${ }^{34}$

Worried about this issue, the WPA investigated their procedures and typically found that the local project managers were encouraging workers to accept private jobs when the jobs became available. In general, the WPA did not require workers to accept jobs paying less than the prevailing wage. In some cases, the workers were even allowed to supplement WPA earnings with private earnings. At various times, the WPA promised workers an opportunity to return to work relief if the private job fell through. The results of the WPA investigations often turned up relatively few cases where workers had turned down private work at prevailing wages, and those who had were immediately fired. When the WPA officials reported the findings of their investigations they sounded a triumphant note that they had proved the complaining employers wrong. H.O. Hunter of the WPA in a 1939 radio address stated: "Now we have found one single overwhelming fact in all of these cases - as soon as we ask for concrete details, with names and dates, the stories melt away into nothing but idle rumor."35

The impulse response functions suggest, however, that the complaining employers and the WPA officials both were right, but they were talking past each other. The employers were describing real patterns and experiences that they were witnessing in their cities. They might not have been able to pin down precise names and dates, but they were seeing some upward pressure on the wages they had to pay and, thus, their incentives to hire diminished. Meanwhile, WPA officials could document that they were following the procedures that they had designed to avoid harming private labor markets. WPA wages that were "too high" in the employers" view did not have to exceed wages on private jobs. It is very possible that the security of the WPA job made the relief job attractive enough that employers were discovering that they were having trouble hiring workers in a time of extraordinarily high unemployment rates. The complex feedback effects from a work relief shock over time led them to see these patterns.

\footnotetext{
${ }^{34}$ For other examples of complaints, see Coyle (1939), Brimhall (1937), Petree (8 November, 1934, 15 April 1935, 27 April 1936, 17 August 1936, 15 September 1936, 9 October 1936, 15 June 1937, 12 July 1937; 13 September 1937), Larned (January 1935, 18 April 1935, 29 July 1935, 12 August 1935, 19 August 1935), Wood (13 July 1937), and Works Progress Administration (1937).

${ }^{35}$ Quoted in Howard $(1940,489)$. For other discussions of the investigations, see Coyle (1939), Brimhall (1937), Howard, (1940, 488-492, WPA (1937).
} 


\section{Did Relief Respond to Economic Distress?}

In the extensive debate over the political economy of New Deal spending, part of the discussion has centered on the extent to which New Deal spending responded to problems in the economy. Typically, the cross-sectional studies that focused on the effect of the economy on relief used measures of economic activity from earlier periods to avoid simultaneity bias. The studies have shown that areas that had higher unemployment and/or experienced downturns tended to receive more federal money for relief. The monthly data and panel VAR offer the first opportunity to examine how the timing of relief funds responded to economic upturns and downturns within the same city.

The analysis of aggregate relief spending over the entire period summarized in Figure 2 shows that relief responded strongly to shocks to the private labor market. Following a onestandard deviation increase in employment of over five percent (column 1, row 3), relief fell more than two percent below the mean. It remained there from months 2 through 5 , and then the negative effect decayed towards zero. Cumulatively, relief fell 26 percent over the three years compared with the cumulative increase in job months of 39 percent. Relief spending also responded to positive shocks in private earnings in a negative fashion (in column 2 row 3 of Figure 2) for the most part with statistically significant effects in months 3 through 5 . In this case cumulated relief falls 11 percent compared with the cumulated increase in private earnings of 53 percent.

The charts in the third row of Figure 3 show that during the First New Deal general relief spending responded to improvements in the private labor market. General relief drops immediately following a positive shock to either employment or earnings. Six months after a shock to employment, however, general relief has returned to its mean. The cumulative effect of the positive shock to employment is a 12 percent decrease in general relief compared with a total increase in employment of 18 percent. Following the positive shock in earnings that results in a cumulative increase in of 11 percent, general relief spending falls a cumulative total of 3 percent.

During the Second New Deal, the IRFs for direct relief in row 3 of Figure 4 show that a positive shock to the private employment, which led to a cumulative increase in employment of 25 percent, would have been followed by decreases in direct relief spending. The shock to employment is followed by decreases in direct relief for six to eight months and then increases in direct relief for a period after that. The cumulative change in direct relief was to a drop of 5 
percent. Meanwhile the shock to monthly earnings that cumulated to a 26 percent increase in earnings was associated with a cumulative 6 percent increase in direct relief spending.

Figure 4 suggests that WPA officials responded initially to positive shocks to the labor market during the Second New Deal by reducing spending, although the feedbacks after about 12 months ultimately ended up leading to WPA spending as high as 1 percent above the mean in the second half of the second year (row 4 column 1). Meanwhile positive shocks to monthly earnings were followed by drops in WPA spending relative to the mean throughout the period (row 4 column 2 in Figure 4). The cumulative response of WPA spending to an employment shock was -2 percent and -24 percent for an earnings shock. Using Cleveland as an example again, the shock to private employment ultimately was associated with a cumulative increase of 121,000 private job months and a decrease of 800 relief job months over a three-year period. The cumulative effect of the increase in earnings in Cleveland would represent a loss of approximately 9,600 WPA job months.

\section{Elections and the Timing of Relief Spending}

Contemporary critics claimed that the Roosevelt administration had been trying to "buy" votes by timing increases in relief to coincide with impending elections. In both 1936 and 1938, the national WPA numbers showed all-time highs in WPA employment in October and November, followed by December declines. The WPA's defense of the timing was that they were striving to offset unemployment caused by seasonality, droughts, and unusual periods of unemployment around the country. WPA officials argued that comparisons of WPA employment across states did not show higher than normal WPA employment in states where elections were tight (Howard 1943, 586-594).

We can use the monthly data on relief and private labor markets to determine how much of the variation in spending that is not directly related to economic activity was timed to occur near election time. To the extent that the electorate's attitude can be expressed as "What have you done for me lately?" we expect that efforts to use spending to aid re-election chances would be timed to be higher in the final months of the campaign. To capture the timing, we begin by estimating Equation (3) for the period January 1936 through December 1939. Note that this is simply the relief equation from the VAR model in specification $3 .^{36}$

\footnotetext{
${ }^{36}$ The variables used to estimate Equation 3 have not been time demeaned.
} 
(3) $W P A_{i t}=\sum_{t=1}^{48} t e_{t}+\sum_{j=1}^{9} a_{j}^{W P A} W P A_{i t-j}+\sum_{j=1}^{9} a_{j}^{E m p} \operatorname{Emp}_{i t-j}+\sum_{j=1}^{9} a_{j}^{\text {Earn }} \operatorname{Earn}_{i t-j}+\sum_{j=1}^{9} a_{j}^{\text {Direct }} \operatorname{Direct}_{i t-j}+e_{i t}^{W P A}$

Figure 5 plots the WPA time effects from equation 3 as deviations from the mean on the same horizontal twelve-month scale. These are the WPA spending patterns associated with each time period after controlling for local employment and earnings and past spending behavior. They show two clear patterns. First, WPA spending during an election year, holding private market activity constant, was higher than during non-election years. Second, the spending in the months August through November, the period encompassing the final months of an election, was higher in federal election years than in non-election years. Both of these differences were statistically significant at the 5 percent level. The only time of year in which the non-election year spending was similar to federal election year spending was in December, the month after the election and again in March. As a result, the timing of WPA spending, even after controlling for local economic activity seems consistent with the view that it was timed to influence federal elections. 
Figure 5

WPA spending patterns by month of the year

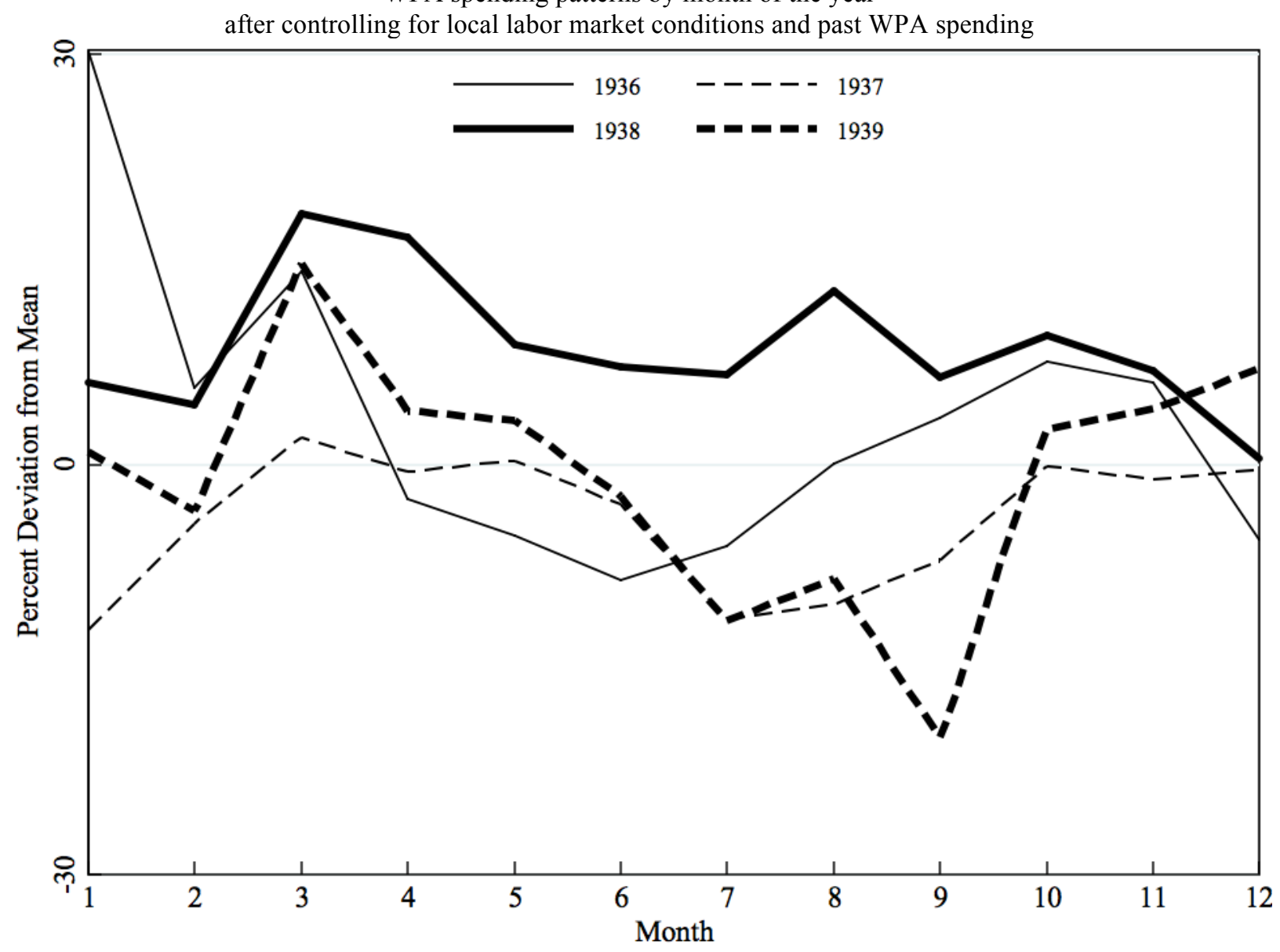

\section{Discussion}

Although more than six decades have passed since the end of the Great Depression, economists are only now beginning to develop a good understanding of the interactions of labor markets and relief programs during the 1930s. This paper takes advantage of monthly data for 44 cities to portray the dynamic reduced-form relationships between private labor market activity and relief spending during the 1930s. The analysis captures the relationships between relief and private labor markets at the local level after controlling for common nationwide shocks and for time-invariant differences in the level of relief and labor market activity in each city's local economy.

When we analyze all relief programs in aggregate across the whole New Deal, increases in relief spending are followed by relatively decreases in employment and increases in monthly earnings. However, the aggregation hides substantial differences in the relationships found 
during the period of the First New Deal (through June 1935) and the period of the Second New Deal (after December 1935).

Because we have controlled for the differences in nationwide shocks that occurred each month, we believe that the differences in the relationships between the first and second periods are related to the differences in the structural economic environment of the two periods. During the First New Deal, when the economic problems were at their worst, a rise in the combination of direct and work relief spending distributed by the FERA and state and local governments was followed by increases in employment and monthly earnings. The cumulative effects suggest that the FERA direct and work relief spending had a net stimulative effect on private labor markets. A rough estimate based on the cumulative responses suggests that an increase of eight work relief case months eventually gave rise to an additional private job month.

After two years of recovery and a series of reorganizations of New Deal programs, the impact of the programs changed substantially. After December 1935 the direct relief spending run by the state and local governments had a much weaker and slightly net negative relationship with private employment. Monthly earnings responded positively. Meanwhile, the relationships between WPA work relief and private employment were quite different from the patterns estimated between general relief spending and employment during the FERA era. A positive shock to WPA spending was followed by a proportional decline in private employment, such that the addition of one relief job month over the period yielded a reduction of 0.6 to 1.3 private job months. In addition, increases in work relief were associated with increases in private monthly earnings. The patterns found for the WPA help explain a wide range of complaints filed by employers against the WPA despite the WPA's administrative efforts to get workers to accept jobs. Given the possibility of measurement error in the employment variable the size of these effects should be viewed as a rough approximation. The true effects may be larger or smaller. The dynamics and direction of the relationships, we believe, are less likely to be affected by this measurement error. The implication is that a real change in the relationship between relief and the private labor market occurred during the 1930s.

At this stage we can only speculate about the reasons for the change in responses between the two periods. However, there are a number of differences between the periods that may have contributed. Although the positive response from the earlier period was estimated for combined work and direct relief, it seems reasonable that each had a positive relationship with 
employment before July 1935. Yet during the second New Deal, shocks to direct and work relief have either no effect or a negative effect on employment. The change for direct relief may stem from the elimination of federal funding of direct relief after 1936. After 1936 state and local governments were forced to fund direct relief with state and local tax dollars with the result that external funds were no longer injected into the community.

The changing response of employment to work relief cannot reflect different funding, because the WPA, like the FERA, was primarily funded by federal dollars. Instead, the difference in the effects might have been driven by structural changes in the economic environment between the First and Second New Deal.

During the earlier period unemployment rates including those on work relief ranged between 20.1 and 24.9 percent; the rates were 14.2 to 20.6 percent if those on work relief are not included. Real GDP still remained 11.4 percent below the 1929 peak in 1935 after reaching a trough of 27 percent below the peak in 1933. During the First New Deal, the National Recovery Administration had been established to allow industry to establish codes of "fair competition" that allowed them to raise prices and hourly wages. The reduced-form microeconomic effect of the NRA codes was to reduce employment, total hours worked, and industry output (Taylor 2008 Tables 3 and 4). In short, this is a period when the code policies were slowing the hiring of workers and there was a vast pool of available labor. Crowding out effects were much less likely in this environment.

After 1935, on the other hand, the WPA was operating in an environment where real GDP had recovered enough to exceed its 1929 level. Unemployment rates had fallen to 14 to 19 percent including work relief workers, and 9.1 to 12.5 without them. In short during the Second New Deal the economy was growing, private employers no longer were covered by the NRA codes and thus faced fewer constraints on their hiring, and the pool of unemployed labor was smaller, although still substantial.

Finally a worker's perception of work relief likely changed between the First and Second New Deals. During the earlier period work relief was a new and unfamiliar concept run by the same agency that handled direct relief. This new "welfare" program may then have been viewed less as a job and more as a handout. Additionally the newness of the program might have raised questions about its future. The creation of the WPA in 1935, after two full years of extensive work relief hiring, likely sent two strong signals. First work relief and direct relief had been 
officially separated, potentially reducing the "welfare" connotations of work relief programs. Second, the creation of a new agency to handle work relief likely signaled a level of permanence to the program. The program was still called an emergency program but many Democrats were lobbying to make the WPA more permanent. Together these would have worked to make a WPA job more like a low-risk substitute for a private sector job in the mind of a worker, a prospect borne out by the significant length of time that many people stayed on work relief under the WPA. Relative to the situation in the First New Deal, one might expect that the negative labor supply-side consequences were more likely to overwhelm any stimulative effects of the work relief payments during the Second New Deal.

Finally the dynamics we document also contribute to the large literature on the extent to which the distribution of New Deal funds reflected Roosevelt's declared goal of promoting relief and recovery. While nearly all of the prior work has focused on cross-sectional analysis, the results of the panel analysis show that relief spending increased after declines in private employment and earnings in a way that helped promote recovery. On the other hand, the monthly variation in relief spending also yields evidence consistent with presidential politicking. Once everything is controlled for, it turns out that WPA work relief spending was higher in federal election years than in off years, and the election year spending showed increases in the late summer and early fall months leading into the November election. 


\section{Appendix A.}

\section{Variable Construction}

This appendix describes the sources and methods employed in constructing the six variables summarized in Table 1; an employment index, an earnings index, per capita total relief spending, per capita WPA spending, per capita general relief spending, and per capita CWA spending.

\section{Employment and Earnings Indices}

The raw Payroll and Employment data are measured on a city/month basis using a linkedrelative procedure. The state departments of labor in conjunction with the Bureau of Labor Statistics conducted surveys of establishments each month with some firms added and some firms subtracted. Information on the amount of the payroll and the number employed was reported as the percentage change from the previous month for firms that appear in both the survey in the previous month and the survey in the current month. The original sources are Arnold and Yocum, 1949; Commonwealth of Massachusetts, various years; Commonwealth of Pennsylvania, various; State of Illinois Labor Department, various; State of New York Industrial Commissioner, various, State of Michigan Commissioner of Labor, various, U.S. Bureau of Labor Statistics, various issues; Wisconsin Industrial Commission, various issues. The raw employment data vary by city. Most of the states report a total for the combination of manufacturing and non-manufacturing employment; the New Jersey cities, all Massachusetts cities except Boston, all Ohio cities except Cleveland report only manufacturing. Some states record raw numbers while others record indices. In order to make this data comparable, all raw employment and payroll data are converted into chain indices with June 1935 as the base year using the following formulas (c indexes the city and the month):

Employment Index $_{\mathrm{ct}}=$ Employment $_{\text {Measure }} \mathrm{ct}$ Employment Measure EJune $_{1935}$

Payroll Index $_{\mathrm{ct}}=$ Payroll Measure $_{\mathrm{ct}} /$ Payroll Measure $_{\mathrm{cJune}} 1935$

The earnings index is then created using the following formula:

$$
\text { Earnings Index } \mathrm{ct}_{\mathrm{ct}}=\text { Payroll Index }_{\mathrm{ct}} / \text { Employment Index }_{\mathrm{ct}}
$$




\section{Real Per Capita Relief Spending}

We start with three raw measures of relief:

1. Nominal CWA Spending at the City level over the total life of CWA.

2. Nominal General Relief Spending at the City/Month level from 1933-1939

a. Missing $1 / 33-6 / 33 \& 4 / 37-11 / 37$

3. Nominal WPA Spending at the City/Month level 1933-1939

These data come from a number of sources. The WPA measures come from the Records of the Work Progress Administration found on microfiche at the National Archives in Washington ([National Archives, Record Group 69, Microfilm Number Reel 5033). The information on FERA, the CWA, and state and local general relief spending comes from the Federal Emergency Relief Administration Annual Reports (various issues). These data are augmented with material from the Final Statistical Report of the Federal Emergency Relief Agency (FERA, 1940) and the Federal Works Agency Works Progress Administration's Report on Progress of the WPA Program (Federal Works Agency, 1940). In order to construct the variables used in the paper the following steps are performed.

\section{Convert total CWA city level spending to a city/month measure}

We create monthly variation in city level CWA spending by using monthly variation in CWA spending in the state where the city was located using the following formula:

$$
\mathrm{CWA}_{\mathrm{ct}}=\mathrm{CWA}_{\mathrm{c}} *\left(\mathrm{CWA}_{\mathrm{st}} / \mathrm{CWA}_{\mathrm{s}}\right)
$$

where $\mathrm{CWA}_{\mathrm{ct}}$ is the estimate of CWA spending in city $\mathrm{c}$ in month $\mathrm{t}, \mathrm{CWA}_{\mathrm{c}}$ is the reported total CWA spending in city $\mathrm{c}$ for the entire life of the $\mathrm{CWA}, \mathrm{CWA}_{\mathrm{st}}$ is the CWA spending for the state in which the city is located in month $\mathrm{t}$ and $\mathrm{CWA}_{\mathrm{s}}$ is CWA state spending for the entire life of the CWA.

\section{Filling in Missing General Relief Data}

General Relief Spending is missing for the months of January through June of 1933 and April through November 1937. We use variation in state General Relief during these months to 
predict the city level numbers. The following section explains in detail the procedures used and how we test the validity of those methods To develop estimates for the missing general relief data for January 1933 through May 1933, we started by estimating the following regression for the period June 1933 through December 1934.

$$
\ln \left(\mathrm{GR}_{\mathrm{ct}}\right)=\alpha \ln \left(\mathrm{GR}_{\mathrm{st}}\right)+\beta \text { City }+\gamma \text { Year, }
$$

where $\ln$ is the natural $\log , \mathrm{GR}_{\mathrm{ct}}$ is General Relief in city $\mathrm{c}$ in month-year $\mathrm{t}$ and $\mathrm{GR}_{\mathrm{st}}$ is General Relief in state s where the city was located in month year $t$, City is a vector of city effects with a vector of coefficients $\beta$ and year is a vector of year dummies with a vector of coefficients $\gamma$. We then predicted values for each city using the information on the state values during the period January 1933 through May 1933.

$$
\text { Predicted } \ln \left(\mathrm{GR}_{\mathrm{ct}}\right)=\alpha \text {-hat } \ln \left(\mathrm{GR}_{\mathrm{st}}\right)+\beta \text {-hat City }+\gamma \text {-hat Year, }
$$

where the hats refer to the estimated coefficients. The predicted General Relief is therefore,

$$
\text { Predicted } \mathrm{GR}_{\mathrm{ct}}=\operatorname{antilog}\left(\operatorname{Predicted} \ln \left(\mathrm{GR}_{\mathrm{ct}}\right)\right) \text {. }
$$

We followed the same procedure to replace the missing General Relief information for April 1937 through November 1937 with different time periods. We estimated the regression model for the months January 1936 through March 1936 and December 1936 through December 1938. We then used the regression coefficients and the state information for the months April 1937 through November 1937 to predict the city values for April 1937 through November 1937. In summary we use an OLS regression to estimate the relationship between state level monthly spending and city level monthly spending around the times of the missing data. We then use the coefficients from this regression and the available state data to predict the city level data. We can then compare the in sample predictions with the actual values to access how well our method may perform in picking up between and within city variation in spending.

To check the quality of within city predictions we ran correlations by city for the actual values on the predicted values for the cities in the period June 1933 through December 1934 and 
again for the period January 1936 through March 1936 and December 1936 through December 1938 when we had both city and state information. The correlations of the predicted and actual values for each city were above 0.95 in 43.2 percent of the cities, between 0.9 and 0.95 in 45.5 percent, between 0.8 and 0.9 in 9.1 percent, between 0.7 and 0.8 in 2.3 percent. We also ran correlations by month to check between city correlations. These were all over 0.95 .

\section{Convert to per capita real values}

Price adjustments are made using a city level Consumer Price Index for all items from the United States Bureau of Labor Statistics. CPI observations are bi-annual between 1932 and 1934 and quarterly between 1935 and 1940. Monthly observations are based on a straight-line interpolation. A select number of cities lacked price data in which case the closest neighbor's data was used. Because the base year differed across cities the price level index was re-indexed to June 1935 using the following formula:

New Price Level Index $\mathrm{ct}_{\mathrm{ct}}=$ Old Price Level $\mathrm{c}_{\mathrm{ct}} /$ Price Level $_{\mathrm{cJune}} 1935$

All variables except employment are deflated using the following formula:

$$
\text { New Variable }{ }_{\mathrm{ct}}=\text { Old Variable } \mathrm{ct} / \text { Price Level }_{\mathrm{ct}}
$$

Finally WPA spending, CWA spending and General Relief spending are converted into per capita measures using the following formula:

$$
\text { Per cap Variable } \mathrm{ct}_{\mathrm{ct}}=\text { Variable }_{\mathrm{ct}} / \text { Population }_{\mathrm{ct}}
$$

Population measures come from the U.S. Bureau of Census' 1930 and 1940 Census. Monthly population figures are based on a straight-line interpolation between the two dates.

\section{Sample}

The data above are combined to create our unbalanced panel of relief and labor market measures from 44 urban cities between 1933 and 1939; specifically: San Francisco, Los Angeles, 
Canton-OH, Cleveland, Cincinnati, Dayton, Columbus, Toledo, Youngstown, Akron, Syracuse, Rochester, Albany, Buffalo, New York City, Utica, Detroit, Baltimore, Lynn-MA, Lowell, Boston, Springfield-MA, Brockton, Cambridge, Fall River, Lawrence, Worchester-MA, Minneapolis, St. Paul, Duluth, Chicago, Springfield-IL, Kansas City-KS, Topeka, Wichita, Milwaukee, Kenosha, Racine, Philadelphia, Pittsburg, St. Louis, Jersey City, Newark, Trenton. These specific cities are used because relief, employment, and demographic variables were available. The sample is unbalanced because employment data is unavailable for four cities prior to June of 1934 and unavailable after 1938 for 6 cities. 


\section{Appendix B.}

VAR Coefficient Results for Specifications 1, 2, and 3

Table B.1

Panel VAR Coefficient Results-Specification 1

\begin{tabular}{|c|c|c|c|c|c|c|c|}
\hline \multirow[b]{3}{*}{ Independent Variable } & \multirow[b]{3}{*}{ Lag } & \multicolumn{6}{|c|}{ Dependent Variable } \\
\hline & & \multicolumn{2}{|c|}{ Employment } & \multicolumn{2}{|c|}{ Earnings } & \multicolumn{2}{|c|}{ Relief } \\
\hline & & Beta & t-statistic & Beta & t-statistic & Beta & t-statistic \\
\hline Employment & 1 & 0.81 & 13.05 & 0.04 & 1.22 & -0.26 & -5.08 \\
\hline Earnings & 1 & 0.20 & 4.40 & 0.82 & 14.23 & -0.14 & -2.36 \\
\hline Relief & 1 & 0.00 & -0.54 & 0.00 & 0.62 & 0.86 & 20.26 \\
\hline Employment & 2 & 0.00 & -0.06 & -0.06 & -2.26 & 0.12 & 1.89 \\
\hline Earnings & 2 & -0.14 & -2.72 & 0.06 & 1.12 & 0.03 & 0.36 \\
\hline Relief & 2 & 0.01 & 0.83 & 0.00 & -0.35 & -0.06 & -1.24 \\
\hline Employment & 3 & 0.06 & 1.90 & -0.01 & -0.33 & 0.06 & 0.81 \\
\hline Earnings & 3 & 0.00 & -0.05 & -0.02 & -0.72 & 0.08 & 1.06 \\
\hline Relief & 3 & -0.02 & -2.46 & -0.01 & -0.70 & -0.04 & -0.92 \\
\hline Employment & 4 & -0.01 & -0.55 & 0.00 & 0.09 & -0.14 & -1.69 \\
\hline Earnings & 4 & -0.05 & -1.70 & 0.04 & 1.41 & -0.07 & -1.04 \\
\hline Relief & 4 & 0.01 & 0.52 & 0.02 & 1.80 & -0.03 & -1.07 \\
\hline Employment & 5 & 0.00 & -0.13 & 0.01 & 0.23 & 0.09 & 1.17 \\
\hline Earnings & 5 & 0.05 & 1.51 & 0.01 & 0.31 & 0.11 & 1.61 \\
\hline Relief & 5 & 0.03 & 2.19 & -0.01 & -1.06 & 0.05 & 1.73 \\
\hline Employment & 6 & 0.08 & 2.63 & 0.02 & 0.56 & 0.02 & 0.36 \\
\hline Earnings & 6 & -0.02 & -0.51 & 0.08 & 2.83 & -0.01 & -0.21 \\
\hline Relief & 6 & -0.02 & -2.61 & 0.01 & 1.41 & 0.04 & 1.99 \\
\hline Employment & 7 & -0.04 & -1.52 & 0.03 & 1.18 & 0.12 & 1.93 \\
\hline Earnings & 7 & -0.01 & -0.43 & -0.04 & -1.41 & 0.06 & 0.71 \\
\hline Relief & 7 & 0.01 & 0.75 & 0.00 & -0.03 & -0.03 & -1.79 \\
\hline Employment & 8 & -0.02 & -0.86 & -0.04 & -1.44 & -0.13 & -1.90 \\
\hline Earnings & 8 & -0.01 & -0.34 & -0.05 & -1.81 & -0.12 & -1.35 \\
\hline Relief & 8 & -0.01 & -1.33 & -0.01 & -0.95 & 0.03 & 1.65 \\
\hline Employment & 9 & 0.00 & 0.14 & 0.00 & 0.09 & 0.01 & 0.18 \\
\hline Earnings & 9 & -0.01 & -0.24 & 0.02 & 1.03 & 0.02 & 0.34 \\
\hline Relief & 9 & 0.01 & 1.30 & 0.00 & 0.34 & 0.02 & 1.29 \\
\hline $\mathrm{N}$ & & & & & 3139 & & \\
\hline
\end{tabular}


Table B. 2

Panel VAR Coefficient Results-Specification 2

\begin{tabular}{|c|c|c|c|c|c|c|c|c|c|}
\hline \multirow[b]{3}{*}{ Independent Variable } & \multirow[b]{3}{*}{ Lag } & \multicolumn{8}{|c|}{ Dependent Variable } \\
\hline & & \multicolumn{2}{|c|}{ Employment } & \multicolumn{2}{|c|}{ Earnings } & \multicolumn{2}{|c|}{ General } & \multicolumn{2}{|c|}{ CWA } \\
\hline & & Beta & t-statistic & Beta & t-statistic & Beta & t-statistic & Beta & t-statistic \\
\hline Employment & 1 & 0.71 & 10.09 & 0.15 & 3.63 & -0.31 & -2.65 & -0.11 & -0.51 \\
\hline Earnings & 1 & 0.25 & 4.08 & 0.54 & 6.80 & -0.19 & -2.16 & -0.44 & -1.64 \\
\hline General & 1 & -0.02 & -1.34 & 0.00 & 0.26 & 0.44 & 9.78 & 0.16 & 1.70 \\
\hline CWA & 1 & 0.00 & 0.29 & 0.00 & -0.43 & -0.03 & -1.82 & 0.31 & 5.05 \\
\hline Employment & 2 & 0.00 & -0.02 & -0.04 & -0.94 & -0.14 & -1.14 & 0.08 & 0.33 \\
\hline Earnings & 2 & -0.14 & -2.44 & 0.07 & 1.19 & 0.07 & 0.59 & 0.02 & 0.09 \\
\hline General & 2 & 0.01 & 0.49 & 0.00 & -0.01 & 0.16 & 3.63 & -0.08 & -0.94 \\
\hline CWA & 2 & 0.00 & 0.05 & 0.00 & -0.80 & -0.01 & -1.17 & -0.37 & -4.56 \\
\hline Employment & 3 & 0.08 & 1.48 & -0.04 & -0.71 & 0.25 & 2.00 & 0.41 & 1.21 \\
\hline Earnings & 3 & 0.00 & 0.03 & -0.01 & -0.16 & 0.00 & -0.02 & 0.19 & 0.74 \\
\hline General & 3 & -0.01 & -0.69 & 0.00 & -0.05 & 0.10 & 2.39 & -0.05 & -0.63 \\
\hline CWA & 3 & -0.01 & -3.62 & 0.01 & 1.10 & -0.02 & -1.67 & -0.11 & -2.05 \\
\hline Employment & 4 & -0.09 & -2.09 & -0.04 & -0.95 & 0.02 & 0.18 & -0.52 & -1.64 \\
\hline Earnings & 4 & -0.07 & -1.61 & -0.05 & -1.10 & -0.16 & -1.24 & -0.32 & -1.11 \\
\hline General & 4 & 0.00 & 0.11 & 0.01 & 0.78 & -0.01 & -0.28 & 0.00 & 0.04 \\
\hline CWA & 4 & 0.00 & -0.72 & 0.00 & 0.84 & -0.04 & -2.90 & 0.06 & 1.37 \\
\hline Employment & 5 & -0.07 & -1.73 & -0.05 & -0.89 & 0.01 & 0.10 & -0.20 & -0.80 \\
\hline Earnings & 5 & 0.00 & -0.05 & 0.00 & -0.03 & 0.01 & 0.09 & 0.02 & 0.09 \\
\hline General & 5 & 0.02 & 1.15 & -0.02 & -1.03 & -0.07 & -1.70 & -0.04 & -0.58 \\
\hline CWA & 5 & 0.01 & 1.06 & 0.01 & 1.31 & -0.06 & -4.51 & -0.10 & -2.91 \\
\hline Employment & 6 & 0.06 & 1.32 & 0.03 & 0.55 & -0.10 & -1.03 & 0.03 & 0.13 \\
\hline Earnings & 6 & -0.01 & -0.26 & 0.07 & 1.48 & 0.13 & 1.22 & 0.34 & 1.29 \\
\hline General & 6 & -0.01 & -0.42 & 0.00 & -0.02 & -0.01 & -0.14 & 0.00 & -0.03 \\
\hline CWA & 6 & -0.01 & -1.67 & 0.00 & 0.58 & -0.03 & -2.46 & 0.08 & 2.70 \\
\hline Employment & 7 & 0.05 & 1.08 & 0.05 & 1.28 & 0.16 & 1.26 & -0.02 & -0.09 \\
\hline Earnings & 7 & -0.03 & -0.60 & -0.10 & -2.10 & -0.02 & -0.21 & 0.34 & 1.56 \\
\hline General & 7 & 0.00 & -0.15 & 0.01 & 0.68 & 0.03 & 0.73 & -0.10 & -1.78 \\
\hline CWA & 7 & 0.00 & -0.27 & 0.00 & -0.49 & -0.01 & -0.71 & 0.04 & 1.32 \\
\hline Employment & 8 & 0.01 & 0.14 & 0.05 & 1.07 & -0.12 & -0.86 & -0.20 & -1.00 \\
\hline Earnings & 8 & 0.02 & 0.50 & 0.03 & 0.57 & 0.10 & 0.79 & -0.03 & -0.09 \\
\hline General & 8 & 0.00 & 0.14 & 0.01 & 0.57 & -0.04 & -0.99 & -0.13 & -2.22 \\
\hline CWA & 8 & 0.00 & 0.19 & 0.00 & -1.12 & -0.03 & -2.46 & 0.01 & 0.60 \\
\hline Employment & 9 & -0.05 & -1.35 & -0.02 & -0.61 & -0.08 & -0.65 & -0.08 & -0.40 \\
\hline Earnings & 9 & -0.02 & -0.45 & -0.02 & -0.63 & -0.19 & -1.70 & -0.40 & -1.57 \\
\hline General & 9 & 0.00 & 0.14 & 0.00 & 0.29 & -0.07 & -1.45 & 0.00 & 0.06 \\
\hline CWA & 9 & 0.01 & 1.25 & 0.00 & -1.19 & 0.01 & 0.75 & 0.08 & 3.84 \\
\hline $\mathrm{N}$ & & & & & & & & & \\
\hline
\end{tabular}


Table B. 3

Panel VAR Coefficient Results-Specification 3

\begin{tabular}{|c|c|c|c|c|c|c|c|c|c|}
\hline \multirow[b]{3}{*}{ Independent Variable } & \multirow[b]{3}{*}{ Lag } & \multicolumn{8}{|c|}{ Dependent Variable } \\
\hline & & \multicolumn{2}{|c|}{ Employment } & \multicolumn{2}{|c|}{ Earnings } & \multicolumn{2}{|c|}{ Direct } & \multicolumn{2}{|c|}{ WPA } \\
\hline & & Beta & t-statistic & Beta & t-statistic & Beta & t-statistic & Beta & t-statistic \\
\hline Employment & 1 & 0.80 & 10.45 & -0.02 & -0.87 & -0.26 & -3.67 & -0.18 & -3.31 \\
\hline Earnings & 1 & 0.16 & 3.51 & 0.81 & 19.99 & -0.21 & -2.75 & 0.00 & 0.06 \\
\hline Direct & 1 & -0.02 & -1.42 & 0.01 & 1.68 & 0.69 & 6.11 & 0.03 & 1.21 \\
\hline WPA & 1 & -0.01 & -1.38 & 0.01 & 1.23 & -0.10 & -4.20 & 0.62 & 16.33 \\
\hline Employment & 2 & -0.01 & -0.13 & -0.06 & -1.97 & 0.11 & 1.44 & 0.09 & 1.38 \\
\hline Earnings & 2 & -0.10 & -1.42 & 0.08 & 1.61 & 0.04 & 0.34 & -0.10 & -0.95 \\
\hline Direct & 2 & 0.01 & 0.84 & 0.00 & -0.29 & 0.02 & 0.23 & 0.04 & 1.95 \\
\hline WPA & 2 & 0.01 & 0.84 & 0.00 & 0.37 & 0.02 & 0.94 & 0.28 & 6.91 \\
\hline Employment & 3 & 0.05 & 1.40 & 0.04 & 1.12 & 0.01 & 0.11 & 0.06 & 0.89 \\
\hline Earnings & 3 & -0.05 & -0.84 & -0.06 & -1.51 & 0.07 & 0.69 & -0.01 & -0.09 \\
\hline Direct & 3 & -0.01 & -0.56 & 0.01 & 2.27 & 0.09 & 2.43 & 0.00 & -0.19 \\
\hline WPA & 3 & -0.01 & -0.52 & -0.01 & -1.70 & 0.00 & 0.11 & 0.06 & 1.61 \\
\hline Employment & 4 & 0.03 & 0.81 & 0.00 & 0.06 & 0.06 & 0.76 & -0.05 & -0.72 \\
\hline Earnings & 4 & -0.01 & -0.27 & 0.10 & 2.97 & 0.10 & 1.00 & -0.04 & -0.44 \\
\hline Direct & 4 & 0.00 & 0.41 & 0.00 & -0.98 & 0.00 & 0.06 & -0.02 & -0.90 \\
\hline WPA & 4 & 0.00 & -0.46 & 0.00 & -0.11 & 0.11 & 2.54 & -0.08 & -2.11 \\
\hline Employment & 5 & 0.04 & 1.10 & 0.05 & 1.48 & 0.10 & 1.33 & -0.04 & -0.58 \\
\hline Earnings & 5 & 0.06 & 1.60 & -0.02 & -0.53 & 0.10 & 0.92 & -0.02 & -0.23 \\
\hline Direct & 5 & 0.01 & 1.42 & 0.00 & 0.03 & 0.00 & 0.18 & 0.01 & 0.29 \\
\hline WPA & 5 & 0.01 & 0.67 & 0.00 & -0.24 & -0.07 & -1.52 & 0.06 & 1.44 \\
\hline Employment & 6 & 0.13 & 2.87 & 0.02 & 0.54 & -0.08 & -0.82 & 0.05 & 0.73 \\
\hline Earnings & 6 & -0.05 & -1.05 & 0.05 & 1.28 & -0.18 & -1.60 & 0.02 & 0.16 \\
\hline Direct & 6 & 0.01 & 1.99 & 0.00 & 0.86 & -0.03 & -1.56 & -0.01 & -0.53 \\
\hline WPA & 6 & 0.01 & 0.58 & 0.01 & 1.69 & -0.01 & -0.24 & -0.02 & -0.49 \\
\hline Employment & 7 & -0.14 & -3.30 & 0.01 & 0.26 & 0.01 & 0.09 & 0.10 & 1.41 \\
\hline Earnings & 7 & 0.00 & 0.06 & -0.05 & -1.22 & 0.08 & 0.86 & -0.01 & -0.13 \\
\hline Direct & 7 & 0.00 & -0.07 & 0.00 & 0.08 & 0.00 & -0.02 & 0.01 & 0.88 \\
\hline WPA & 7 & 0.01 & 0.71 & 0.00 & 0.51 & -0.01 & -0.21 & -0.05 & -1.24 \\
\hline Employment & 8 & -0.05 & -1.35 & -0.07 & -2.12 & 0.11 & 1.40 & -0.04 & -0.49 \\
\hline Earnings & 8 & 0.01 & 0.18 & -0.10 & -2.39 & -0.05 & -0.48 & 0.09 & 0.80 \\
\hline Direct & 8 & 0.00 & -0.62 & 0.00 & -0.96 & -0.01 & -0.56 & 0.00 & -0.22 \\
\hline WPA & 8 & 0.00 & -0.30 & 0.00 & -0.11 & 0.01 & 0.40 & 0.01 & 0.18 \\
\hline Employment & 9 & -0.02 & -0.84 & -0.02 & -0.91 & -0.08 & -1.34 & 0.01 & 0.13 \\
\hline Earnings & 9 & -0.04 & -1.41 & 0.05 & 1.83 & 0.08 & 1.10 & -0.04 & -0.54 \\
\hline Direct & 9 & -0.01 & -1.24 & 0.00 & -0.71 & 0.02 & 1.60 & -0.02 & -1.79 \\
\hline WPA & 9 & -0.01 & -1.39 & 0.00 & -0.53 & 0.00 & 0.21 & 0.00 & 0.09 \\
\hline $\mathrm{N}$ & & & & & & & & & \\
\hline
\end{tabular}




\section{Appendix C.}

Specification Tests \& Examination of Robustness

To examine robustness, we have also estimated four additional specifications in addition to the three reported in the text. These are listed in Appendix Table C.1. In specification 4 we estimate separate effects for the General Relief, CWA, and WPA for the entire time period. Because our measure of CWA spending uses state spending patterns to interpolate the monthly timing of city spending, we worry about measurement error; therefore, in specification 5 we reestimate the aggregate relief spending variable after eliminating the CWA, in specification 6 we re-estimate specification 4 for the entire period without the CWA, and in specification 7 we reestimate specification 2 without the CWA.

Appendix Table C.3. reports the number of statistically significant cross-correlations for lags of up to 19 periods under the 7 specifications that we estimate. All include 9 lags of the endogenous variables. In all cases fewer than 7 percent of the cross-correlations were statistically different from zero.

Appendix Table C. 4 compares the results of Granger causality tests for all specification tests. The Granger causality test results in WPA in specifications 4 are generally the same as in specification 3 despite the longer time period covered in specification 4. The General Relief test results in specification 4 differ in several cases from those of specification 2 for the First New Deal, likely because of the change in the nature of General Relief after June 1935.

Specifications 5, 6 and 7 are designed to see how the General Relief and WPA results change when we remove the CWA from the analysis. Comparisons of the results in specifications 1 and 5, 4 and 6 , and 2 and 7, respectively, suggest that the elimination of the CWA from the analysis changes few of the results of the Granger-Causality tests. 
Table C.1

Specifications in Text and for Robustness Testing

\begin{tabular}{cccccccc}
\hline $\begin{array}{c}\text { Measures of Relief } \\
\text { Included }\end{array}$ & 1 & 2 & 3 & 4 & 5 & 6 & 7 \\
\hline $\begin{array}{c}\text { Total Relief } \\
\left(\begin{array}{c}\text { Gen. WPA + CWA }) \\
\text { Total Relief } \\
(\text { Gen. }+ \text { WPA }) \\
\text { General }\end{array}\right.\end{array}$ & $\mathrm{X}$ & & & & & & \\
WPA & $\mathrm{X}$ & $\mathrm{X}$ & $\mathrm{X}$ & & $\mathrm{X}$ & $\mathrm{X}$ \\
CWA & & $\mathrm{X}$ & $\mathrm{X}$ & $\mathrm{X}$ & & $\mathrm{X}$ & \\
Time Period & $1933-40$ & $1933-$-June 35 & $1936-40$ & $1933-40$ & $1933-40$ & $1933-40$ & 1933-June 35 \\
\hline
\end{tabular}

Table C.2

Lag Length Specification Criteria

\begin{tabular}{ccc}
\hline Lags & AIC & BIC \\
\hline 1 & 20.218 & 20.236 \\
2 & 20.176 & $\mathbf{2 0 . 2 1 0}$ \\
3 & 20.173 & 20.225 \\
4 & 20.165 & 20.235 \\
5 & 20.159 & 20.246 \\
6 & 20.154 & 20.259 \\
7 & 20.151 & 20.272 \\
8 & $\mathbf{2 0 . 1 4 8}$ & 20.287 \\
9 & 20.152 & 20.308 \\
\hline
\end{tabular}

Table C.3

Residual Cross Correlations

\begin{tabular}{cccccccc}
\hline & \multicolumn{7}{c}{ VAR Specification } \\
& 1 & 2 & 3 & 4 & 5 & 6 & 7 \\
\hline Significant Correlations at 5\% & 9 & 16 & 11 & 32 & 9 & 14 & 2 \\
Possible Bad Pairs & 171 & 304 & 304 & 475 & 171 & 304 & 171 \\
Percent & $5.26 \%$ & $5.26 \%$ & $3.62 \%$ & $6.74 \%$ & $5.26 \%$ & $4.61 \%$ & $1.17 \%$ \\
\hline
\end{tabular}


Table C.4

Granger-Causality Tests for All Specifications

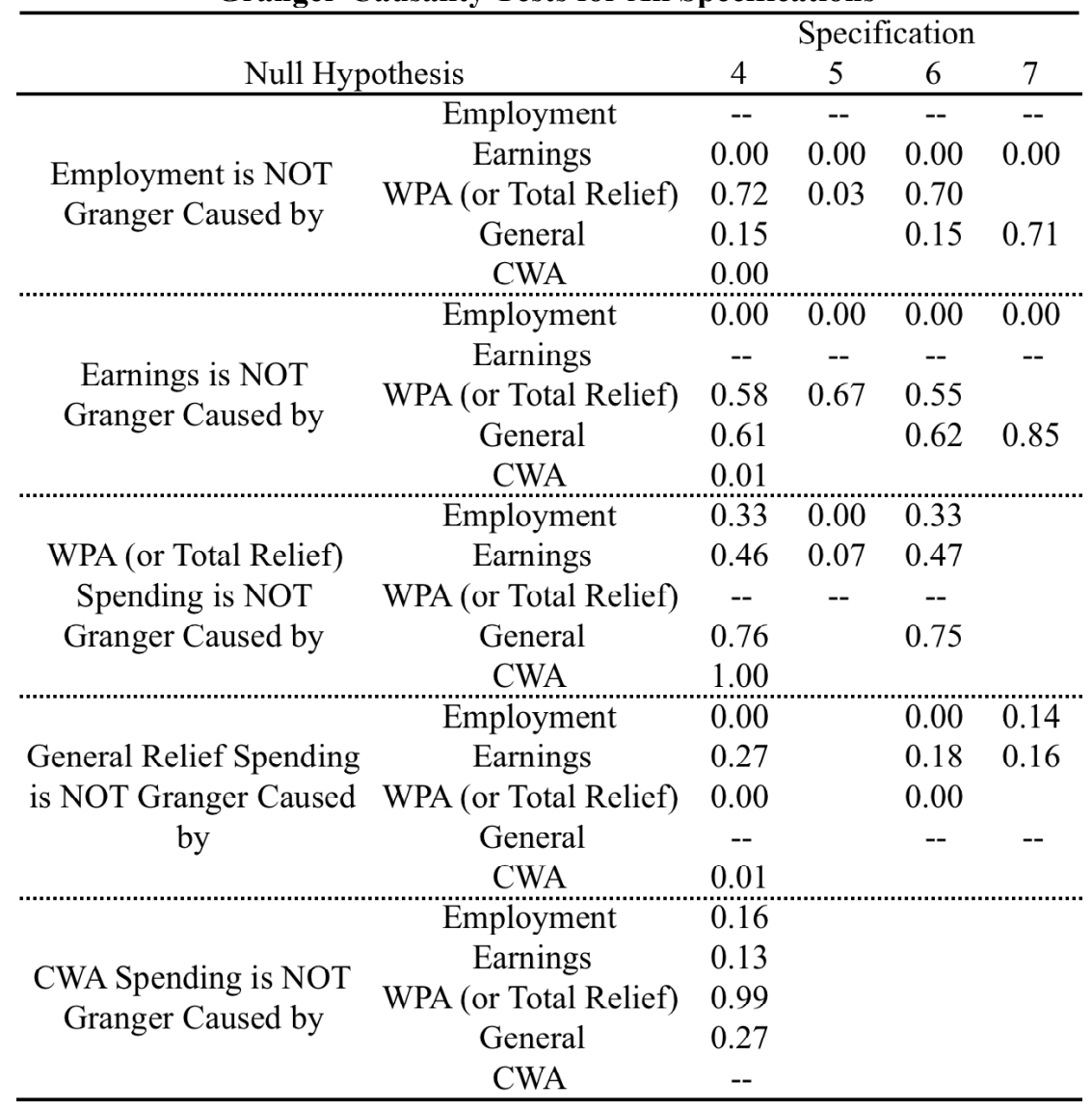


Table C.5

Panel VAR Coefficient Results-Specification 4

\begin{tabular}{|c|c|c|c|c|c|c|c|c|c|c|c|}
\hline \multirow[b]{3}{*}{ Independent Variable } & \multirow[b]{3}{*}{ Lag } & \multicolumn{10}{|c|}{ Dependent Variable } \\
\hline & & \multicolumn{2}{|c|}{ Employment } & \multicolumn{2}{|c|}{ Earnings } & \multicolumn{2}{|c|}{ General } & \multicolumn{2}{|c|}{ WPA } & \multicolumn{2}{|c|}{ CWA } \\
\hline & & Beta & t-statistic & Beta & t-statistic & Beta & t-statistic & Beta & t-statistic & Beta & t-statistic \\
\hline Employment & 1 & 0.80 & 13.15 & 0.04 & 1.27 & -0.27 & -3.53 & -0.15 & -3.25 & -0.10 & -0.47 \\
\hline Earnings & 1 & 0.20 & 4.41 & 0.81 & 14.12 & -0.20 & -2.98 & 0.00 & -0.03 & -0.38 & -1.64 \\
\hline General & 1 & -0.01 & -1.66 & 0.00 & 0.61 & 0.57 & 13.24 & 0.00 & -0.30 & 0.20 & 1.98 \\
\hline WPA & 1 & -0.01 & -1.41 & 0.00 & 0.43 & -0.10 & -5.89 & 0.72 & 19.12 & 0.00 & 0.05 \\
\hline CWA & 1 & 0.00 & 1.10 & 0.00 & -0.58 & -0.01 & -1.21 & 0.00 & -1.29 & 0.40 & 4.99 \\
\hline Employment & 2 & 0.00 & 0.01 & -0.06 & -2.31 & -0.01 & -0.11 & 0.06 & 1.20 & 0.12 & 0.40 \\
\hline Earnings & 2 & -0.15 & -2.84 & 0.06 & 1.20 & 0.09 & 0.87 & -0.08 & -1.08 & 0.22 & 0.81 \\
\hline General & 2 & 0.01 & 0.90 & -0.01 & -1.06 & 0.18 & 4.90 & 0.03 & 1.60 & -0.11 & -1.03 \\
\hline WPA & 2 & 0.01 & 0.96 & 0.00 & 0.21 & 0.05 & 2.78 & 0.21 & 5.33 & 0.02 & 0.97 \\
\hline CWA & 2 & 0.00 & 0.39 & 0.00 & -0.92 & 0.00 & 0.52 & 0.00 & 0.00 & -0.34 & -3.64 \\
\hline Employment & 3 & 0.06 & 1.87 & -0.01 & -0.39 & 0.24 & 2.50 & 0.03 & 0.50 & 0.55 & 1.25 \\
\hline Earnings & 3 & 0.00 & 0.04 & -0.02 & -0.77 & 0.07 & 0.65 & -0.01 & -0.17 & -0.12 & -0.46 \\
\hline General & 3 & 0.00 & -0.11 & 0.01 & 1.27 & 0.07 & 2.86 & 0.00 & 0.25 & -0.01 & -0.09 \\
\hline WPA & 3 & 0.00 & -0.34 & -0.01 & -1.10 & 0.03 & 1.79 & 0.01 & 0.16 & 0.00 & 0.13 \\
\hline CWA & 3 & 0.00 & -2.58 & 0.00 & 0.07 & 0.00 & -0.22 & 0.00 & -0.71 & -0.08 & -1.16 \\
\hline Employment & 4 & -0.01 & -0.41 & 0.00 & 0.07 & 0.05 & 0.56 & -0.02 & -0.43 & -0.57 & -1.40 \\
\hline Earnings & 4 & -0.05 & -1.79 & 0.05 & 1.58 & -0.10 & -0.98 & -0.03 & -0.52 & -0.15 & -0.58 \\
\hline General & 4 & 0.00 & -0.05 & 0.00 & 0.67 & 0.03 & 0.89 & 0.00 & 0.02 & 0.03 & 0.42 \\
\hline WPA & 4 & 0.00 & -0.48 & 0.00 & 0.11 & 0.06 & 2.11 & -0.08 & -2.15 & 0.00 & -0.21 \\
\hline CWA & 4 & 0.00 & -0.45 & 0.00 & 1.66 & 0.00 & -0.32 & 0.00 & -1.26 & 0.12 & 3.10 \\
\hline Employment & 5 & 0.00 & -0.01 & 0.01 & 0.23 & 0.08 & 1.14 & 0.01 & 0.14 & -0.07 & -0.21 \\
\hline Earnings & 5 & 0.05 & 1.57 & 0.01 & 0.30 & 0.09 & 0.92 & 0.01 & 0.15 & 0.10 & 0.37 \\
\hline General & 5 & 0.01 & 1.82 & 0.00 & -0.74 & -0.03 & -1.19 & 0.00 & -0.04 & -0.02 & -0.34 \\
\hline WPA & 5 & 0.00 & 0.34 & 0.00 & -0.03 & -0.04 & -1.53 & 0.09 & 2.05 & -0.02 & -0.75 \\
\hline CWA & 5 & 0.00 & 1.54 & 0.00 & -0.59 & -0.01 & -1.74 & 0.00 & -0.87 & -0.10 & -3.24 \\
\hline Employment & 6 & 0.08 & 2.71 & 0.02 & 0.57 & -0.06 & -0.78 & 0.04 & 0.72 & 0.03 & 0.11 \\
\hline Earnings & 6 & -0.02 & -0.54 & 0.08 & 2.79 & 0.02 & 0.15 & 0.01 & 0.15 & 0.39 & 1.51 \\
\hline General & 6 & 0.00 & -0.52 & 0.00 & 0.49 & 0.00 & 0.01 & -0.01 & -0.79 & -0.02 & -0.29 \\
\hline WPA & 6 & 0.01 & 0.77 & 0.01 & 1.45 & -0.01 & -0.32 & -0.02 & -0.44 & 0.00 & 0.02 \\
\hline CWA & 6 & 0.00 & -1.76 & 0.00 & 0.50 & 0.00 & -0.58 & 0.00 & -0.26 & 0.10 & 3.97 \\
\hline Employment & 7 & -0.04 & -1.34 & 0.03 & 1.20 & 0.13 & 1.48 & 0.04 & 0.80 & -0.02 & -0.07 \\
\hline Earnings & 7 & -0.01 & -0.31 & -0.04 & -1.38 & 0.02 & 0.23 & 0.04 & 0.63 & 0.62 & 1.74 \\
\hline General & 7 & 0.00 & -0.32 & 0.00 & -0.96 & 0.01 & 0.52 & -0.01 & -0.43 & -0.05 & -1.11 \\
\hline WPA & 7 & 0.01 & 0.86 & 0.00 & 0.37 & 0.00 & -0.10 & -0.05 & -1.34 & -0.02 & -0.60 \\
\hline CWA & 7 & 0.00 & 0.26 & 0.00 & -0.05 & 0.00 & 0.64 & 0.00 & -0.76 & 0.05 & 2.46 \\
\hline Employment & 8 & -0.03 & -1.03 & -0.04 & -1.50 & -0.10 & -1.00 & -0.03 & -0.48 & -0.28 & -1.06 \\
\hline Earnings & 8 & -0.01 & -0.51 & -0.05 & -1.88 & 0.03 & 0.28 & 0.03 & 0.38 & -0.27 & -0.71 \\
\hline General & 8 & 0.00 & 0.10 & 0.00 & 0.30 & -0.02 & -0.59 & -0.01 & -0.57 & -0.08 & -1.69 \\
\hline WPA & 8 & 0.00 & -0.10 & 0.00 & -0.09 & 0.00 & 0.23 & 0.01 & 0.15 & -0.02 & -0.67 \\
\hline CWA & 8 & 0.00 & 0.56 & 0.00 & -2.66 & -0.01 & -1.15 & 0.00 & -0.63 & 0.01 & 0.90 \\
\hline Employment & 9 & 0.00 & 0.00 & 0.00 & 0.06 & -0.03 & -0.38 & 0.02 & 0.32 & -0.04 & -0.16 \\
\hline Earnings & 9 & 0.00 & 0.02 & 0.02 & 1.10 & -0.04 & -0.53 & -0.02 & -0.31 & -0.48 & -1.81 \\
\hline General & 9 & 0.00 & -0.99 & 0.00 & -0.16 & 0.00 & 0.13 & 0.01 & 1.00 & 0.07 & 1.20 \\
\hline WPA & 9 & -0.01 & -1.56 & 0.00 & -0.51 & 0.00 & 0.01 & 0.01 & 0.23 & 0.00 & -0.18 \\
\hline CWA & 9 & 0.00 & 1.43 & 0.00 & -0.23 & 0.01 & 1.54 & 0.00 & 0.35 & 0.08 & 7.30 \\
\hline $\mathrm{N}$ & & & & & & & & & & & \\
\hline
\end{tabular}


Table C.6

Panel VAR Coefficient Results-Specification 5

\begin{tabular}{cccccccc}
\hline & \multicolumn{6}{c}{ Employment } & \multicolumn{2}{c}{ Earnings } & \multicolumn{2}{c}{ Relief } \\
Independent Variable & Lag & Beta & t-statistic & Beta & t-statistic & Beta & t-statistic \\
\hline Employment & 1 & 0.80 & 12.94 & 0.04 & 1.15 & -0.21 & -5.48 \\
Earnings & 1 & 0.21 & 4.42 & 0.82 & 14.03 & -0.10 & -2.42 \\
Relief & 1 & -0.02 & -2.57 & 0.01 & 0.96 & 0.62 & 14.73 \\
Employment & 2 & -0.01 & -0.10 & -0.06 & -2.15 & 0.06 & 1.51 \\
Earnings & 2 & -0.14 & -2.84 & 0.06 & 1.12 & -0.01 & -0.21 \\
Relief & 2 & 0.01 & 1.42 & 0.00 & -0.43 & 0.25 & 6.75 \\
Employment & 3 & 0.07 & 1.99 & -0.01 & -0.38 & 0.09 & 1.98 \\
Earnings & 3 & 0.00 & -0.05 & -0.02 & -0.75 & 0.03 & 0.55 \\
Relief & 3 & 0.00 & -0.20 & 0.00 & 0.16 & 0.05 & 1.85 \\
Employment & 4 & -0.01 & -0.30 & 0.00 & 0.12 & 0.00 & -0.10 \\
Earnings & 4 & -0.05 & -1.69 & 0.05 & 1.49 & -0.05 & -0.85 \\
Relief & 4 & -0.01 & -0.46 & 0.00 & 0.20 & -0.02 & -0.86 \\
Employment & 5 & 0.00 & -0.15 & 0.01 & 0.19 & 0.02 & 0.48 \\
Earnings & 5 & 0.05 & 1.64 & 0.01 & 0.27 & 0.03 & 0.55 \\
Relief & 5 & 0.02 & 1.66 & -0.01 & -0.68 & 0.01 & 0.27 \\
Employment & 6 & 0.07 & 2.50 & 0.02 & 0.55 & -0.02 & -0.44 \\
Earnings & 6 & -0.02 & -0.72 & 0.08 & 2.83 & 0.02 & 0.42 \\
Relief & 6 & 0.00 & 0.17 & 0.01 & 1.40 & 0.01 & 0.27 \\
Employment & 7 & -0.04 & -1.23 & 0.04 & 1.23 & 0.08 & 1.78 \\
Earnings & 7 & -0.01 & -0.30 & -0.04 & -1.39 & 0.02 & 0.28 \\
Relief & 7 & 0.01 & 0.79 & 0.00 & 0.21 & -0.03 & -1.14 \\
Employment & 8 & -0.02 & -0.76 & -0.04 & -1.49 & -0.04 & -0.90 \\
Earnings & 8 & -0.01 & -0.40 & -0.05 & -1.91 & 0.03 & 0.50 \\
Relief & 8 & 0.00 & -0.44 & 0.00 & 0.07 & -0.01 & -0.55 \\
Employment & 9 & -0.01 & -0.29 & 0.00 & 0.06 & -0.01 & -0.19 \\
Earnings & 9 & 0.00 & -0.06 & 0.02 & 1.11 & 0.00 & -0.01 \\
Relief & 9 & -0.02 & -2.06 & -0.01 & -1.22 & 0.02 & 1.24 \\
\hline N & & & & & 3139 & & \\
\hline & & & & & & &
\end{tabular}


Table C.7

Panel VAR Coefficient Results-Specification 6

\begin{tabular}{|c|c|c|c|c|c|c|c|c|c|}
\hline \multirow[b]{3}{*}{ Independent Variable } & \multirow[b]{3}{*}{ Lag } & \multicolumn{8}{|c|}{ Dependent Variable } \\
\hline & & \multicolumn{2}{|c|}{ Employment } & \multicolumn{2}{|c|}{ Earnings } & \multicolumn{2}{|c|}{ General } & \multicolumn{2}{|c|}{ WPA } \\
\hline & & Beta & t-statistic & Beta & t-statistic & Beta & t-statistic & Beta & t-statistic \\
\hline Employment & 1 & 0.80 & 13.02 & 0.04 & 1.16 & -0.26 & -3.42 & -0.15 & -3.23 \\
\hline Earnings & 1 & 0.20 & 4.42 & 0.82 & 13.98 & -0.23 & -3.27 & 0.00 & -0.05 \\
\hline General & 1 & -0.01 & -1.71 & 0.00 & 0.71 & 0.57 & 13.27 & 0.00 & -0.27 \\
\hline WPA & 1 & -0.01 & -1.43 & 0.00 & 0.45 & -0.10 & -5.83 & 0.72 & 19.12 \\
\hline Employment & 2 & -0.01 & -0.09 & -0.06 & -2.15 & 0.01 & 0.06 & 0.06 & 1.20 \\
\hline Earnings & 2 & -0.15 & -2.86 & 0.06 & 1.13 & 0.10 & 0.97 & -0.08 & -1.07 \\
\hline General & 2 & 0.01 & 1.03 & 0.00 & -0.97 & 0.17 & 4.79 & 0.03 & 1.60 \\
\hline WPA & 2 & 0.01 & 0.97 & 0.00 & 0.23 & 0.05 & 2.78 & 0.21 & 5.33 \\
\hline Employment & 3 & 0.07 & 1.96 & -0.01 & -0.40 & 0.22 & 2.25 & 0.03 & 0.48 \\
\hline Earnings & 3 & 0.00 & 0.03 & -0.03 & -0.79 & 0.08 & 0.79 & -0.01 & -0.16 \\
\hline FERA & 3 & 0.00 & -0.09 & 0.01 & 1.25 & 0.07 & 2.85 & 0.00 & 0.26 \\
\hline WPA & 3 & 0.00 & -0.31 & -0.01 & -1.10 & 0.03 & 1.74 & 0.01 & 0.16 \\
\hline Employment & 4 & -0.01 & -0.26 & 0.00 & 0.12 & 0.04 & 0.45 & -0.02 & -0.43 \\
\hline Earnings & 4 & -0.05 & -1.70 & 0.05 & 1.54 & -0.10 & -0.97 & -0.03 & -0.53 \\
\hline General & 4 & 0.00 & -0.24 & 0.00 & 0.56 & 0.03 & 0.92 & 0.00 & 0.01 \\
\hline WPA & 4 & 0.00 & -0.50 & 0.00 & 0.09 & 0.06 & 2.10 & -0.08 & -2.15 \\
\hline Employment & 5 & 0.00 & -0.14 & 0.01 & 0.25 & 0.09 & 1.23 & 0.01 & 0.16 \\
\hline Earnings & 5 & 0.05 & 1.64 & 0.01 & 0.29 & 0.09 & 0.93 & 0.01 & 0.17 \\
\hline General & 5 & 0.01 & 1.73 & 0.00 & -0.69 & -0.03 & -1.12 & 0.00 & -0.06 \\
\hline WPA & 5 & 0.00 & 0.29 & 0.00 & -0.04 & -0.04 & -1.51 & 0.09 & 2.05 \\
\hline Employment & 6 & 0.07 & 2.50 & 0.02 & 0.51 & -0.06 & -0.77 & 0.04 & 0.72 \\
\hline Earnings & 6 & -0.02 & -0.65 & 0.08 & 2.87 & 0.02 & 0.18 & 0.01 & 0.16 \\
\hline General & 6 & 0.00 & -0.18 & 0.00 & 0.45 & 0.00 & -0.11 & -0.01 & -0.81 \\
\hline WPA & 6 & 0.01 & 0.77 & 0.01 & 1.45 & -0.01 & -0.31 & -0.02 & -0.44 \\
\hline Employment & 7 & -0.03 & -1.20 & 0.03 & 1.17 & 0.13 & 1.48 & 0.04 & 0.79 \\
\hline Earnings & 7 & -0.01 & -0.30 & -0.04 & -1.37 & 0.02 & 0.18 & 0.04 & 0.62 \\
\hline General & 7 & 0.00 & -0.36 & 0.00 & -0.88 & 0.01 & 0.49 & -0.01 & -0.41 \\
\hline WPA & 7 & 0.01 & 0.90 & 0.00 & 0.37 & 0.00 & -0.11 & -0.05 & -1.34 \\
\hline Employment & 8 & -0.02 & -0.79 & -0.04 & -1.55 & -0.10 & -1.01 & -0.02 & -0.46 \\
\hline Earnings & 8 & -0.01 & -0.48 & -0.05 & -1.98 & 0.02 & 0.17 & 0.03 & 0.37 \\
\hline General & 8 & 0.00 & -0.08 & 0.00 & 0.44 & -0.01 & -0.49 & -0.01 & -0.57 \\
\hline WPA & 8 & 0.00 & -0.09 & 0.00 & -0.07 & 0.00 & 0.25 & 0.01 & 0.15 \\
\hline Employment & 9 & 0.00 & -0.23 & 0.00 & 0.17 & -0.02 & -0.23 & 0.02 & 0.36 \\
\hline Earnings & 9 & 0.00 & -0.09 & 0.03 & 1.17 & -0.04 & -0.44 & -0.02 & -0.31 \\
\hline General & 9 & 0.00 & -0.96 & 0.00 & -0.36 & 0.00 & 0.12 & 0.01 & 1.01 \\
\hline WPA & 9 & -0.01 & -1.60 & 0.00 & -0.51 & 0.00 & 0.05 & 0.01 & 0.23 \\
\hline $\mathrm{N}$ & & & & & & & & & \\
\hline
\end{tabular}


Table C.8

Panel VAR Coefficient Results-Specification 7

\begin{tabular}{|c|c|c|c|c|c|c|c|}
\hline \multirow[b]{3}{*}{ Independent Variable } & \multirow[b]{3}{*}{ Lag } & \multicolumn{6}{|c|}{ Dependent Variable } \\
\hline & & \multicolumn{2}{|c|}{ Employment } & \multicolumn{2}{|c|}{ Earnings } & \multicolumn{2}{|c|}{ Relief } \\
\hline & & Beta & t-statistic & Beta & t-statistic & Beta & t-statistic \\
\hline Employment & 1 & 0.71 & 9.71 & 0.14 & 3.26 & -0.23 & -1.97 \\
\hline Earnings & 1 & 0.25 & 4.03 & 0.55 & 6.80 & -0.26 & -2.72 \\
\hline Relief & 1 & -0.02 & -1.21 & 0.00 & 0.09 & 0.49 & 10.70 \\
\hline Employment & 2 & -0.01 & -0.18 & -0.04 & -0.90 & -0.06 & -0.49 \\
\hline Earnings & 2 & -0.13 & -2.22 & 0.06 & 1.05 & 0.09 & 0.74 \\
\hline Relief & 2 & 0.01 & 0.78 & 0.00 & 0.08 & 0.16 & 3.59 \\
\hline Employment & 3 & 0.10 & 1.70 & -0.03 & -0.62 & 0.23 & 1.78 \\
\hline Earnings & 3 & 0.00 & 0.08 & -0.02 & -0.37 & 0.03 & 0.24 \\
\hline Relief & 3 & -0.01 & -0.66 & 0.00 & 0.02 & 0.10 & 2.43 \\
\hline Employment & 4 & -0.08 & -1.96 & -0.03 & -0.81 & -0.01 & -0.07 \\
\hline Earnings & 4 & -0.06 & -1.39 & -0.06 & -1.20 & -0.12 & -0.93 \\
\hline Relief & 4 & 0.00 & -0.19 & 0.02 & 0.88 & -0.01 & -0.28 \\
\hline Employment & 5 & -0.08 & -1.95 & -0.04 & -0.78 & 0.03 & 0.26 \\
\hline Earnings & 5 & 0.00 & 0.09 & 0.00 & -0.05 & 0.04 & 0.36 \\
\hline Relief & 5 & 0.02 & 0.93 & -0.02 & -1.02 & -0.08 & -1.85 \\
\hline Employment & 6 & 0.04 & 0.91 & 0.03 & 0.59 & -0.11 & -1.14 \\
\hline Earnings & 6 & -0.01 & -0.34 & 0.07 & 1.51 & 0.17 & 1.45 \\
\hline Relief & 6 & 0.00 & 0.01 & 0.00 & 0.01 & -0.02 & -0.37 \\
\hline Employment & 7 & 0.05 & 1.27 & 0.04 & 1.14 & 0.15 & 1.28 \\
\hline Earnings & 7 & -0.03 & -0.54 & -0.10 & -2.08 & 0.00 & -0.02 \\
\hline Relief & 7 & 0.00 & 0.10 & 0.01 & 0.69 & 0.04 & 0.79 \\
\hline Employment & 8 & 0.02 & 0.53 & 0.05 & 0.95 & -0.12 & -0.82 \\
\hline Earnings & 8 & 0.02 & 0.55 & 0.03 & 0.56 & 0.08 & 0.61 \\
\hline Relief & 8 & 0.00 & 0.14 & 0.01 & 0.53 & -0.02 & -0.46 \\
\hline Employment & 9 & -0.05 & -1.46 & -0.02 & -0.56 & 0.00 & -0.03 \\
\hline Earnings & 9 & -0.03 & -0.67 & -0.02 & -0.53 & -0.17 & -1.51 \\
\hline Relief & 9 & 0.00 & 0.22 & 0.00 & 0.10 & -0.04 & -0.92 \\
\hline $\mathrm{N}$ & & & & & 873 & & \\
\hline
\end{tabular}




\section{Impulse Response Functions from other Specifications}

Figure C.1

Impulse Responses-Specification 4

Response of Employment to Response of Employment to Response of Employment to
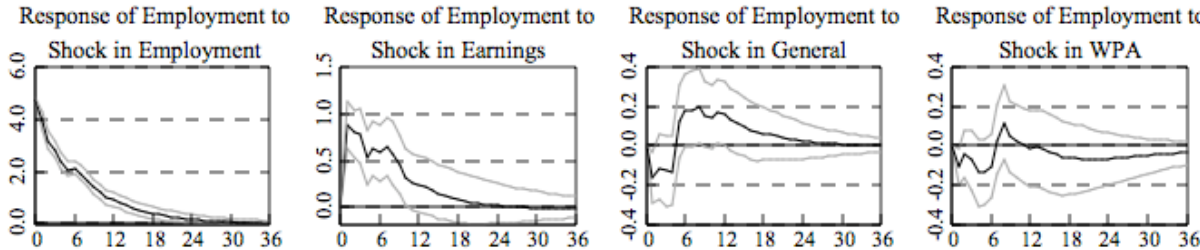

Response of Employment to

Response of Earnings to

Response of Earnings to

Response of Earnings to

Response of Earnings to
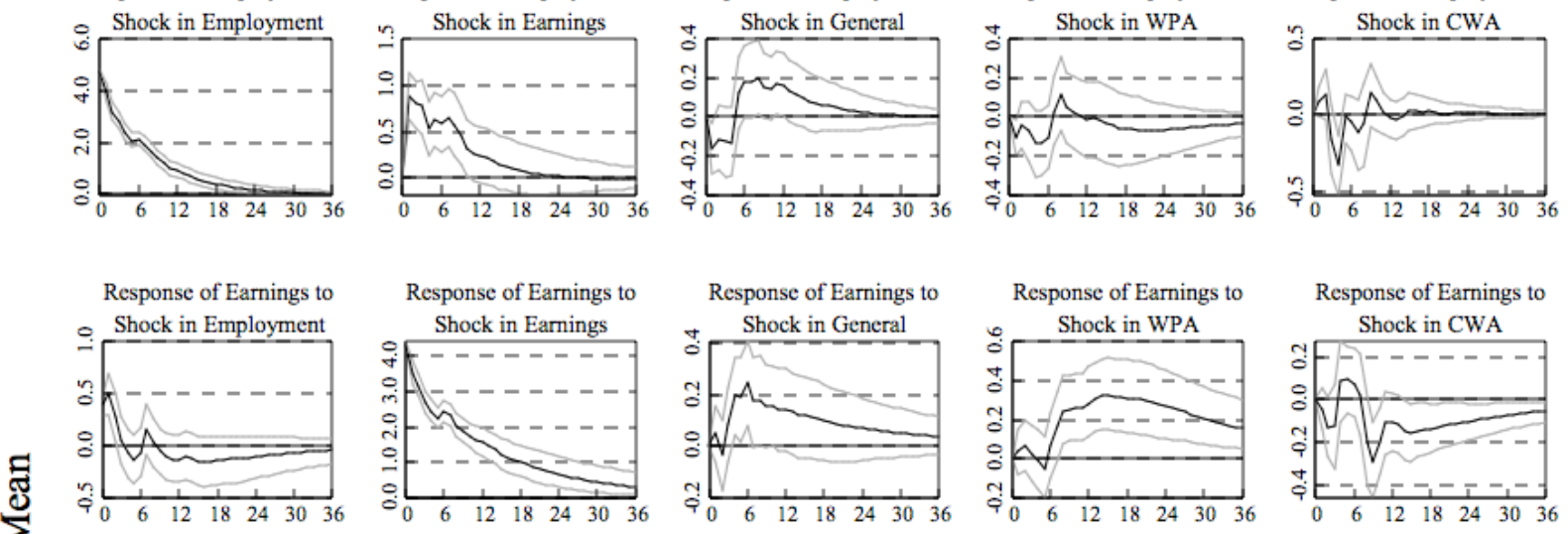

Shock in Earnings
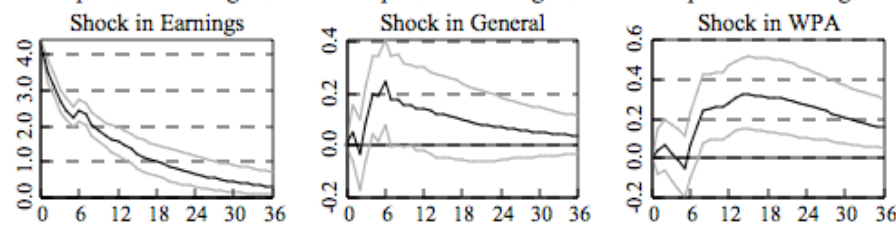

Response of Earnings to

हే

Response of General to
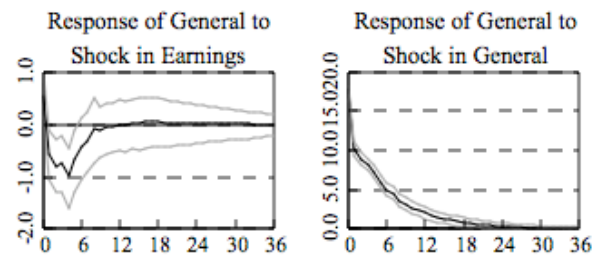

Response of General to
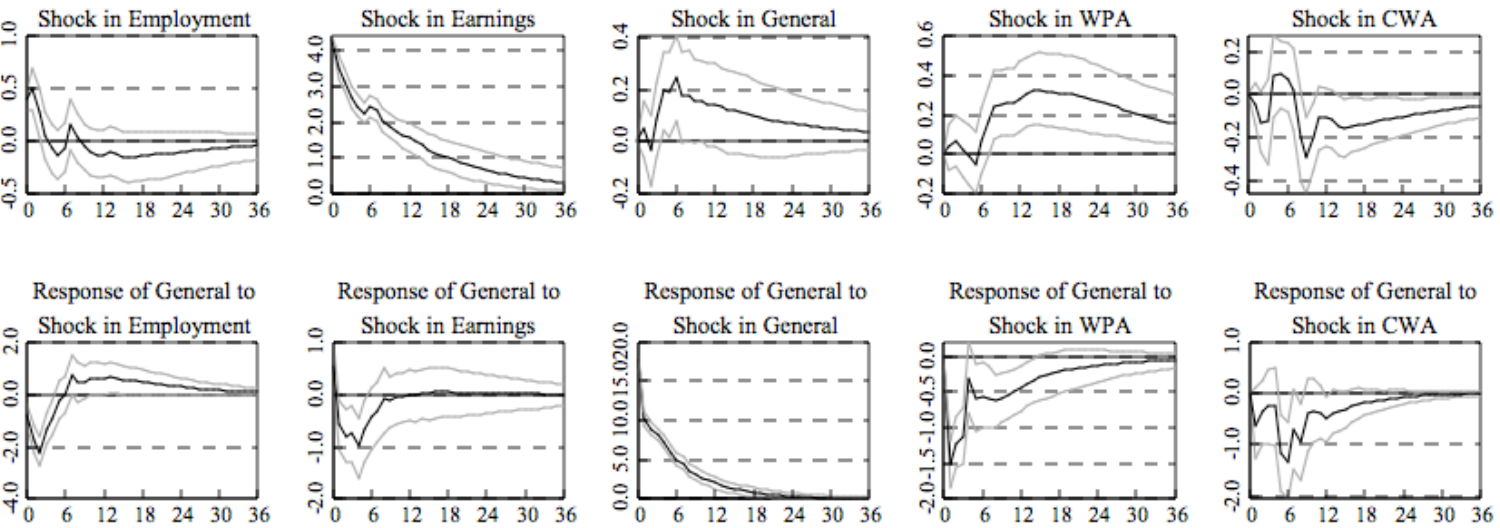

Shock in WPA

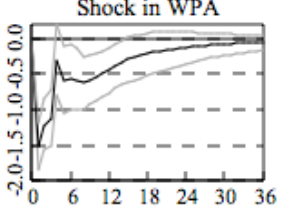

Response of General to

Response of WPA to
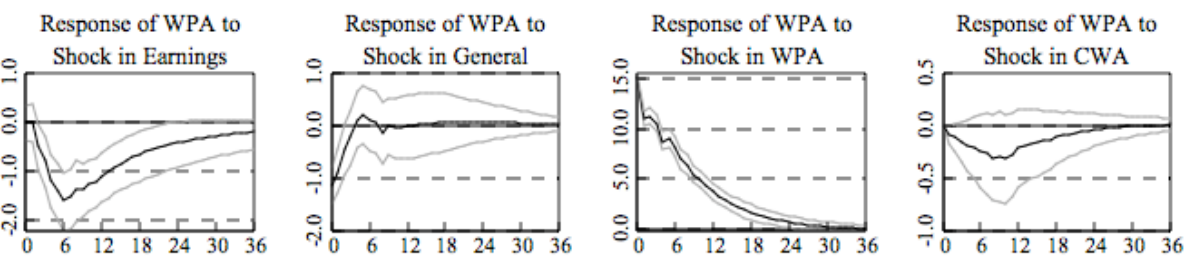

Response of CWA to
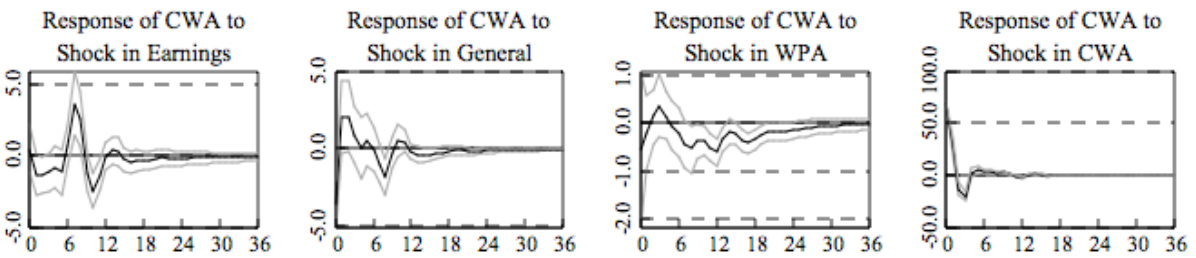

Months after Shock 
Figure C.2

Impulse Responses-Specification 5

Response of Employment to Response of Employment to

- Shock in Employment

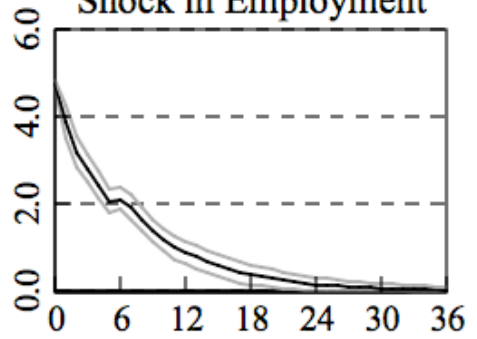

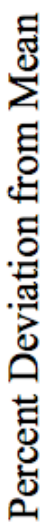
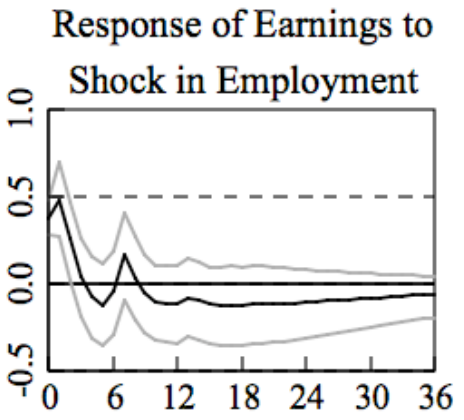

Response of Relief to

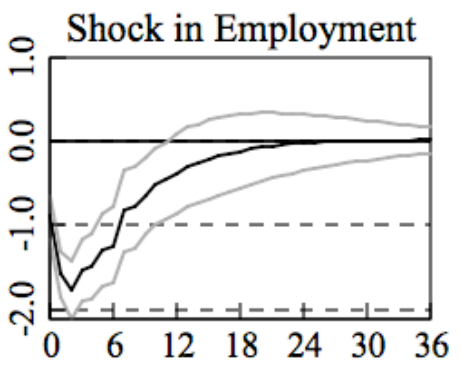

Shock in Earnings

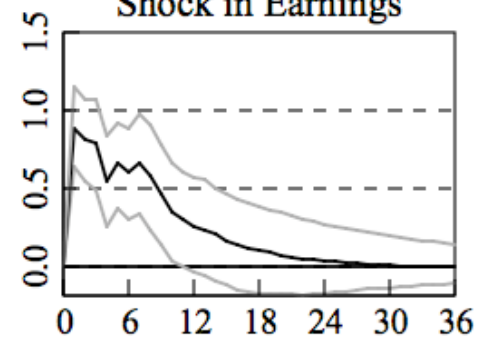

Response of Earnings to Shock in Earnings

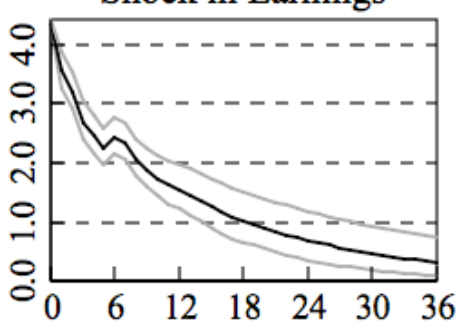

Response of Relief to

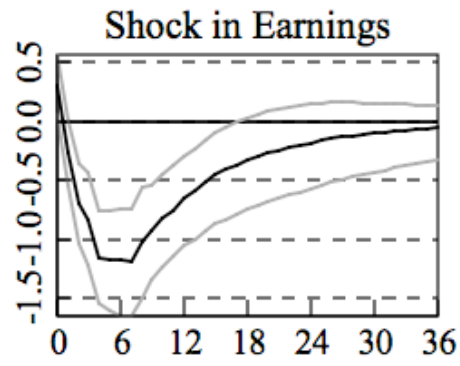

Months after Shock
Response of Employment to

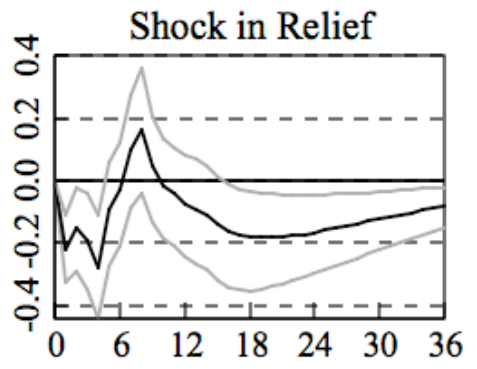

Response of Earnings to

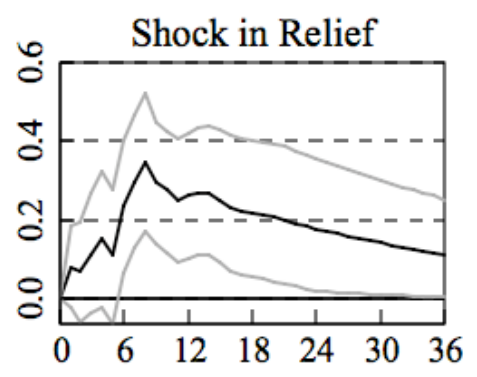

Response of Relief to

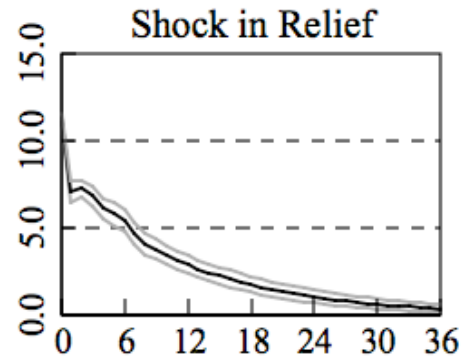


Figure C.3

Impulse Responses-Specification 6

Response of Employment to Response of Employment to

Response of Employment to

Response of Employment to
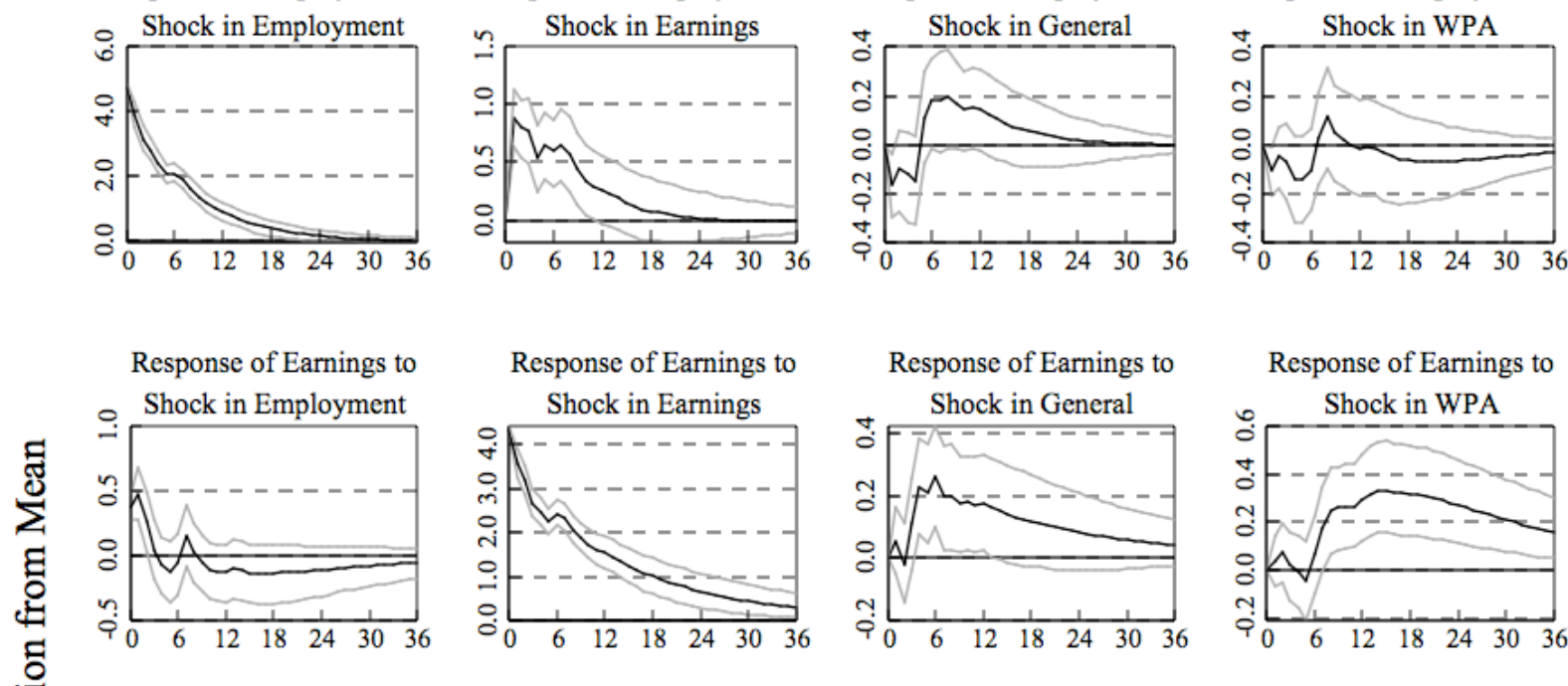

Response of Earnings to

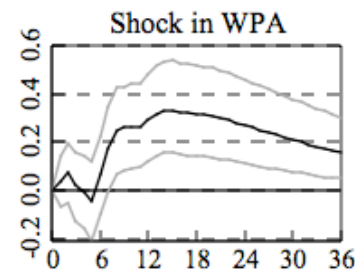

Response of General to
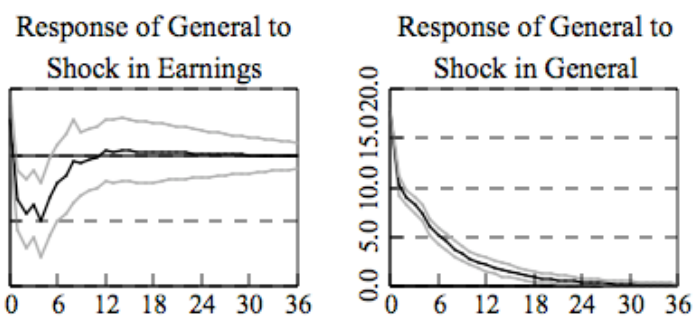

Response of General to Shock in WPA
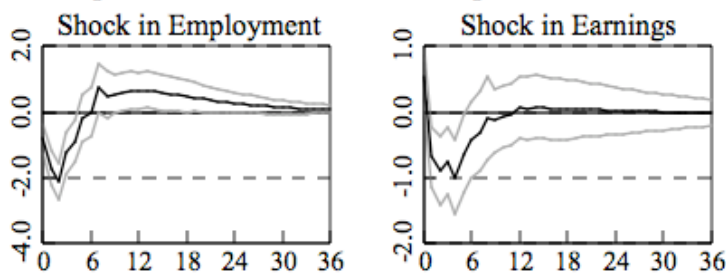

Response of WPA to Shock in Employment
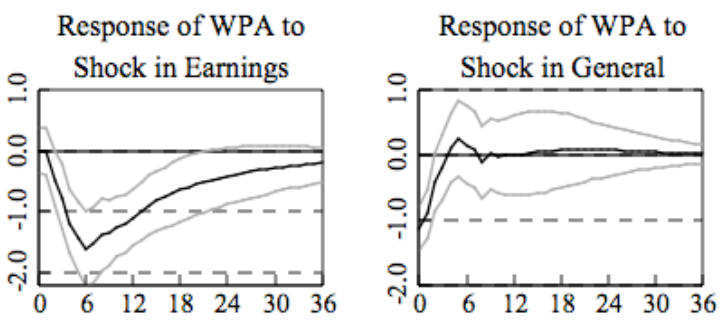

Response of WPA to

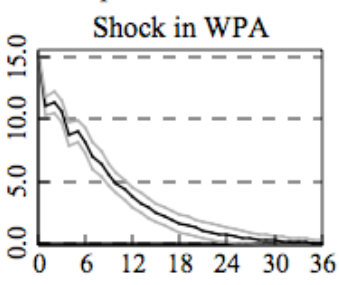

\section{Months after Shock}


Figure C.4

Impulse Responses-Specification 7

Response of Employment to Response of Employment to
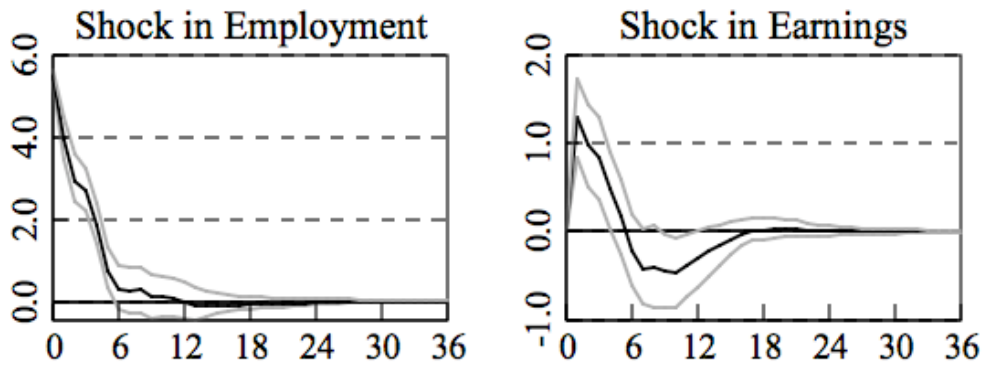

Response of Employment to

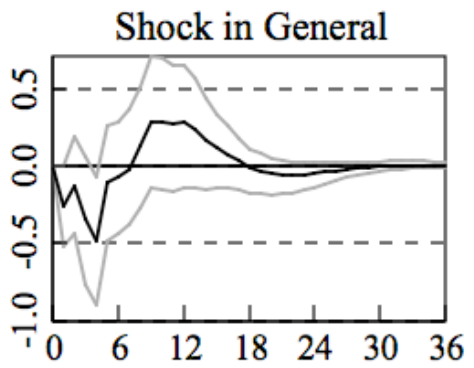

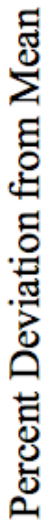
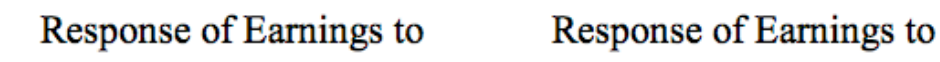

\section{Response of Earnings to}
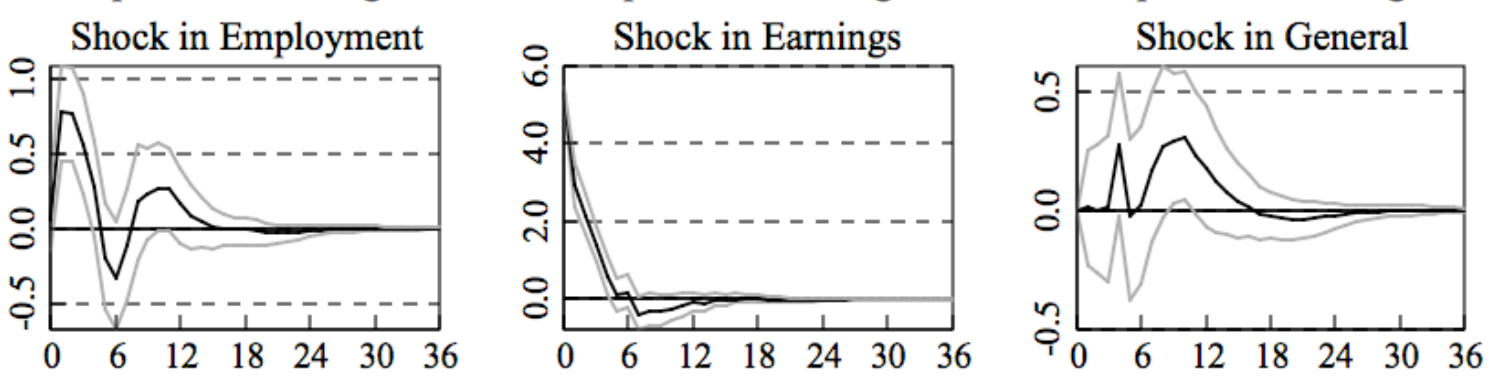

\section{Response of General to}
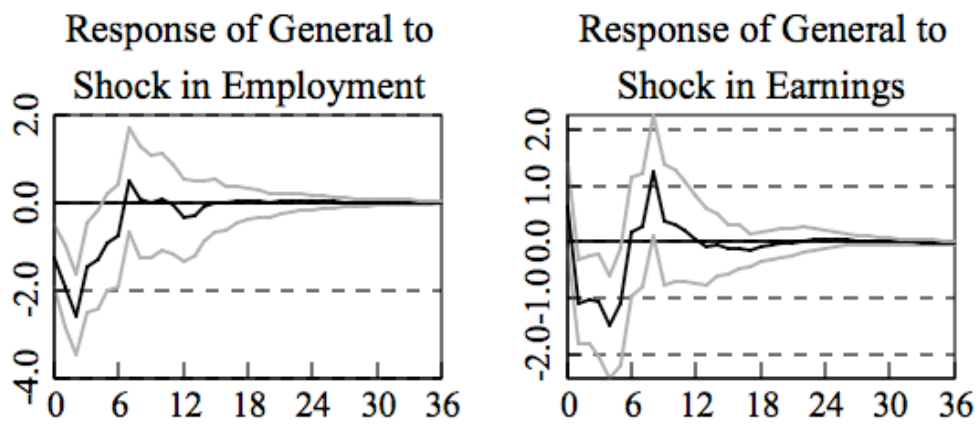

Response of General to

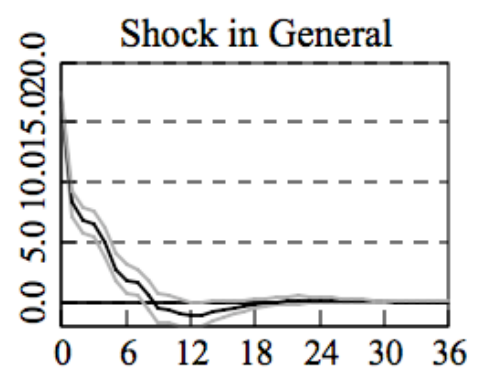

Months after Shock 


\section{Appendix D.}

\section{Discussion of Implications of Linked Relative Employment Index}

The linked relative employment index will not capture changes in employment caused by firm entry or exit. Consider the following equation.

$$
\delta E=\delta M E+E n t r y-E x i t
$$

The true change in total employment, $\delta E$ is made up of the change in measured employment, $\delta M E$ among firms operating in both periods and increases in employment due to entry, Entry, less decreases due to exit, Exit. The change in measured employment will be greater than the true change if there is net employer exit, a situation where the employment decline from firms exiting more than offsets the employment rise from firms entering. Similarly, the change in measured employment will be less than the true change if there is net employer entry, a situation where the employment rise from firms entering more than offsets the employment decline from firms exiting.

$$
\begin{aligned}
& \text { If net entry: } \delta M E<\delta E \\
& \text { If net exit: } \delta M E>\delta E
\end{aligned}
$$

The above conditions imply that measured changes in employment may result in the index understating or overstating the magnitude of changes. It may also misstate the direction of changes in employment. The following 3 cases detail under what conditions each will hold.

Case 1: Measured employment understates the magnitude of the change in total employment.

If $\delta M E<0 \&$ net exit: $\delta E$ more negative If $\delta M E>0 \&$ net entry: $\delta E$ more positive

Understatement will occur if changes in measured and unmeasured employment have the same sign. This is more likely to occur when a labor market experiences a general rise or decline across all sectors and there are firms on the margin of entry and exit. In the case of a negative 
shock, this will happen when some firms fire or lay off workers while other firms close down completely. In an upturn some firms add workers while new firms are created.

Case 2: Measured employment overstates the magnitude of the change in total employment.

If $\delta M E<0 \&$ net entry $\&|\delta M E|>\mid$ net entry $\mid: \delta E$ less negative but negative If $\delta M E>0 \&$ net exit $\&|\delta M E|>\mid$ net exit $\mid: \delta E$ less positive but positive

Overstatement will occur if changes in measured and unmeasured employment occur in opposite directions but the size of the change in measured employment is larger than the size of the change in unmeasured employment. In situations where there are citywide shocks to the labor market in the same direction, this seems less likely. Such overstatement is possible if specific labor sectors experiencing a shock driven by local city changes while there are sectors that are influenced by shocks from external sources in the opposite direction. As an example, say the firms that rely on local demand experience a decline in demand due to a city-wide downturn that leads to layoffs and some exit. Meanwhile, new firms open and hire workers to produce a new product for which there is growing demand in other parts of the country. If the new firms in the opening industry hire more workers than the exiting firms lost but not enough new workers to also offset the lost jobs with continuing firms, the measured employment will overstate the magnitude of the change in total employment.

Case 3: Measured employment misstates the direction of the change in total employment.

If $\delta M E<0 \&$ net entry $\&|\delta M E|<\mid$ net entry $\mid: \delta E$ positive If $\delta M E>0 \&$ net exit $\&|\delta M E|<\mid$ net entry $\mid: \delta E$ negative

Misstatement will occur if changes in measured and unmeasured employment occur in opposite directions and the size of the change in measured employment is less than the size of the change in unmeasured employment. This is possible under the same conditions as Case 2, however it implies that the fluctuations in employment are due more to firms entering and exiting rather than existing firms hiring and firing. In the example under case two, this would 
occur when the new firms in the opening industry hire more workers than the combination of jobs lost from firms exiting and from continuing firms laying off or firing workers.

In general, it is our intuition that the more that employers within the city experience shocks to the labor market that are similar across all firms and sectors, the more likely it will be that the measured employment will understate fluctuations in employment. The more heterogeneous the shocks across employers and sectors within the city, the more likely cases 2 and 3 will arise.

To get a sense of the size of the problem caused by the absence of information on entering and exiting jobs, Figures D.1-D.2 chart the measured linked-relative index and what would be the true employment index for Los Angeles under different assumptions about the magnitude and direction of unmeasured employment. The "true" percent change in employment in a given period is created using the following formula.

$$
\begin{aligned}
& \quad \% \delta \hat{E}_{i t}=\% \delta M E_{i t}+\% \delta M E_{i t} \cdot R V_{i t} \\
& \text { where } R V \quad U(0.25,0.75)
\end{aligned}
$$

We take the measured percent change in employment in a given month $(M E)$ and multiply it times a uniformly distributed random variable with a mean of 0.50 . This is much larger than the approximate 10 percent seen in the study by Pivetz, Searson, and Spletzer (2001). In other words, if the measured change in employment between months $t$ and $t+1$ is positive 10 percent we multiply 10 times the random variable. This makes the magnitude of the unmeasured change in employment on average 5 percent during that month. Consequently, on average the total real change is then 15 percent if there was a net increase in unmeasured employment or 5 percent if there is net fall in unmeasured employment. This "true" percent change in employment is then used to construct the linked relative employment index.

In both figures the black line is the actual measured employment index expressed as the percent deviation from the 1932 to 1939 mean just as in Figure 1. The solid grey line is the "true" employment index created by taking the mean from 1,000 Monte-Carlo simulations. The dashed grey lines represent the 95 percent confidence interval around this mean. 
Figure D.1

Case 1: Linked-Relative Index Under Measures Employment Changes

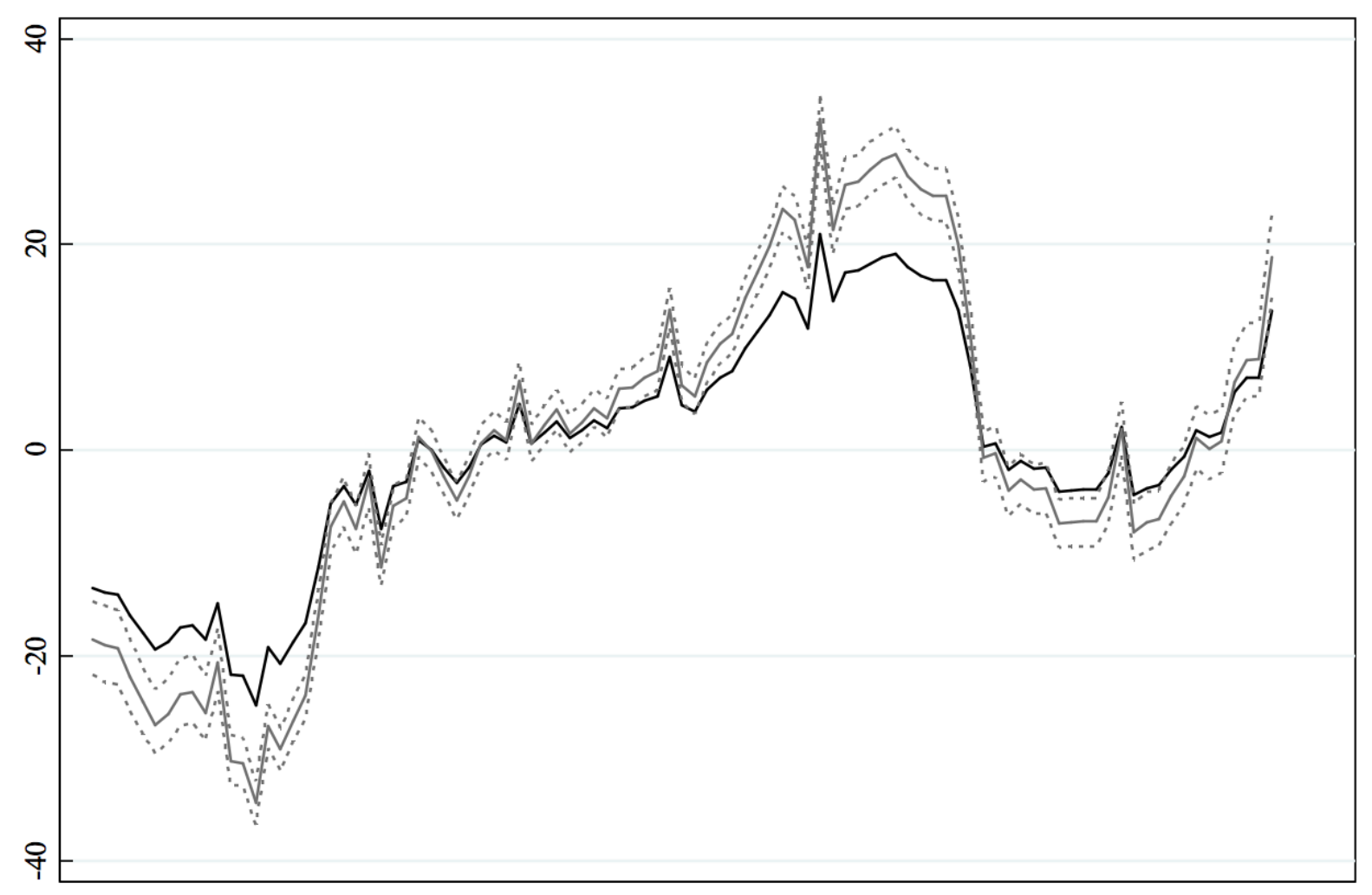

The size of the difference between the true employment measure and the one recorded by the linked relative employment index is larger proportionately the further the employment measure is from its mean. This should be expected since if the mis-measurement always overstates (under-states) the true change the effect will accumulate over time. In both Cases 1 and 2 at its largest the difference between the true employment measure and the measured one is approximately 10 percentage points. We see these as extreme scenarios because it is likely that there will be a mixture of under- and over-statements of the true change over time. 
Figure D. 2

Case 1: Linked-Relative Index Over Measures Employment Changes

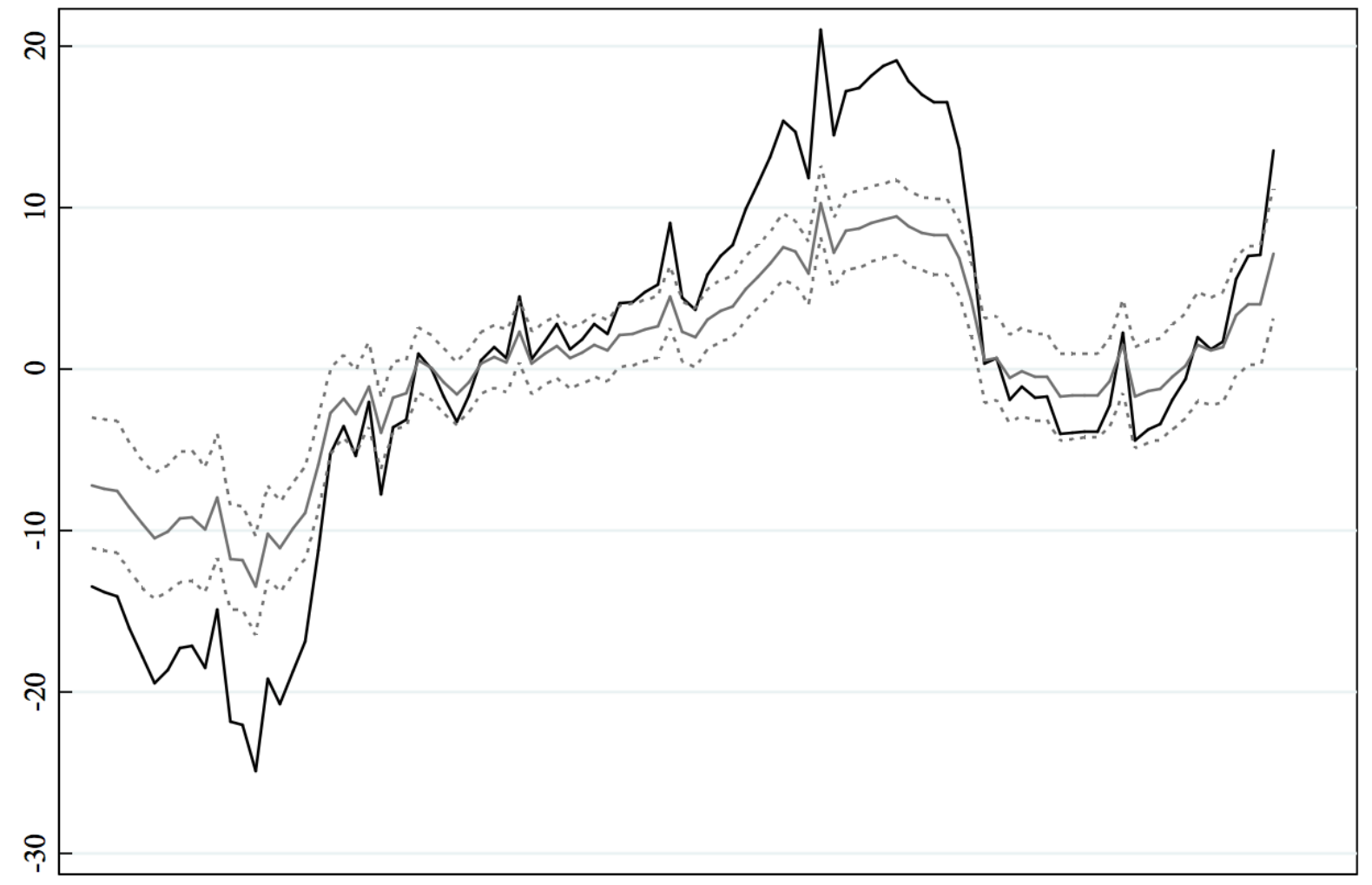

In the context of the VAR model it is difficult to try and sign the bias that might be created by the type of measurement error found in cases 1 and 2. We can, however, use the procedure above to estimate "true" changes in employment and see how our results change when this measure is used. ${ }^{37}$ As one can see from Figures D.3 and D.4 when this is done the shape of IRFs are change little though the magnitude in the response of employment to relief is decreased in absolute value.

\footnotetext{
${ }^{37}$ Note that we leave the earnings index unchanged, implicitly assuming that measured payroll and employment can still be used to construct an unbiased monthly earnings index.
} 
Figure D.3

Impulse Responses-Specification 1 Linked-Relative Index Under Measures Employment Changes

Response of Employment to Response of Employment to Response of Employment to
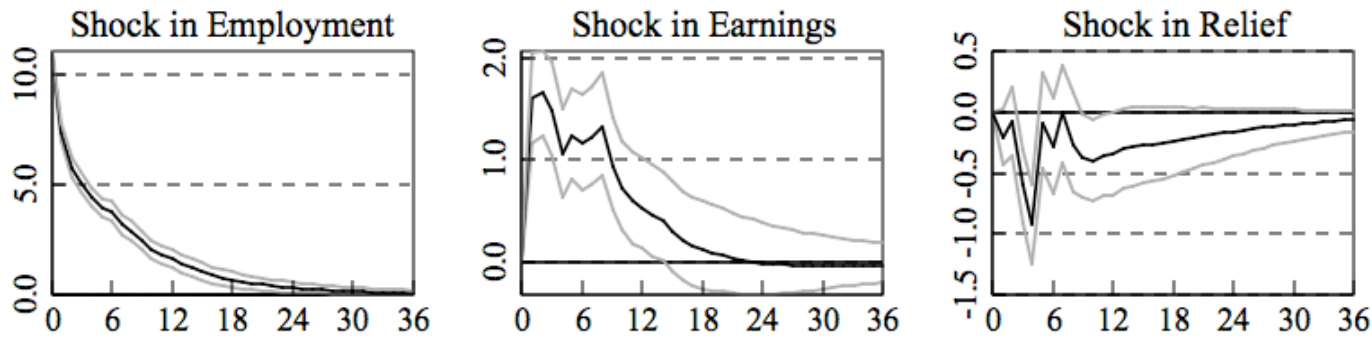

苋
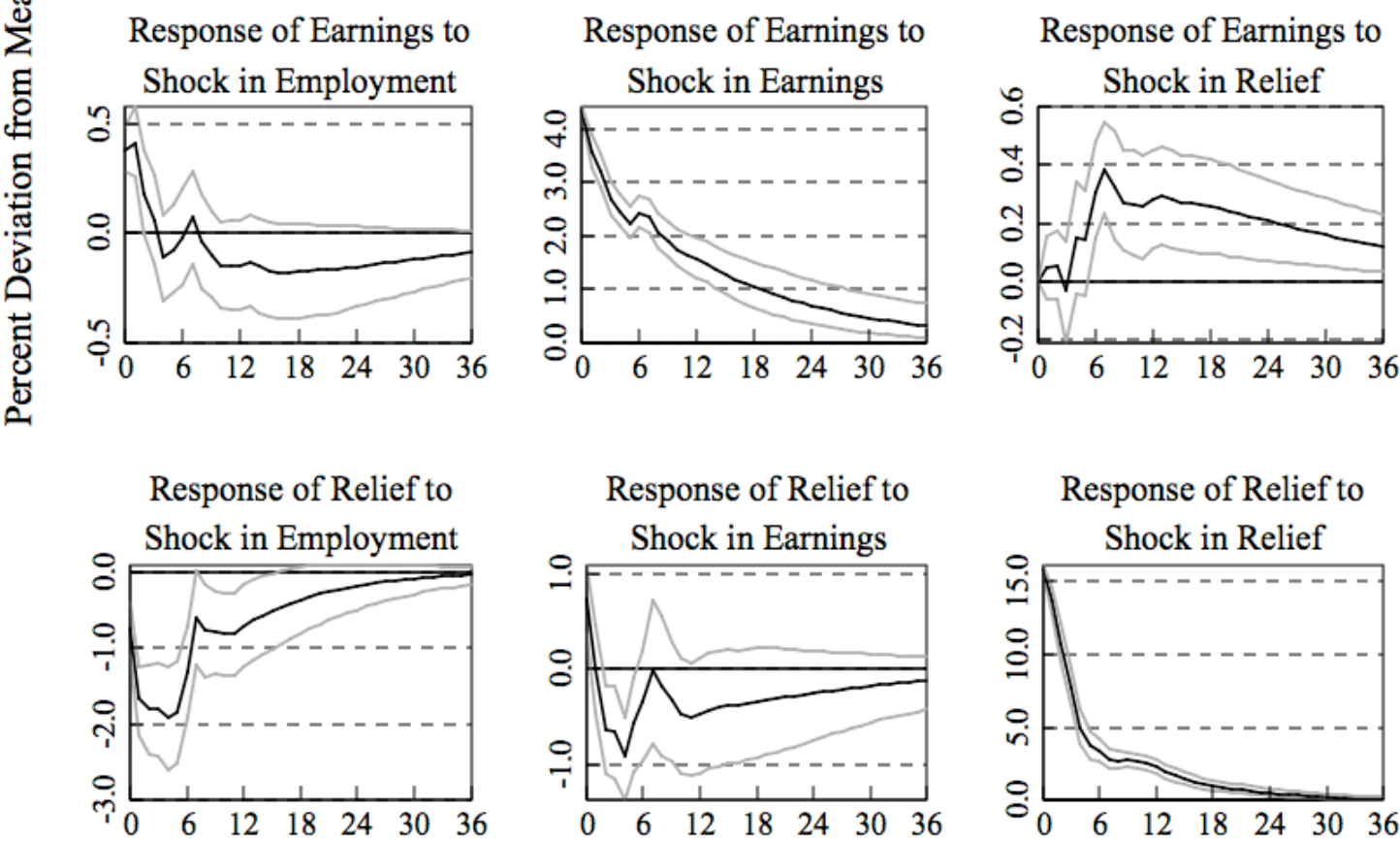

\section{Months after Shock}

Given these results we believe that the shape of our estimated IRFs capture the dynamic responses of employment and relief to one another during the Depression. The magnitude of those relationships, especially for employment should be viewed as rough estimates however. 
Figure D.4

Impulse Responses-Specification 1 Linked-Relative Index Under Measures Employment Changes

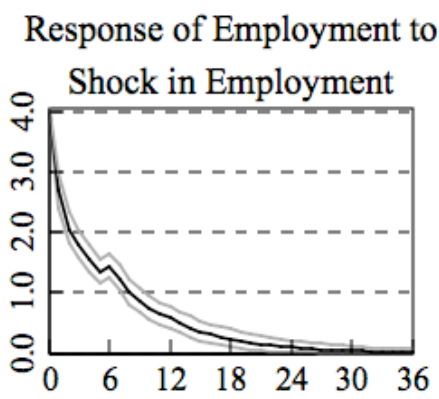

苋
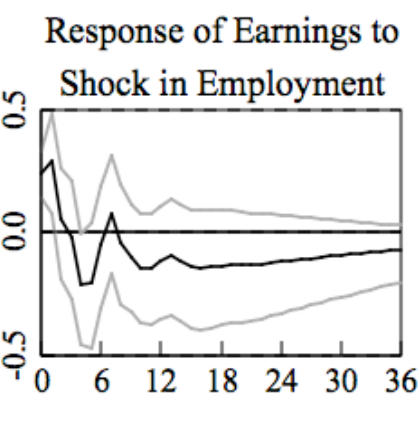

Response of Relief to

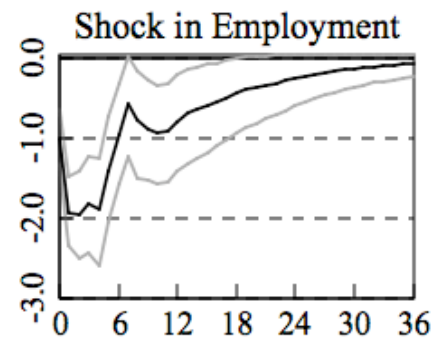

Response of Employment to

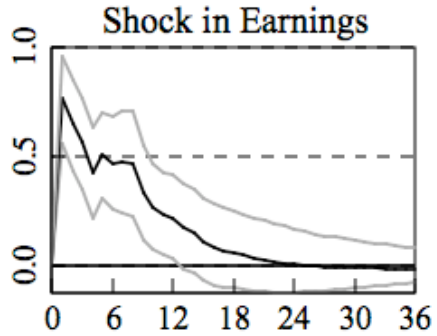

Response of Employment to
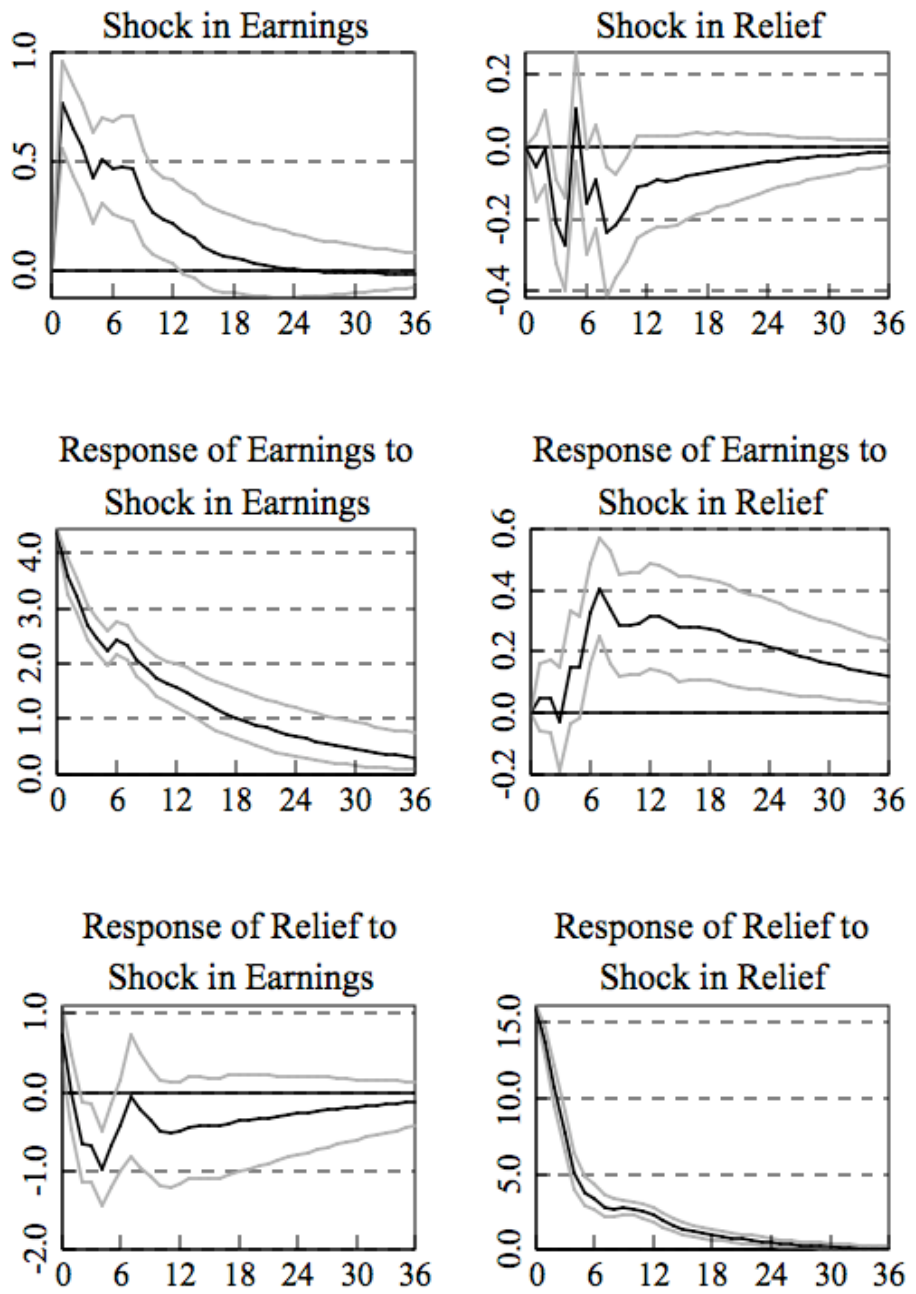

Response of Relief to

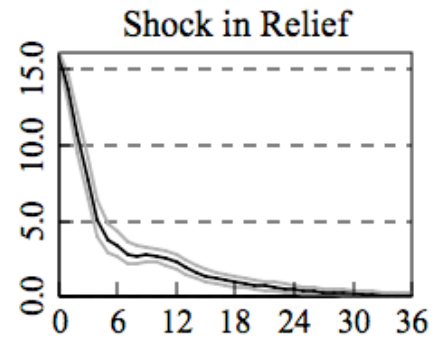

Months after Shock 


\section{References}

Aizcorbe Microbe, Ana. "Procyclical Labour Productivity, Increasing Returns to Labour and Labour Hoarding in U.S. Auto Assembly Plant Employment." Economic Journal, CII (1992): 860-73.

Arellano, M. and Stephen Bond. "Some Tests of Specification for Panel Data: Monte Carlo Evidence and an Application to Employment Equations." The Review of Economic Studies 58 (1991): 277-297.

Arnold, Sam and James C. Yocum, Ohio business data, 1926-1948, in charts \& tables, Ohio University State Bureau of Business Research: Columbus, 1949.

Bakke, E. Wight. The Unemployed Worker: A Study of the Task of Making a Living Without a Job. Hamden, CT: Archon Books, 1969 [c1940].

Blumberg, Barbara. The New Deal and the Unemployed: The View from New York City. Lewisburg, PA: Bucknell University Press, 1978.

Bordo, Michael, Christopher Erceg, and Charles Evans. "Money, Sticky Wages, and the Great Depression." American Economic Review 90 (December 2000): 1447-63.

Boustan, Leah Platt, Price Fishback, and Shawn Kantor. "The Effect of Internal Migration on Local Labor Markets: American Cities During the Great Depression.” Working paper. June 2007.

Brown, Josephine Chapin, Public Relief 1929-1939, Henry Holt \& Co.: New York, 1940.

Bernanke, Ben S. "Employment, Hours, and Earnings in the Depression: an analysis of eight manufacturing industries". The American Economic Review 76, no. 1 (1986): 82-109.

Boustan, Leah Platt, Price Fishback, and Shawn Kantor. "The Effect of Internal Migration on Local Labor Markets: American Cities During the Great Depression.” Presented at the DAE-NBER Program Meeting in Cambridge MA, March 4, 2006,

Brimhall, Dean M. "Alleged Labor Shortages During Periods of Large Government Spending for Relief." Draft of Internal Memo, April 30, 1937. WPA Records. Records of the Statistics Division, Entry 27.Box 40, National Archives II in College Park, Maryland.

Chari, V.V., Patrick Kehoe, and Ellen McGrattan. "Accounting for the Great Depression." American Economic Review Papers and Proceedings 92 (May 2002): 22-27.

Chari, V.V., Patrick Kehoe, and Ellen McGrattan. "Business Cycle Accounting.” Federal Reserve Bank of Minneapolis Research Department Working Paper 619. April 2002. 
Chari, V.V., Patrick Kehoe, and Ellen McGrattan. "Technical Appendix: Accounting for the Great Depression.” Federal Reserve Bank of Minneapolis Research Department Working Paper 619. March 2002.

Clarke, Jeanne Nienaber, Roosevelt's Warrior: Harold L. Ickes and the New Deal (Baltimore: Johns Hopkins University Press, 1996).

Cole, Harold and Lee Ohanian. "New Deal Policies and the Persistence of the Great Depression: A General Equilibrium Analysis.” Journal of Political Economy112, no. 4 (2004): 779816.

Cole, Harold and Lee Ohanian. "The Great Depression in the United States from a Neoclassical Perspective." Federal Reserve Bank of Minneapolis Quarterly Review 23 (Winter 1999): $2-24$.

Commonwealth of Massachusetts Department of Labor \& Industry, Time rates of Wages \& Hours of labor in Massachusetts, Annual Report on the Statistics of Labor, various issues.

Commonwealth of Pennsylvania, Labor \& Industry: quarterly bulletin, various issues.

Coyle, David Cushman. "The WPA—Loafers or Workers?” Reprint from Forum and Century. March 1939, no page numbers listed. WPA Records. Records of the Statistics Division, Entry 27.Box 40, National Archives II in College Park, Maryland.

Darby, Michael R. "Three and a half million U.S. Employees have been mislaid: or, an Explanation of Unemployment, 1934-1941." Journal of Political Economy 84, no. 1 (1976): 1-16.

Federal Emergency Relief Agency, Annual Report, Washington DC: Govt. Printing Office, 1940.

Federal Housing Administration, Annual Report, Washington DC: Govt. Printing Office, various years.

Federal Reserve Board. Federal Reserve Bulletin. Washington DC: Govt. Printing Office, various years.

Federal Security Agency, Public and Private Aid in 116 Urban Areas 1929-1938, Social Security Board.

Federal Works Agency Works Projects Administration, Report on Progress of the WPA Program, Washington DC: Govt. Printing Office, 1940.

Fishback, Price V., William C. Horrace, and Shawn Kantor. "The Impact of New Deal Expenditures on Mobility During the Great Depression," Explorations in Economic History, 43 (April 2006): 179-222. 
Fishback, Price V., William C. Horrace, and Shawn Kantor. "The Impact of New Deal Expenditures on Local Economic Activity: An Examination of Retail Sales, 1929-1939". Journal of Economic History, (March 2005): 36-71.

Fishback, Price V., Michael R. Haines and Shawn Kantor. "Births, Deaths, and New Deal Relief During the Depression”. Review of Economics and Statistics 89 (February 2007): 1-14.

Fishback, Price V., Shawn Kantor, and John Joseph Wallis, "Can the Three R's be Rehabilitated? A Comprehensive Analysis, Program by Program, County by County," Explorations in Economic History, 40 (July 2003), 278-307.

Fleck, Robert K. "The Marginal Effect of New Deal Relief Work on County-Level Unemployment Statistics." The Journal of Economic History, 59, no. 3 (1999a): 659687.

Fleck, Robert. K. The value of the vote: A model and test of the effects of turnout on distributive policy. Economic Inquiry, 37 (1999b): 609-23.

Hanes, Christopher L. "Changes in the Cyclical Behavior of Real Wage Rates, 1870-1990." Journal of Economic History, 56, 1996, pp. 837-861.

Hanes, Christopher. "Nominal Wage Rigidity and Industry Characteristics in the Downturns of 1893, 1929, and 1981." American Economic Review 90 (December 2000): 1432-46.

Howard, Donald S. The WPA and Federal Relief Policy, Russel Sage: New York, (1943).

Jensen, Richard. "The Causes and Cures of Unemployment in the Great Depression," Journal of Interdisciplinary History 19, (Spring 1989): 553-83.

Kahn, Lawrence M. and Stuart A. Low. "An Empirical Model of Employed Search, Unemployed Search, and Nonsearch," Journal of Human Resources 19, no. 1 (1984): 104-117.

Kesselman, Jonathan. "Work Relief Programs in the Great Depression." In Creating Jobs: Public Employment Programs and Wage Subsidies, edited by John L. Palmer. Washington, DC: Brookings Institution, 1978, pp. 153-229.

Krueger, Alan and Kenneth Fortson. "Do Markets Respond More to More Reliable Labor Market Data? A Test of Market Rationality." Journal of the European Economic Association 1 (June 2003); 931-957.

Larned, Abner E. Reports of the State Director on the Functions of the Various Federal Emergency Agencies in Alabama. Various dates between 1934 and 1937.Office of Government Reports, Record Group 44, National Archives II in College Park, Maryland. Entry 29, Box 415. Periodical Reports of State Directors, 1934-1938. 
Lebergott, Stanley. "Wage Rigidity' in the Depression: Concept or Phrase?," mimeo, Department of Economics, Wesleyan University, (Sept. 1989).

Love, Inessa and Lea Ziccino. "Financial Development and Dynamic Investment Behaviour: evidence from Panel VAR?", forthcoming in The Quarterly Review of Economics and Finance.

Maddala, G. S., and Wu, S. (1999). "A Comparative Study of Unit Root Tests with Panel Data and New Simple Test", Oxford Bulletin of Economics and Statistics, 61, 631-652

Margo, Robert A. "Interwar Unemployment in the United States: Evidence from the 1940 Census Sample." In Interwar Unemployment in International Perspective, edited by B. Eichenreen and T.J. Hatton, 325-52. Dordrecht: Kluwer Academic Publishers, 1988.

Margo, Robert A. "The Microeconomics of Depression Unemployment." Journal of Economic History 51 (June 1991): 333-341.

Margo, Robert A. "Employment and Unemployment in the 1930's." Journal of Economic Perspectives, 7, no. 2 (1993): 41-59.

McJimsey, G. T.. Harry Hopkins: Ally of the Poor and Defender of Democracy. Harvard University Press, Cambridge, MA, 1987.

McKean, Eugene and Harold Taylor. Public Works and Employment from the Local Government Point of View. A Report of the W. E. Upjohn Institute for Community Research. Chicago: Public Administration Service, 1955.

Millett, John D. The Works Progress Administration in New York City. Chicago: Public Administration Service, 1938.

Mortensen, Dale T. "Unemployment Insurance and Job Search Decisions," Industrial and Labor Relations Review 30, no. 4 (1977): 505-517.

Moulton, Harold G. "In Defense of the Longer Work Week," Annals of the American Academy of Political and Social Science, 184, 1936, pp. 68-71.

National Archives, Records of the Works Progress Administration, Record Group 69, film 5033.

National Resources Planning Board, Security, Work, and Relief Policies, Washington DC: Govt. printing Office, 1942.

Nelson, Charles R. and G. William Schwest. "Tests for Predictive Relationships between Time Series Variables: A Monte Carlo Investigation." Journal of the American Statistical Association, 77, (March 1982): 11-18. 
O’Brien, Anthony Patrick. "A Behavioral Explanation for Nominal Wage Rigidity during the Great Depression." Quarterly Journal of Economics, 104 (November 1989): 719-35.

Petree, John. Reports of the State Director on the Functions of the Various Federal Emergency Agencies in Alabama. Various dates between 1934 and 1937.Office of Government Reports, Record Group 44, National Archives II in College Park, Maryland. Entry 29, Box 392. Periodical Reports of State Directors, 1934-1938.

Pivetz, Timothy, Michael Searson, and James Spetzer. "Measuring Job and Establishment Flows With BLS Longitudinal Data." Monthly Labor Review (April 2001): 13-21.

Reading, Don C. "New Deal Activity and the States, 1933 to 1939." The Journal of Economic History, 33, no. 4 (1973): 792-810.

"State of Illinois Labor Department, Employment, Payrolls, and Average Weekly Earnings in Illinois, by City, Month, Year, various issues.

Schlesinger, Arthur. The Age of Roosevelt: The Coming of the New Deal (Boston: HoughtonMifflin, 1958).

Schwartz, Bonnie Fox. The Civil Works Administration, 1933-1934. Princeton, NJ: Princeton University Press, 1984.

Jason Scott Smith,_Building New Deal Liberalism: The Political Economy of Public Works, 1933-1956. New York: Cambridge University Press, 2006.

State of New York Industrial Commissioner, The Industrial Bulletin, Albany, New York, various issues.

State of Michigan Commissioner of Labor, Annual Report of the Bureau of Labor \& Industrial Statistics, various issues.

Sundstrom, William A. "Last Hired, First Fired? Unemployment and Urban Black Workers During the Great Depression." The Journal of Economic History, 51, no.2 (1992): 415429.

Sundstrom, William A. "Did the WPA Displace Private Employment? Evidence from the 1940 Census Manuscripts" Working paper. Santa Clara University. July 3, 1995.

Taylor, Jason. "Work-Sharing During the Great Depression: Did the "President's Reemployment Agreement Promote Reemployment?" Working paper at Central Michigan University 2008.

Taylor, Jason and George Selgin. "By Our Bootstraps: Origins and Effects of the High-Wage Doctrine and the Minimum Wage." Journal of Labor Research 20 (Fall 1999): 447-462. 
U.S. Bureau of the Census, Fifteenth Census of the United States, Washington DC: Govt. Printing Office, 1933.

U.S. Bureau of the Census, Biennial Census of Manufactures, 1935, Washington DC: Govt. Printing Office, 1936.

U.S. Bureau of the Census, Biennial Census of Manufactures, 1937, Washington DC: Govt. Printing Office, 1938.

U.S. Bureau of the Census, Sixteenth Census of the United States, Washington DC: Govt. Printing Office, 1942.

U.S. Bureau of Labor Statistics, Employment and Earnings, Washington DC: Govt. Printing Office, various issues.

U.S. Bureau of Labor Statistics, Employment and Payrolls, Washington DC: Govt. Printing Office, various issues.

U.S. Bureau of Labor Statistics, Monthly Labor Statistics, Washington DC: Govt. Printing Office, various issues.

Walker, Forrest. The Civil Works Administration: An Experiment in Federal Work Relief, 19331934. New York: Garland Publishing, 1979.

Walker, L.C. "The Share-the-Work Movement," Annals of the American Academy of Political and Social Science, 165, 1933, pp. 13-19.

Wallis, John Joseph, "Employment in the Great Depression: new data and hypothesis." Explorations in Economic History 26, (Jan. 1989): 45-72.

Wallis, John Joseph, and Daniel K. Benjamin "Private Employment and Public during the Great Depression." Department of Economics, University of Maryland working paper, (1989).

Wallis, John Joseph, "Employment, Politics, and Economic Recovery during the Great Depression." The Review of Economics and Statistics 69, (Aug. 1987): 516-520.

Wallis, John Joseph, and Daniel K. Benjamin "Public Relief and Private Employment in the Great Depression." The Journal of Economic History 41, no. 2 (1981): 97-102.

Wallis, John Joseph, Price Fishback and Shawn Kantor. "Politics, Relief, and Reform: Roosevelt's Efforts to Control Corruption and Political Manipulation During the New Deal." Corruption and Reform: Lessons from America's Economic History, edited by Edward Glaeser and Claudia Goldin. Chicago: University of Chicago Press, 2006, pp. 343-372.

Williams, Edward A. Federal Aid for Relief. New York: AMS Press, 1939. 
Wisconsin Industrial Commission, Wisconsin Labor Market, Madison, Wisconsin, various issues.

Wood, Lorenzo K. Report of State Director on the Functions of the Various Federal Emergency Agencies for Kentucky. Office of Government Reports, Record Group 44, National Archives, Entry 29, Box 407. Periodical Reports of State Directors, 1934-1938.

Works Progress Administration. Series of Internal Memos on Labor Shortages with no names attached. 1937. WPA Records. Records of the Statistics Division, Entry 27, Box 40, National Archives II in College Park, Maryland.

Wright, Gavin. "The Political Economy Of New Deal Spending: An Econometric Analysis." Review of Economics and Statistics 56 (1974), 30-38.

Zellner, Arnold and Franz Palm. "Time Series Analysis and Simultaneous Equation Econometric Models." Journal of Econometrics, 2, (May 1974): 17-54. 